\title{
Economic Dislocation and Recovery in Lebanon
}

Sena Eken, Paul Cashin, S. Nuri Erbaș, Jose Martelino, and Adnan Mazarei

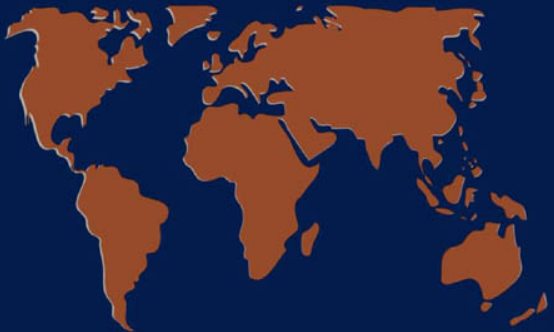




\section{Economic Dislocation and Recovery in Lebanon}

Sena Eken, Paul Cashin, S. Nuri Erbaș, Jose Martelino, and Adnan Mazarei 
() 1995 International Monetary Fund

\section{Library of Congress Cataloging-in-Publication Data}

Economic dislocation and recovery in Lebanon / Sena Eken ... [et al.].

p. $\quad \mathrm{cm}$. - (Occasional Papers, ISSN 0251-6365; 120)

Includes bibliographical references.

ISBN 1-55775-459-4: $\$ 15.00$

1. Lebanon-Economic conditions. 2. Lebanon-Economic policy,

3. Lebanon-History-Civil War, 1975- -Economic aspects.

I. Eken, Sena II. Series: Occasional paper (International Monetary

Fund); no. 120.

HC415.24.E26 1995

$330.95692^{\prime} 044-\mathrm{dc} 20$

CIP

Price: US $\$ 15.00$

(US $\$ 12.00$ to full-time faculty members and students at universities and colleges)

Please send orders to:

International Monetary Fund, Publication Services 700 19th Street, N.W., Washington, D.C. 20431, U.S.A.

Tel.: (202) 623-7430 Telefax: (202) 623-7201

Internet: publications@imf.org

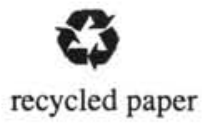




\section{Contents}

Page

Preface vii

1 Introduction 1

II Some Economic Consequences of the Civil War 3

Consequences of the War for Output 3

\begin{tabular}{ll}
\hline How Fast Can Lebanon Recover? & 6 \\
\hline Does It Matter for Growth What Type of Capital Was Lost? & 9 \\
\hline
\end{tabular}

III Impact of the War on Budgetary Performance, Structural Weaknesses of the Budget, and Reform Measures II

Overview of Fiscal Performance During and After the War 11

\begin{tabular}{ll}
\hline Structural Weaknesses of the Budget & 15
\end{tabular}

\begin{tabular}{lr}
\hline Measures to Address the Structural Weaknesses & 17 \\
\hline
\end{tabular}

IV Currency Substitution and Dollarization 19

Origins and Extent of Dollarization 19

\begin{tabular}{ll}
\hline Capital Flight and Repatriation & 20 \\
\hline Advanages and
\end{tabular}

\begin{tabular}{ll}
\hline Advantages and Disadvantages of Dollarization & 22 \\
\hline
\end{tabular}

Policies to Achieve, and Consequences of, De-Dollarization 23

V Estimating Money Demand in Lebanon $\quad 25$

Dollarization and the Definition of Money 25

\begin{tabular}{ll}
\hline Behavior of Velocity & 25 \\
\hline
\end{tabular}

\begin{tabular}{ll}
\hline Specifications of Money Demand & 26 \\
\hline
\end{tabular}

\begin{tabular}{ll}
\hline Unit Root Tests for Stationarity & 27 \\
\hline
\end{tabular}

Money Demand: Cointegration Results and Policy Implications 28

\begin{tabular}{ll}
\hline Conclusions & 30 \\
\hline
\end{tabular}

VI Exchange Rate Developments and Their Relationship to Inflation 32

Evolution of the Exchange Rate 32

Long-Term Relationship Between Exchange Rate Movements

and Inflation 36

Short-Term Dynamics of Inflation and the Exchange Rate and the

Two-Way Relationship Between Them

\section{Text Tables}

\section{Section}

II 1. Measures of GDP

2. Population and GDP 
3. Convergence of Actual to Steady-State Real Per Capita Incomes 9

III 4. Summary of Public Sector Operations (In billions of Lebanese pounds) 12

5. Summary of Public Sector Operations (In percent of GDP) 13

6. Summary of Public Sector Operations (In percent of total) 14

7. Fiscal Indicators for Selected Middle Eastern Countries 16

\begin{tabular}{ll} 
IV & Currency Substitution \\
\hline
\end{tabular}

\begin{tabular}{ll} 
9. Average Inflation Tax & 23 \\
\hline
\end{tabular}

\begin{tabular}{lll} 
V 10. Phillips-Perron Tests for Stationarity, 1964-93 & 28 \\
\hline
\end{tabular}

\begin{tabular}{lll}
\hline $\mathbf{V}$ & 11. Exchange Rate Indices and Inflation & 33 \\
\hline
\end{tabular}

\begin{tabular}{lr} 
12. Legal Minimum Wages & 36 \\
\hline
\end{tabular}

13. Regressions of the Differential Between Lebanese and U.S. Inflation Rates on Changes in the LL/US\$ Exchange Rate $\quad 38$

14. Dickey-Fuller Unit Root Tests, 1951-93 38

\begin{tabular}{ll}
\hline 15. Johansen Cointegration Test, 1975-93 & 39 \\
\hline
\end{tabular}

16. Dickey-Fuller Unit Root Tests, 1989-92 39

17. Johansen Cointegration Test, 1989-92 40

\section{Charts}

\section{Section}

II 1. GDP and Population Indices

2. Per Capita Real GDP, 1964-2010

III 3. GDP and Fiscal Performance 11

\begin{tabular}{ll}
\hline IV 4. Currency Substitution and Dollarization & 21 \\
\hline
\end{tabular}

\begin{tabular}{lr} 
5. Dollarization and Exchange Rate Movements & 21 \\
\hline
\end{tabular}

6. Real and Nominal Cross-Border Deposits 21

7. Cross-Border Deposits (As percent of foreign exchange reserves minus gold)

8. Cross-Border Deposits (As percent of $M 2$, including foreign currency deposits)

v 9. Velocity of Monetary Aggregates

10. Monetary Aggregates 26

\begin{tabular}{lr}
11. Composition of Total Liquidity & 27 \\
\hline
\end{tabular}

VI 12. Volatility of the Lebanese Pound/U.S. Dollar Exchange Rate $\quad 34$

13. Real and Nominal Effective Exchange Rates, 1964-93 35

14. Real and Nominal Effective Exchange Rates, 1989-93 35

15. Lebanon and Selected Other Countries: Nominal Effective Exchange Rates

16. Lebanon and Selected Other Countries: Real Effective Exchange Rates $\quad 37$

\begin{tabular}{ll}
\hline 17. Price Level and Exchange Rates, 1951-80 & 37 \\
\hline
\end{tabular}

\begin{tabular}{ll}
\hline 18. Price Level and Exchange Rates, 1975-93 & 37 \\
\hline
\end{tabular}

\begin{tabular}{ll}
\hline 19. Price Level and Exchange Rates, 1989-94 & 38 \\
\hline
\end{tabular}

\section{Appendices}

I Exchange and Trade System $\quad 42$

II Statistical Tables $\quad \mathbf{4 4}$

A1. Selected Social, Economic, and Financial Indicators 44

\begin{tabular}{lll}
\hline A2. & Selected Indicators of Sectoral Economic Activity & 46 \\
\hline A3. Consumer
\end{tabular}

\begin{tabular}{lll}
\hline A3. & Consumer Price Indices & 46
\end{tabular}

\begin{tabular}{lll}
\hline A4. & Summary of Central Government Operations & 47 \\
\hline
\end{tabular}

\begin{tabular}{lll}
\hline A5. & Treasury Bills in Circulation & 48 \\
\hline
\end{tabular}

\begin{tabular}{lll}
\hline A6. & Bank of Lebanon Balance Sheet & 49 \\
\hline
\end{tabular}

\begin{tabular}{ll}
\hline A7. Commercial Banks'Balance Sheet & 50 \\
\hline
\end{tabular}

\begin{tabular}{llr}
\hline A8. & Monetary Survey & 51 \\
\hline
\end{tabular} 
A9. Factors Affecting Lebanese Pound Component of Domestic Liquidity 51

A10. Distribution of Residents' Monetary Assets $\quad 52$

A11. Commercial Banks' Claims on Private Sector Classified by

Economic Activity

\begin{tabular}{ll}
\hline A12. Discounts and Yields on Three-Month Treasury Bills & 53 \\
\hline
\end{tabular}

A13. Commercial Bank Interest Rates on Lebanese

Pound Transactions, 1989-94

\begin{tabular}{lc}
\hline A14. Summary of the Balance of Payments & 55 \\
\hline
\end{tabular}

\begin{tabular}{lr}
\hline A15. Composition of Industrial Exports & 56 \\
\hline
\end{tabular}

\begin{tabular}{lc}
\hline A16. Destination of Exports & 56 \\
\hline
\end{tabular}

\begin{tabular}{lr}
\hline A17. Source of Imports & 57 \\
\hline
\end{tabular}

\begin{tabular}{lr}
\hline A18. Exchange Rate of the Lebanese Pound & 58 \\
\hline
\end{tabular}

A19. Nominal and Real Effective Exchange Rates of the Lebanese Pound $\quad 59$

The following symbols have been used throughout this paper:

... to indicate that data are not available;

- to indicate that the figure is zero or less than half the final digit shown, or that the item does not exist;

- between years or months (e.g., 1991-92 or January-June) to indicate the years or months covered, including the beginning and ending years or months;

/ between years (e.g., 1991/92) to indicate a crop or fiscal (financial) year.

"Billion" means a thousand million.

Minor discrepancies between constituent figures and totals are due to rounding.

The term "country," as used in this paper, does not in all cases refer to a territorial entity that is a state as understood by international law and practice; the term also covers some territorial entities that are not states, but for which statistical data are maintained and provided internationally on a separate and independent basis. 
This page intentionally left blank

CInternational Monetary Fund. Not for Redistribution 


\section{Preface}

This Occasional Paper is based on studies that were prepared in connection with the 1994 Article IV consultation with Lebanon. The authors are grateful to the Lebanese authorities for their cooperation in this project. They would like to thank Saïd H. Hitti for his support and guidance in the production of the studies. They also thank Pierre-Richard Agenor, Toufic Gaspard, Nadeem Haque, Malcolm Knight, and John McDermott for their valuable comments, Ilse-Marie Fayad for assistance in preparing the charts, Susan E. Jones for secretarial assistance, and Elisa Diehl of the External Relations Department for editing the final paper and coordinating its production. The views expressed, as well as any errors, are solely the responsibility of the authors and do not necessarily reflect the opinions of the Lebanese authorities, the IMF, or its Executive Directors. 
This page intentionally left blank

(C) International Monetary Fund. Not for Redistribution 


\section{Introduction}

n the ten years prior to 1975, the Lebanese economy was one of the most dynamic in the Middle East region. It was characterized by low inflation, high rates of economic growth, large balance of payments surpluses, small fiscal deficits, and a floating, stable, and fully convertible domestic currency. Regulations impinging on the functioning of markets for goods and services, labor, capital, and trade were limited, and tax burdens were light in comparison with other countries at a similar stage of development. Furthermore, Lebanon had an important role as the key economic intermediary between the developed economies of Europe and the developing economies of the Middle East. Because of this combination of a stable macroeconomic environment, liberal economics, and its role as regional intermediary, Lebanon enjoyed a strong comparative advantage in the services sector of its economy, particularly in banking and finance, tourism, insurance, and trade-related services.

Lebanon's civil war, which started in 1975 and spanned 15 years, exacted a heavy toll in human and material terms and caused fundamental changes in the economy. The economy suffered from the destruction of infrastructure and industrial facilities, while the reluctance to invest resulted in the obsolescence of remaining production capacity. Moreover, the flow of goods and factors of production in Lebanon was disrupted as a result of the fragmentation of the country. There was mass emigration, with an accompanying loss in professional and entrepreneurial skills. The emigration of workers was accompanied by a flight of capital, and Lebanon's access to flows of foreign capital was much reduced. Meanwhile, Lebanon's public finances deteriorated significantly owing to the lack of central government authority in the country and the consequent inability of the authorities to collect revenues while continuing to provide a minimum of public services. Large fiscal deficits were financed primarily through the banking system. The consequent rapid growth in liquidity compared with economic activity, and the erosion of private sector confidence, led to continuous pressures on the Lebanese pound in the exchange market, heightened inflationary pressures, and resulted in high levels of currency substitution. Furthermore, during the war years the banking system was weakened considerably and Lebanon's role as a regional intermediary was greatly reduced. Nevertheless, Lebanon continued to maintain an exchange and trade system that was almost entirely free of restrictions on payments and transfers for current and capital transactions.

The basis for a peaceful settlement to the civil war was provided by the 1989 Taïf Accord for National Reconciliation, negotiated under the aegis of the Arab League. Following the accord, government authority was gradually restored, and hostilities came to an end in 1990. Subsequently, the authorities began the difficult task of simultaneous economic stabilization and confidence building on the one hand, and postwar reconstruction and development on the other, to ensure a sustainable recovery of the dislocated Lebanese economy. Confidence was restored in the last quarter of 1992 following the completion of parliamentary elections, the first in twenty years, and the installation of the new government.

In 1993, improved political stability, increased confidence, and an effective adjustment effort spurred favorable macroeconomic developments. Real GDP picked up, inflation decelerated sharply, foreign exchange reserves were built up to a comfortable level, and the exchange rate was stabilized. However, the lack of adequate infrastructure, a weak institutional framework, and shortages of human capital continued to constrain overall economic recovery. In the circumstances, the authorities aim at accelerating the reconstruction and rehabilitation program in the period ahead while strengthening the macroeconomic stance.

This paper provides background information on the Lebanese economy, based on an analysis of the economic consequences of the war, and discusses several issues that will be central to Lebanon's prospects for recovery. The analysis is based, for the most part, on economic developments through the end of 1993. The second section of the paper examines the economic costs of the war and the effects of the drastic warinduced shrinkage of real output on the potential growth path of the economy. The third section reviews the impact of the civil war on Lebanon's government finances, highlighting the initial collapse in revenue, and discusses the authorities' postwar efforts to rein in 


\section{INTRODUCTION}

the run of war-induced deficits. The fourth section analyzes the reasons for and consequences of the largescale dollarization in Lebanon, the rationale for capital flight and the consequences of its return, and appropriate policies to de-dollarize the economy. The fifth section of the paper presents estimates of money demand in Lebanon, in an effort to determine which monetary aggregate gives the authorities the best scope for influencing future macroeconomic developments. The sixth section reviews historical developments in the Lebanese exchange rate system and examines the strength of the empirical relationship between movements in the exchange rate and the rate of Lebanese inflation during 1951-93. 


\section{Some Economic Consequences of the Civil War}

\begin{abstract}
$T$ his section examines the economic costs of the 1975-90 Lebanese civil war and its effects on the country's prospects for growth. The first subsection measures the value of output forgone owing to the war, and the second examines the implications for the path of future Lebanese growth of the drastic war-induced shrinkage of real output. The final subsection analyzes the growth consequences of the wartime destruction of capital, which yielded cross-sectoral imbalances in the stocks of physical and human capital. Four key conclusions arise from this work. First, the loss of output during 1975-93 is at least LL 98 billion at constant 1974 prices, or about 24 times the value of Lebanon's 1993 real GDP (at constant 1974 prices). Second, the length of time it will take Lebanon to reattain its prewar (1974) real per capita output level is partly contingent on the magnitude of the gap between 1993 measured and potential output and on how quickly this gap can be closed. Assuming that half this gap is closed in 1994 and that real per capita GDP will grow by 6 percent a year thereafter, Lebanon could close the remaining gap during the year 2000. Third, the transition from Lebanon's low postwar real per capita income level (estimated for 1993 to be about 48 percent of its 1974 value) to its steady-state level is likely to take several generations to complete, although three-fourths of the initial gap could be closed by about 2023 if high growth rates are achieved. Fourth, given that the civil war destroyed relatively more of Lebanon's stock of physical capital than of its human capital, the potential exists for Lebanon's real per capita income to approach its steady-state level at an even more rapid rate than that given above.
\end{abstract}

\section{Consequences of the War for Output}

One useful measure of the direct economic cost of the civil war is the consequent loss of potential output. An estimate of the cumulative loss of output over 1975-93 can be obtained by valuing the deviations of actual real Lebanese GDP from trend real GDP that it is assumed would have been attained in the absence of the war. Saïdi (1984a) documents the relatively rapid rate of growth of the Lebanese economy during
1964-74, calculating a trend rate of real output growth of 5.95 percent a year over this period. In this analysis, a range of possible trend growth rates is utilized.

Official data on national accounts and prices covering the entire period 1964-93 are not available. The consumer price index used here is a linked index (for 1964-87) of the Beirut Chamber of Commerce and Industry and (for 1988-93) the index prepared by the Consultation and Research Institute for the Trade Union Confederation. Nominal GDP data for 1964-74 are from official sources (Direction Centrale de la Statistique), taken here from Saïdi (1984a). The GDP data for 1975-82 are taken from Bank of Lebanon (BDL)/IMF staff estimates. The GDP estimates for 1983-86 are interpolations, based on indices of electricity production and imports. ${ }^{1}$ The GDP figure for 1987 is that of Gaspard (1989). GDP estimates for 1988-93 are taken from IMF staff and World Bank calculations, based on a United Nations Development Program study on extrapolations of GDP for 1989-90. It is also important to recognize that during the war years the decline in GDP was most likely more than that of GNP, because of large net factor incomes from abroad.

Values for real Lebanese GDP for 1964-93, derived from a series for nominal GDP and using the consumer price index $(1974=100)$ as the deflator, are presented below (Table 1). The resulting real GDP series reveals large falls in economic activity during the banking crisis of 1967 and the war years of 1975-76, 1982, 1986, and $1988-90 .^{2}$ Calculations using the data contained in Table 1 yield an average annual rate of growth of Lebanon's real GDP of 5.8 percent during 1964-74, which compares with a rate of minus 2.7 percent for 1975-93; in real per capita terms, the relevant growth rates are 3.3 percent and minus 3.0 percent, respectively.

A range of trend annual growth rates for the period $1975-93$ is used to calculate the cost of the war in terms of forgone Lebanese output: the 5.95 percent rate of Saïdi (1984a), 4 percent, and 2 percent (Table 1). Of

${ }^{1}$ GDP estimates based on indices of imports could be biased downward in years when sharp exchange rate depreciations reduced the demand for imports.

2These falls are also reflected in declines in the volume of electricity production in 1976, 1981, 1984, 1986, and 1989-90 (Table 1). 
Table I. Measures of GDP (In millions of Lebanese pounds)

Percentage Deviation of Actual GDP from Trend GDP. Using Trend Growth Rates

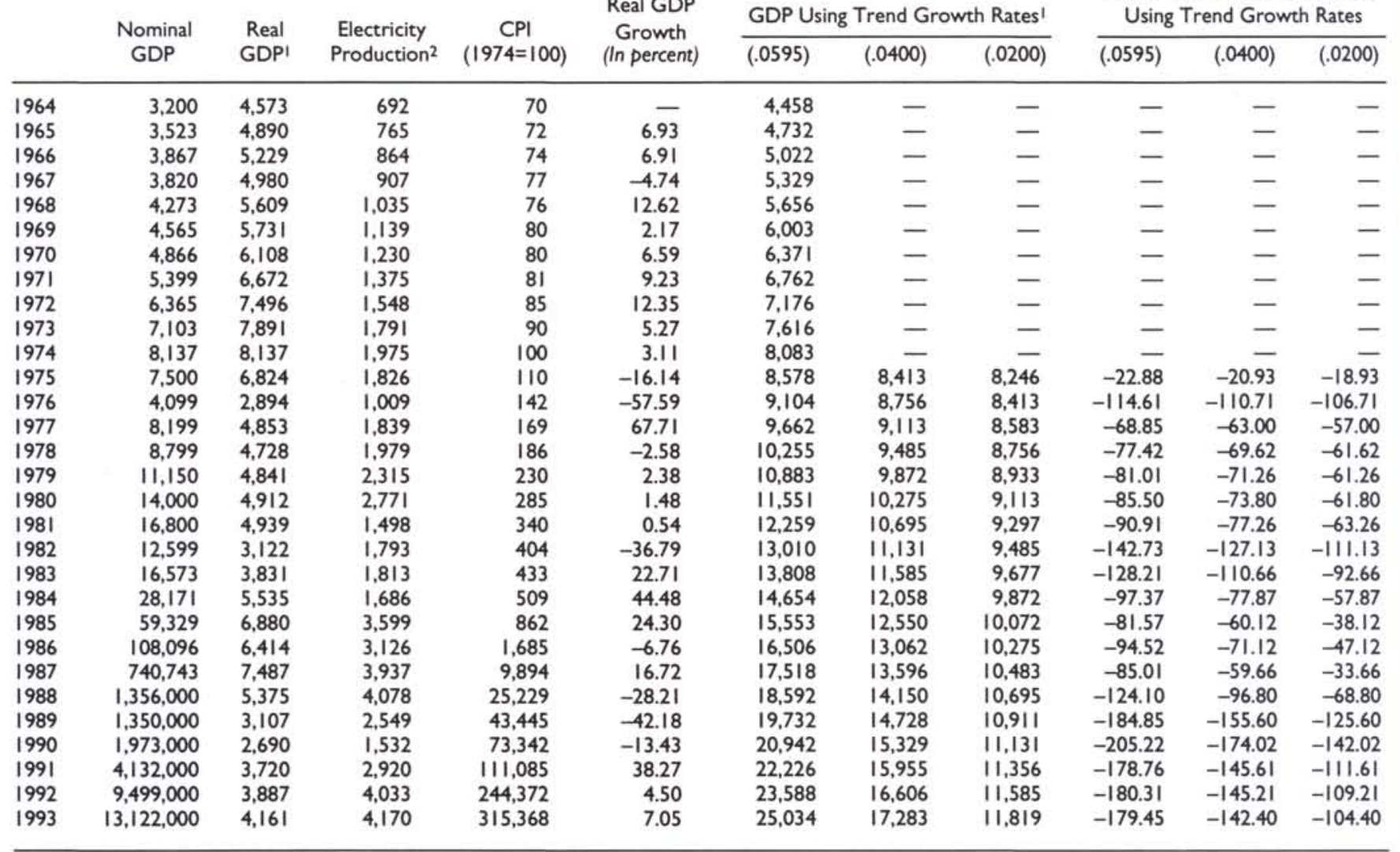

Sources: International Monetary Fund, International Financial Stotistics; Bank of Lebanon; and IMF staff estimates.

IIn millions of real (constant 1974) Lebanese pounds.

In millions of kilowatt hours.

course, growth in Lebanese output after 1975 may not have continued at its prewar rate of 5.95 percent a year, and for this reason the two alternative growth rates are used. As noted by Saïdi (1984a), Lebanon could have followed the experience in the 1970s and 1980s of industrial countries and shown a decline in average rates of growth of output. However, it could also be argued that in the absence of war, developments in Lebanon would have been strongly influenced by the post-1974 prosperity of the oil producing countries of the region, the strong flow of remittances from Lebanese abroad, and large-scale inflows of Arab capital.

The cumulative sums of the value of the 1975-93 deviations from trend-for trend growth rates of 5.95 percent, 4 percent, and 2 percent-are (in constant 1974 Lebanese pounds): LL 203,257 million,
LL 144,444 million, and LL 98,503 million, respectively. Using the most conservative trend growth rate of 2 percent, such an amount represents about 12 times the value of Lebanese GDP in 1974, or about 24 times the value of real 1993 Lebanese GDP (in constant 1974 prices). The equivalent results for the 5.95 percent trend growth rate are about 25 and 50 times the value of 1974 and real 1993 output, respectively. All of the above calculations are likely to underestimate the true economic cost of the war because they fail to account for such indirect costs as the value of loss of life, the cost of disabilities, and accretions in human capital forgone owing to the war, all of which were undoubtedly considerable. ${ }^{3}$

\footnotetext{
${ }^{3}$ While the loss of life has been estimated at over 150,000 , casualties were more than double that number (United Nations (1991)).
} 
Table 2. Population and GDP

\begin{tabular}{|c|c|c|c|c|c|}
\hline & $\begin{array}{l}\text { Real } \\
\text { GDP }\end{array}$ & $\begin{array}{c}\text { Real Per } \\
\text { Capita GDP }\end{array}$ & Population & \multirow{2}{*}{$\begin{array}{c}\text { Real Per } \\
\text { Capita GDP } \\
\text { (In 1974 Lebanese pounds) }\end{array}$} & \multirow{2}{*}{$\begin{array}{l}\begin{array}{l}\text { Growth of Real } \\
\text { Per Capita GDP }\end{array} \\
\text { (In percent) }\end{array}$} \\
\hline & \multicolumn{3}{|c|}{ (Indices, $1974=100$ ) } & & \\
\hline 1964 & 56.20 & 72.04 & 78.02 & $2,147.13$ & - \\
\hline 1965 & 60.10 & 76.31 & 78.75 & $2,274.58$ & 5.94 \\
\hline 1966 & 64.26 & 79.37 & 80.95 & $2,365.84$ & 4.01 \\
\hline 1967 & 61.21 & 73.61 & 83.15 & $2,194.03$ & -7.26 \\
\hline 1968 & 68.93 & 80.42 & 85.71 & $2,397.04$ & 9.25 \\
\hline 1969 & 70.43 & 80.11 & 87.91 & $2,387.75$ & -0.39 \\
\hline 1970 & 75.07 & 82.97 & 90.48 & $2,473.06$ & 3.57 \\
\hline 1971 & 82.00 & 88.48 & 92.67 & $2,637.16$ & 6.64 \\
\hline 1972 & 92.12 & 96.73 & 95.24 & $2,883.14$ & 9.33 \\
\hline 1973 & 96.98 & 99.53 & 97.44 & $2,966.67$ & 2.90 \\
\hline 1974 & 100.00 & 100.00 & 100.00 & $2,980.59$ & 0.47 \\
\hline 1975 & 83.86 & 82.65 & 101.47 & $2,463.45$ & -17.35 \\
\hline 1976 & 35.57 & 35.05 & 101.47 & $1,044.75$ & -57.59 \\
\hline 1977 & 59.65 & 59.00 & 101.10 & I,758.5। & 68.32 \\
\hline 1978 & 58.11 & 58.11 & 100.00 & $1,732.00$ & -1.51 \\
\hline 1979 & 59.49 & 60.15 & 98.90 & $1,792.92$ & 3.52 \\
\hline 1980 & 60.37 & 61.73 & 97.80 & $1,839.87$ & 2.62 \\
\hline 1981 & 60.70 & 62.29 & 97.44 & I,856.7| & 0.92 \\
\hline 1982 & 38.37 & 39.38 & 97.44 & $1,173.70$ & -36.79 \\
\hline 1983 & 47.08 & 48.32 & 97.44 & I,440.22 & 22.71 \\
\hline 1984 & 68.02 & 69.55 & 97.80 & $2,072.98$ & 43.93 \\
\hline 1985 & 84.55 & 86.45 & 97.80 & $2,576.62$ & 24.30 \\
\hline 1986 & 78.83 & 80.60 & 97.80 & $2,402.40$ & -6.76 \\
\hline 1987 & 92.01 & 93.73 & 98.17 & $2,793.61$ & 16.28 \\
\hline 1988 & 66.05 & 67.03 & 98.53 & I,998.02 & -28.48 \\
\hline 1989 & 38.19 & 38.47 & 99.27 & $1,146.63$ & -42.61 \\
\hline 1990 & 33.06 & 32.94 & 100.37 & 981.80 & -14.38 \\
\hline 1991 & 45.71 & 44.89 & 101.83 & I,338.0I & 36.28 \\
\hline 1992 & 47.77 & 45.92 & 104.03 & $1,368.70$ & 2.29 \\
\hline 1993 & 51.14 & 48.10 & 106.32 & $1,433.60$ & 4.74 \\
\hline
\end{tabular}

Sources: Bank of Lebanon; International Monetary Fund, International Financial Statistics; and IMF staff estimates.

Table 2 presents an index of real GDP, which reveals a steady increase in real output up to 1974 , then a rapid decline in activity in 1976, to only 36 percent of its 1974 level. Interestingly, by 1987 output had recovered to 92 percent of its 1974 level, only to fall again with the active resumption of hostilities to a period low of 33 percent of the 1974 level in 1990, gradually rising thereafter to reach 51 percent of its 1974 level by 1993. ${ }^{4}$ Despite the resilience of the Lebanese economy, real output has yet to recover from the hostilities that began in 1975. A similar story exists for real per capita GDP, with net emigration during the 1980 s raising real per capita GDP slightly during those years, and net immigration during the 1990s lowering real per capita GDP slightly, both relative to the index of real GDP. The index of Lebanese population $(1974=100)$ shows

${ }^{4}$ The strong recovery in real GDP in 1987 , and its subsequent fall in 1988, could partly reflect the different methodology used for estimating the 1987 GDP. that by 1993 Lebanon's population had grown to more than 6 percent above its 1974 level. All three series are depicted in Chart 1.

As noted by Saïdi (1986), the chief determinants of Lebanon's failure to retain its real prewar output levels were (1) a large decline in investment, owing to the war-induced heightening of risk, which drastically slowed productivity growth rates; (2) the dislocation of goods and labor markets; and (3) the widespread destruction of physical capital stocks and large-scale emigration of those Lebanese endowed with relatively high levels of human capital. The total damage to physical assets during the war period has been estimated by the United Nations (1991) at $\$ 25$ billion. In addition, the World Bank (1993) estimates that, during 1975-90, some 200,000 professional and skilled Lebanese sought employment in other countries. This is 7.33 percent of the 1974 population and is reflected in the population index of Table 2. The 1989 signing of the Taif Accord for National Reconciliation provided the catalyst for an 


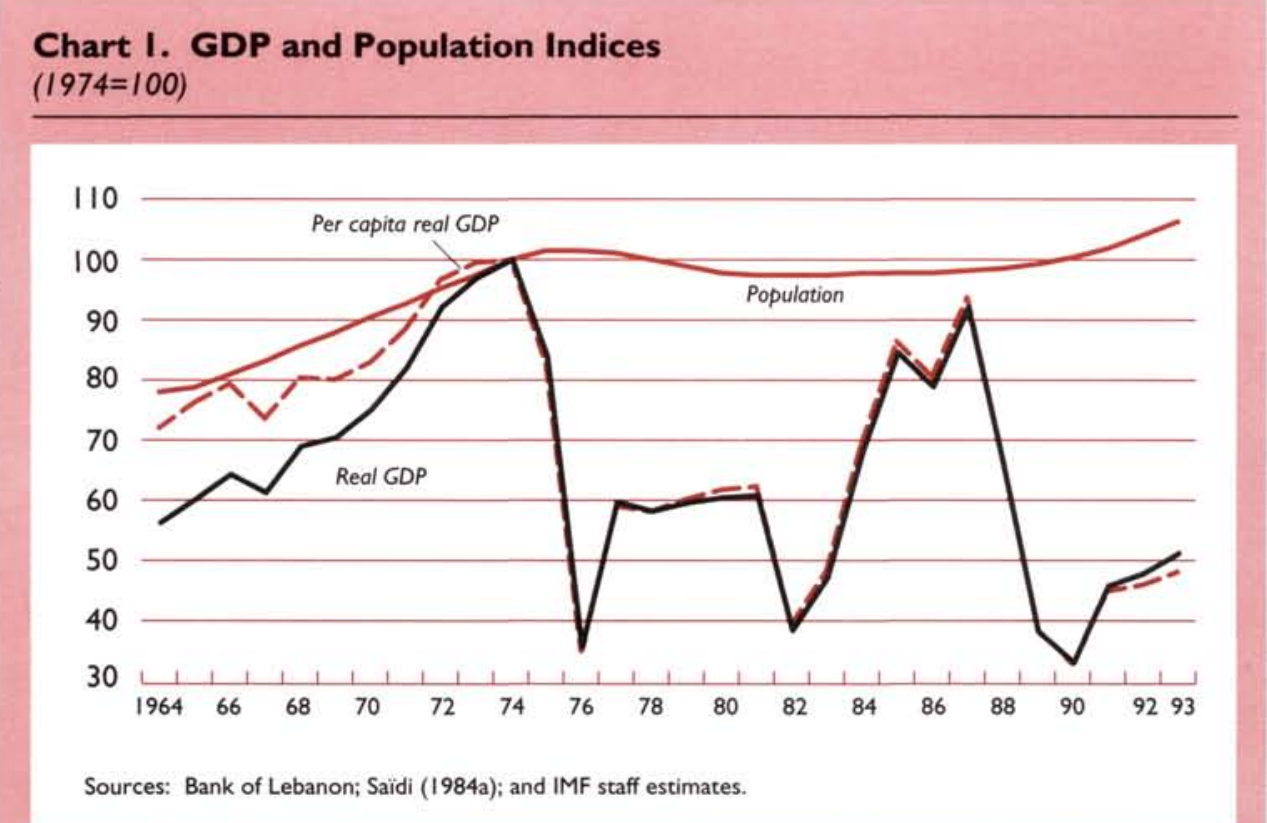

end to hostilities during 1990 and the beginning of efforts to reconstruct the Lebanese economy.

\section{How Fast Can Lebanon Recover?}

According to the above estimates, Lebanese real per capita incomes at the end of the 1980s had been reduced to about one-third their level of 1974 as a direct result of the civil war (Table 2). This raises the question of how long it will take Lebanon not only to recover to its 1974 level of per capita income, but also to attain the steady-state (or long-run) real income level it would have realized in the absence of the war. In the analysis below, this question is addressed using the conventional framework of neoclassical growth theory (Solow (1956) and Swan (1956)).

Lebanese real per capita income (in constant 1974 Lebanese pounds) in 1974 was LL 2,981 but, by 1993 , had fallen to LL 1,434. Assuming a constant rate of growth of the Lebanese population after 1993 of 2 percent a year (largely driven by high net immigration as the growing economy attracts Lebanese returning from the diaspora), the rate of growth of GDP has implications for the speed with which real per capita incomes return to their prewar level of $1974 . .^{5}$ At the time the

\footnotetext{
${ }^{5}$ The rate of population growth was 2.16 percent in 1992 and 2.20 percent in 1993. The assumed growth rate could well be an underestimate in the short term, given that many of the returning Lebanese are likely to be in their peak childbearing years, and because the war induced the postponement of marriages and childbearing for those who remained in Lebanon during the hostilities.
}

postwar reconstruction program was launched, real growth was projected to be 8 percent a year for 1993-96, yielding 6 percent a year real per capita growth rates, given the earlier assumption regarding population growth. Assuming a constant rate of real per capita income growth of 6 percent a year after 1993, Chart 2 shows Lebanon reattaining its 1974 level of per capita income sometime during the year 2006, at 8 percent a year growth sometime during the year 2003 , and at 10 percent a year growth sometime during the year 2001.

An important caveat to this analysis is how far measured GDP in 1993 falls short of potential output (using current stocks of capital and labor). To the extent that economic and political stability results in more efficient use of such resources, then there could be a rapid jump in measured output, similar to that which occurred following the 1982 shock to output. It is important to note that the rehabilitation of Lebanon's infrastructure, particularly the normalization of the generation and distribution of power supplies, should also stimulate a jump in both per capita output and the number of hours worked.

Given that the stocks of capital and labor in Lebanon in 1993 are similar to those that existed in 1987, a rapid jump in measured output could be expected in 1994 as actual output begins to approximate potential output. Assuming that per capita output in 1994 jumps to a level that is halfway between the level of output for the previous peak of 1987 and measured output for 1993 (to about LL 2,114 in constant 1974 Lebanese pounds) and then registers a constant rate of real per capita 


\section{Chart 2. Per Capita Real GDP, 1964-2010}

(In constant 1974 Lebanese pounds)

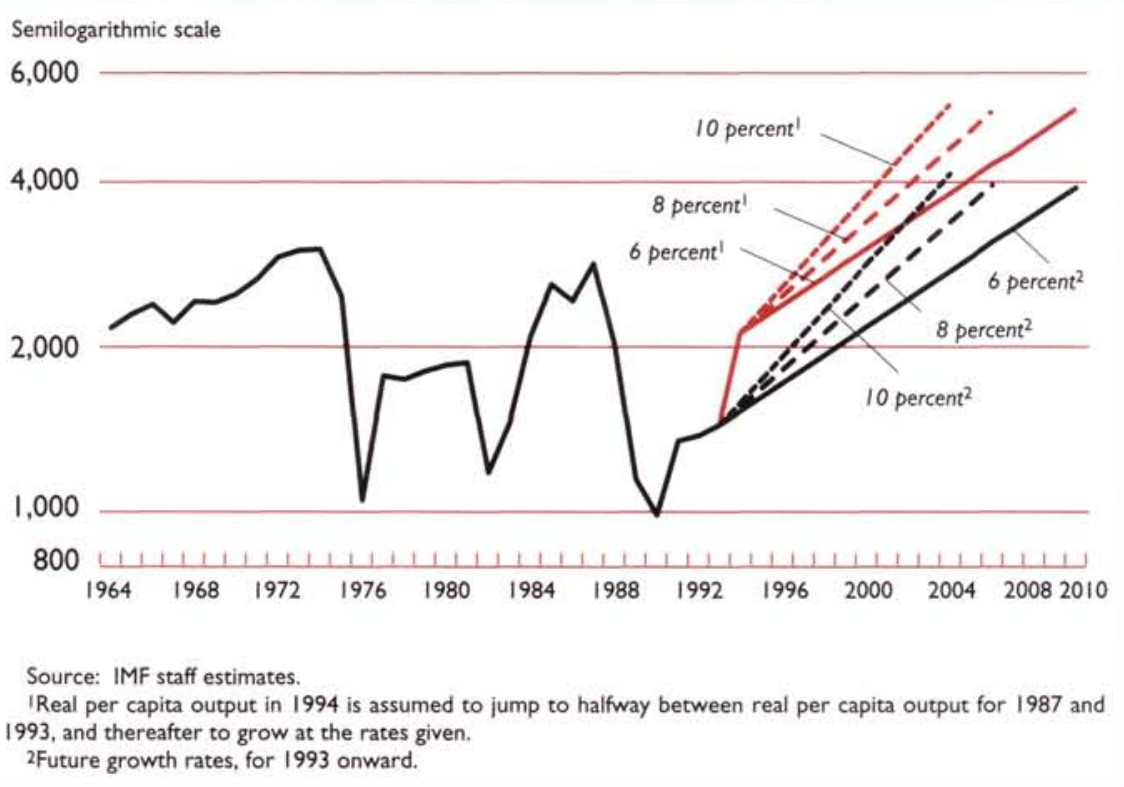

income growth of 6 percent a year after 1994, Chart 2 reveals that Lebanon would reattain its 1974 level of per capita income sometime during the year 2000. For 8 percent a year growth after 1994, the 1974 level of per capita income would be reattained sometime during the year 1999; for 10 percent a year growth after 1994, the 1974 level would be reattained sometime during the year 1998.

Previous cross-sectional analyses of the length of time necessary for the convergence of actual incomes to their steady-state level (called $\beta$-convergence in the literature) have elicited a relatively tight range of speeds at which economies travel during their transition to their respective steady-state income levels. ${ }^{6}$ Barro (1991) analyzed the pattern of growth for 98 countries, including some that are members of the Organization for Economic Cooperation and Development (OECD), between 1960 and 1985 and found that 1.11 percent of the gap between any given economy's initial level of per capita income and its steady-state level of per capita income was closed every year (that is, $\beta=0.011$ ). Similar work for the states of the United States between 1880 and 1988 by Barro and Sala-i-

${ }^{6}$ Barro and Sala-i-Martin (1994) provide a summary of the major economic growth theories. The intuition behind the convergence implication of the Solow-Swan neoclassical growth model is that, owing to diminishing returns to capital, each incremental addition to the stock of capital generates large (small) accretions in output when the stock of capital is small (large).
Martin (1992a) yields $\beta=0.0249$; for the prefectures of Japan between 1930 and 1987 by Barro and Sala-i-Martin (1992b) yields $\beta=0.034$, and between 1960 and 1988 by Shioji (1992) yields $\beta=0.033$; for the regions of European OECD countries between 1950 and 1985 by Barro and Sala-i-Martin (1992a) yields $\beta=0.0178$; for the provinces of Canada between 1961 and 1991 by Coulombe and Lee (1993) yields $\beta=0.024$; and for the states of Australia between 1861 and 1991 by Cashin (forthcoming, 1995) yields $\beta=0.0121$. Hence, the range of speeds of convergence usually described in the literature centers on $\beta=0.02$, meaning that 2 percent of the gap between an economy's initial and steady-state real per capita income level is closed each year. ${ }^{7}$

Although the above models assume closed economies, economists have long recognized that capital mobility accelerates the rate at which an economy can converge to its steady state. Indeed, an open economy with perfect capital mobility should converge at an infinite rate. However, both Cohen (1992) and Barro, Mankiw, and Sala-i-Martin (1992) have demonstrated that if some types of capital (such as human capital)

\footnotetext{
${ }^{7}$ As noted above, there is a nontrivial probability that Lebanese real output is measured with error, which typically results in biased estimates of the speed of convergence. Barro and Sala-i-Martin (1992a) test the implications of measurement error with their data on the states of the United States and find that such errors are unlikely to have a major influence on measured convergence speeds because of offsetting biases in the typical growth regression equation.
} 
cannot be financed by borrowing on world markets, then an open economy such as Lebanon's will converge to its steady state only slightly faster than the speeds calculated using the closed-economy neoclassical growth model. Partial capital mobility ensures that the credit-constrained open economy resembles a closed economy with a relatively smaller share of broad capital in GDP (denoted $\alpha$ below) - the result is that diminishing returns set in much sooner, and so the speed of convergence is faster. In effect, an open economy with partial capital mobility looks much more like a closed economy than a fully open one.

In Lebanon's case, an implication is that to the extent the civil war destroyed a sizable part of its broad (physical and human) capital stocks (postwar $\alpha$ is low), then its speed along the transition to its steady state $(\beta)$ will be relatively higher than the examples quoted above. Moreover, if following the war the Lebanese are more willing to substitute intertemporally in consumption, or have lower discount rates or higher postwar rates of depreciation, then $\beta$ will also be relatively higher. The Lebanese speed of convergence would also be raised by relatively higher rates of population growth and greater exogenous productivity growth rates. However, it is unlikely that the Lebanese would become more patient (lower discount rates) or more willing to substitute consumption intertemporally (lower elasticity of substitution in consumption) in the face of much lower levels of postwar consumption. In addition, to the extent that part of the Lebanese human capital stock returns from overseas, the speed of convergence could be faster than would otherwise be the case.

In the analysis below, it is assumed that Lebanon was at its steady-state level of real per capita income in $1974,{ }^{8}$ and then suffered the idiosyncratic shock of the civil war, leaving it with 48 percent of its 1974 steadystate per capita income at the end of 1993 (Table 2). ${ }^{9}$ If the neoclassical growth model is invoked and the nearuniversal rate of convergence of economies to their steady state of 2 percent a year is assumed, then the rate of per capita income growth in Lebanon would initially be 1.45 percent greater than the steady-state rate, 1.40 percent greater after five years, 1.33 percent greater after ten years, and still be a sizable 1.21 percent greater after twenty years (see column 2, Table 3 ). ${ }^{10}$ Given

\footnotetext{
${ }^{8}$ If not, then the time periods indicated in this analysis would be further lengthened.

$9 \mathrm{It}$ is also assumed that there is no initial jump in measured output in 1994.

10The equation for the excess of the actual growth rate of per capita income over the steady-state growth rate is given by

$$
\gamma=\gamma^{*}-\left[\left(1-e^{-\beta T}\right) / T\right] \log \left(y / y^{*}\right),
$$

where $\gamma$ is the actual growth rate of per capita income;

$\gamma^{*}$ is the steady-state growth rate of per capita income;

$\beta$ is the speed of convergence to the steady-state level;

$T$ is the number of years since 1993; and

$y / y^{*}$ is the ratio of 1993 per capita income to its steady-state value.
}

these assumptions, columns 4 and 5 of Table 3 list the number of years it would take Lebanon to partially converge to its steady-state real per capita income level for a range of speeds of convergence. ${ }^{11}$ For $\beta=0.02$, it would take Lebanon about 34 years to eliminate half the gap between its actual 1993 and steady-state incomes (that is, to catch up halfway to its steady-state level of per capita income), and about 69 years to eliminate three-fourths of the 1993 gap. ${ }^{12}$ If the speed of convergence were an extremely fast 5 percent a year, Lebanon's initial rate of per capita income growth would be 3.58 percent higher than its steady-state rate; after five years it would be 3.25 percent higher, after ten years 2.89 percent higher, and after twenty years 2.32 percent higher. Again, even with this extremely rapid speed of convergence, it would still take about 14 years to close half the gap between its actual 1993 and its steady-state per capita income, and 27 years to eliminate three-fourths of the 1993 gap. The relevant information for speeds of convergence of 3 percent and 4 percent a year are also listed in Table 3.13

This analysis indicates that economic growth and convergence of per capita incomes usually involve a period of transition lasting several generations. Given that $(\beta * 100)$ percent of the initial gap between actual and steady-state incomes is closed every year, the time taken to close, for example, the last 10 percent of the initial gap is much longer than the first 10 percent, as diminishing returns to capital ensure that the actual rate of growth in the former case is much less than in the latter. While Lebanon's postwar economy may possess some of the attributes required to shrink its period of transition to the steady state, the above calculations from a diverse group of economies indicate the sizable time lags typically involved in attaining the steadystate income.

\footnotetext{
"Speeds of convergence of real per capita incomes represent the rate at which a given economy catches up to its steady-state level, given some initial level of income. For Cobb-Douglas technology and assuming a constant gross saving rate, the speed of convergence $(\beta)$ is given by $\beta=(1-\alpha) \cdot(\xi+\eta+\delta)$, where $\alpha$ is the capital share of GDP, $\xi$ is the exogenous rate of labor-augmenting technical progress, $\eta$ is the rate of growth of population, and $\delta$ is the rate of depreciation of the capital stock. Most important, $\beta$ is a decreasing function of the capital share, $\alpha$. Therefore, $\beta$ is invariant to the level of technology used, as improvements in technology raise proportionately the steady-state and actual values of per capita income.

${ }^{12}$ The half-life of the convergence process $\left(t^{*}\right)$ is given by the following: $t^{*}=\log (1 / 2) / \log (1-\beta)$, where $\beta$ is the speed of convergence.

${ }^{13}$ To see the quantitative implications of the parameters that enter into the equation for the speed of transition, $\beta=(1-\alpha) \cdot(\xi+\eta+\delta)$ assume that $\xi=0.02$ a year, $\eta=0.025$ a year, and $\delta=0.05$ a year (which are reasonable values for a peacetime economy), but that $\alpha=$ 0.6 (which would be regarded as low for a peacetime economy but is likely to be more accurate for an economy recently at war). This set of parameters generates $\beta=0.038$ a year, so the case for expecting a relatively more rapid transition for Lebanon can indeed be made.
} 


\section{Table 3. Convergence of Actual to Steady-State Real Per Capita Incomes}

\begin{tabular}{|c|c|c|c|c|}
\hline $\begin{array}{c}\text { Speed of } \\
\text { Convergence }\end{array}$ & $\begin{array}{l}\text { Excess of Actual } \\
\text { over Steady-State } \\
\text { Growth Rate }\end{array}$ & $\begin{array}{c}\text { Number of } \\
\text { Years Since } \\
1993\end{array}$ & $\begin{array}{c}\text { Half-Life } \\
\text { of Convergence } \\
\text { Process }\end{array}$ & $\begin{array}{c}\text { Three-Quarter-Life } \\
\text { of Convergence } \\
\text { Process }\end{array}$ \\
\hline \multicolumn{2}{|c|}{ (In percent) } & (In years) & \multicolumn{2}{|c|}{ (In years) } \\
\hline 2 & 1.45 & I & 34 & 69 \\
\hline 2 & 1.40 & 5 & & \\
\hline 2 & 1.33 & 10 & & \\
\hline 2 & 1.21 & 20 & & \\
\hline 3 & 2.16 & 1 & 23 & 46 \\
\hline 3 & 2.04 & 5 & & \\
\hline 3 & 1.90 & 10 & & \\
\hline 3 & 1.66 & 20 & & \\
\hline 4 & 2.88 & 1 & 17 & 34 \\
\hline 4 & 2.66 & 5 & & \\
\hline 4 & 2.42 & 10 & & \\
\hline 4 & 2.02 & 20 & & \\
\hline 5 & 3.58 & 1 & 14 & 27 \\
\hline 5 & 3.25 & 5 & & \\
\hline 5 & 2.89 & 10 & & \\
\hline 5 & 2.32 & 20 & & \\
\hline
\end{tabular}

Source: IMF staff estimates.

\section{Does It Matter for Growth What Type of Capital Was Lost?}

Mulligan and Sala-i-Martin (1993) suggest an alternative way to conceptualize the transition along the steady state that is of particular relevance to warravaged economies such as Lebanon's. Using two-sector models of endogenous growth (with physical and human capital, for example), they analyzed the implications of deviations from the steady-state ratio of physical $(k)$ and human $(h)$ capital stocks. ${ }^{14}$ For example, if, starting from a steady-state position, a war destroys a large fraction of an economy's physical capital, leaving its stock of human capital relatively untouched, then that economy will have to reattain its steady-state proportions by higher (lower) than steadystate growth rates for physical (human) capital along the transition to its steady state.

The often complex transitional dynamics of twosector growth models can be seen in the models of Uzawa (1965) and Lucas (1988), where the transition is influenced by three key factors. ${ }^{15}$ First, when the

\footnotetext{
${ }^{14}$ Transitions arise in the neoclassical model because the actual levels of capital diverge from their steady-state values; here they can arise from intersectoral imbalances in stocks of capital.

${ }^{15}$ The Uzawa-Lucas model has a production function for education that uses only human capital as an input.
}

actual (postwar) ratio of physical capital to human capital $(k / h)$ is relatively low compared with its steadystate value $(k / h)^{*}$, then high average returns to investment in physical capital will ensure that the ratio grows rapidly (the Solow-Swan effect). Second, when physical capital is relatively low, the marginal product of labor (real wages) is also low, leading people to substitute away from work toward leisure. Third, there is a wealth- or consumption-smoothing effect that results in a high ratio of consumption to physical capital when physical capital is in relatively short supply.

For plausible parameter values (where the elasticity of substitution in consumption $(\Theta)$ is greater than the share of capital in production $(\alpha)$ ), the wealth effect dominates. ${ }^{16}$ Accordingly, an economy that lost relatively more of its physical capital stock than of its human capital stock would raise the former through increased work effort rather than through low consumption in the transition period. As we shall see, such an economy will also enjoy relatively faster growth rates during the transition to the steady state.

\footnotetext{
${ }^{16}$ It is usually regarded in the literature that $\Theta>1$, and it is known that $\alpha<1$, so therefore $\Theta>\alpha$. The higher the value of $\Theta$, the more agents in the economy dislike increasing savings in response to a relative shortage of physical capital (that is, the wealth- or consumption- smoothing effect is stronger).
} 
The behavior of other key variables along the transition from an arbitrary initial physical-to-human-capital ratio to the steady-state ratio is also of interest. Simulations using reasonable parameter values for the UzawaLucas model (and assuming that $\Theta>\alpha$ ) yield the following results: (1) real interest rates are high for low values of $(k / h)$ (for values of $(k / h)$ one-half those of $(k / h)^{*}$, initial real rates are calculated to be about 16 percent) and fall as $(k / h)$ rises; (2) the rate of growth of output exhibits a negative relationship with $(k / h) ;{ }^{17}(3)$ savings rates fall along a transition where $(k / h)$ is rising; (4) the growth rates of physical capital stocks and consumption will be positive but falling as $(k / h)$ rises; and (5) the growth rate of human capital stocks will be negative but rising as $(k / h)$ rises. Most important, the time paths for the growth rates of real GDP for an economy whose logarithm of initial postwar $(k / h)$ is half as large as $(k / h)^{*}$ reveal that the subsequent growth rate of real GDP is initially very large, at about 14 percent a year, and then falls smoothly to about 6 percent by the fifth year, reaching its steady-state value of 2 percent a year after about twenty-five years. ${ }^{18}$

Of most relevance for the growth prospects of Lebanon is the finding that the growth rate of any given

\footnotetext{
${ }^{17}$ This is an important implication of the transition for Lebanon, as it means a country that sustains significant losses in its stock of physical (human) capital on account of a war can feasibly make a relatively fast (slow) recovery.

${ }^{18}$ The key parameters in the Mulligan and Sala-i-Martin (1993) simulation had the following values: $\Theta=2$; the share of physical capital in GDP $=0.5$; the rate of time preference $=0.04 ; \gamma^{*}=0.015$ a year; and the rate of depreciation of both physical and human capital $=0.05$ a year.
}

economy along the transition path depends importantly on which of the two types of capital is in relatively short supply after an idiosyncratic shock, such as a civil war. If the relative loss of human capital is larger, then the growth rate of the economy will be slow for a long time; if the relative loss of physical capital is larger, then high marginal returns to, and short lead times of, such investment will allow the economy to recover relatively quickly. ${ }^{19}$ Although Lebanon did indeed lose labor during the net emigration period of the 1980s, it has now more than recovered its 1974 population level (Table 2 and Chart 1). While the case could be made that the education-weighted stock of human capital in Lebanon in 1993 is lower than its 1974 value, it is unlikely that the relative loss to human capital stocks is larger than that to physical capital stocks. ${ }^{20}$

In a historical context, Lebanon would then be expected to more closely resemble Germany after World War II and the South after the American Civil War (with proportionately less destruction of population than of material resources) than China after the Mongol invasions (with the reverse). Hence, in the presence of continued political and economic stability, the prospect for a relatively fast recovery of the Lebanese economy exists.

\footnotetext{
${ }^{19}$ Moreover, the nature of the physical capital loss during the war could also affect the growth rate of an economy along its transition path.

${ }^{20}$ Saidi (1984a) estimated that in 1983 Lebanon's real physical capital stock was 50 percent of its 1974 level and that during $1975-83$ the loss of physical capital was more than twice that of effective labor. There is little evidence that similar ratios would be inappropriate for the full $1974-93$ period.
} 


\section{Impact of the War on Budgetary Performance, Structural Weaknesses of the Budget, and Reform Measures}

(1) rior to the civil war, the Lebanese Government played a relatively small role in overall economic activity and pursued conservative fiscal policies. For example, during 1974-75 the budget incurred surpluses, revenues made up 15-20 percent of GDP, and government expenditure amounted to less than 15 percent of GDP. The relative importance of tax and nontax revenue was about the same, with indirect taxes dominating tax revenue. While schedular income taxation had long been in use, indirect taxes (mainly customs duties) accounted for most tax revenue. On the expenditure side, the bulk of spending comprised wages and salaries paid to government employees.

The outbreak of war resulted in a deterioration of Lebanon's revenue base and a simultaneous, relative rise in expenditures. The consequent deterioration in Lebanon's fiscal position was accommodated by financing from the Bank of Lebanon (BDL), which fueled inflation, exchange rate depreciations, and the dollarization of the economy. Furthermore, these developments dampened the relative contribution of the private sector, while increasing public expenditures widened the Government's role in the economy during and after the war. ${ }^{21}$ These issues are addressed in this and subsequent studies.

Since the ending of hostilities in 1990, Lebanon has achieved a significant level of fiscal adjustment. Although real postwar revenues have remained below the levels achieved in prewar years, they have recovered substantially relative to the war years. Real postwar expenditures have also remained at levels much higher than in prewar years but have been restrained relative to the war years. The end result was that the budget deficit declined steadily from 33 percent of GDP in 1990 to less than 9 percent in 1993.

In spite of this significant fiscal adjustment since the end of the war, Lebanon's budgetary structure continues to exhibit a number of important weaknesses. Structural weaknesses on the revenue side include a narrow revenue base, an overly complex revenue structure, limited direct taxation, a heavy reliance on nontax

\footnotetext{
${ }^{21}$ GDP data for $1976-90$ are estimates and in general understate the extent of economic activity because illegal activities, which increased significantly during the war years, were excluded.
}

revenues, and a limited capacity for tax enforcement. This pattern is similar to that which prevailed before the war. On the expenditure side, the public sector's increased role in the reconstruction process also challenges the authorities to improve budgetary management to restrain the growth of expenditure.

Because of data limitations, a comprehensive evaluation of Lebanon's fiscal performance over a long period (in particular, during the war period) cannot be undertaken. Consequently, the analysis in this section is based on information available for selected years.

\section{Overview of Fiscal Performance During and After the War}

The advent of war caused a significant deterioration in Lebanon's overall budgetary performance, and, as a percentage of GDP, revenues declined while expenditures rose considerably (Chart 3 ). Although some

\section{Chart 3. GDP and Fiscal Performance (In billions of Lebanese pounds)}

Semilogarithmic scale 100,000

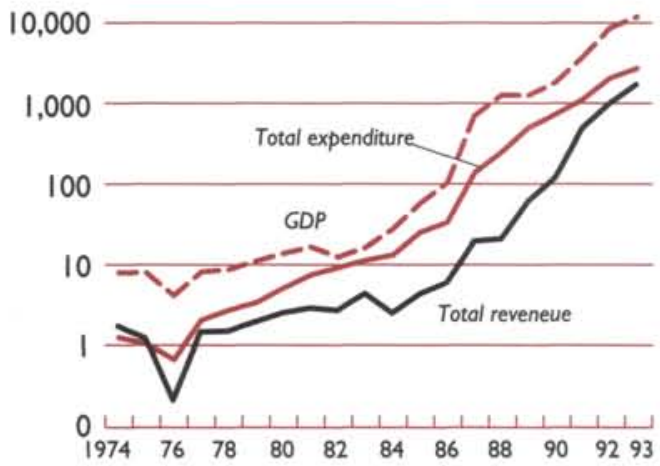

Sources: Bank of Lebanon; and IMF staff estimates. 


\begin{tabular}{|c|c|c|c|c|c|c|c|c|c|c|}
\hline & \multicolumn{2}{|c|}{ Prewar Years } & \multicolumn{5}{|c|}{ Selected War Years } & \multicolumn{3}{|c|}{ PostwarYears } \\
\hline & 1974 & 1975 & 1976 & 1980 & 1988 & 1989 & 1990 & 1991 & 1992 & 1993 \\
\hline Revenue & 1.7 & 1.2 & 0.2 & 2.5 & 21.4 & 63.8 & 126.4 & 522 & 1,060 & 1,855 \\
\hline $\operatorname{Tax}$ & 0.9 & 0.6 & 0.1 & 1.3 & 8.3 & 18.4 & 40.8 & 221 & 513 & 978 \\
\hline Direct taxes & 0.2 & 0.1 & 0.0 & 0.3 & 7.1 & 14.8 & 37.1 & 90 & 46 & 172 \\
\hline Indirect taxes & 0.7 & 0.5 & 0.1 & 1.0 & 1.2 & 3.6 & 3.7 & 132 & 467 & 806 \\
\hline Nontax' & 0.7 & 0.6 & 0.1 & 1.2 & 13.1 & 45.4 & 85.6 & 301 & 547 & 877 \\
\hline Expenditure & 1.2 & 1.0 & 0.6 & 5.1 & 263.0 & 527.8 & 778.3 & 1,196 & 2,220 & 2,957 \\
\hline Current & $\ldots$ & $\ldots$ & $\ldots$ & 4.2 & 244.5 & 495.1 & 745.2 & 1,035 & 2,074 & 2,757 \\
\hline Wages and salaries & $\ldots$ & 0.6 & 0.5 & 1.2 & 61.6 & 96.9 & 210.0 & 370 & 660 & 640 \\
\hline Interest payments & $\ldots$ & $\ldots$ & $\ldots$ & 0.2 & 80.1 & 152.2 & 213.5 & 206 & 519 & 784 \\
\hline Domestic & $\ldots$ & $\ldots$ & $\ldots$ & 0.2 & 78.8 & 151.5 & 203.5 & 204 & 454 & 754 \\
\hline Foreign & $\ldots$ & $\ldots$ & $\ldots$ & 0.0 & 1.3 & 0.7 & 10.0 & 2 & 65 & 30 \\
\hline Fuel subsidy & & & & & & & & & & \\
\hline (Electricité du Liban) & $\cdots$ & $\cdots$ & $\ldots$ & $\ldots$ & 39.6 & 99.3 & 46.0 & 35 & 145 & 181 \\
\hline Other ${ }^{2}$ & $\ldots$ & $\cdots$ & ‥ & 2.8 & 63.2 & 146.7 & 275.7 & 425 & 750 & 1,152 \\
\hline Development & $\cdots$ & $\cdots$ & $\cdots$ & 0.9 & 18.5 & 32.7 & 33.1 & 161 & 146 & 200 \\
\hline Surplus(+)/deficit(-) & 0.4 & 0.1 & -0.5 & -2.6 & -241.6 & -464.0 & -651.9 & -674 & $-1,160$ & $-1,102$ \\
\hline Financing (net) & -0.4 & -0.1 & 0.5 & 2.6 & 241.6 & 464.1 & 651.9 & 650 & 979 & 1,131 \\
\hline Domestic & -0.4 & -0.1 & 0.5 & 2.1 & 243.7 & 466.1 & 651.9 & 650 & 1,087 & 941 \\
\hline Bank & -0.4 & -0.1 & 0.5 & 1.7 & 170.2 & 399.6 & 575.7 & 183 & 1,055 & 751 \\
\hline BDL & $\ldots$ & $\ldots$ & $\ldots$ & 0.7 & -101.1 & 120.4 & 445.6 & -424 & -668 & -119 \\
\hline Other ${ }^{3}$ & $\ldots$ & $\ldots$ & $\ldots$ & 1.0 & 271.3 & 279.2 & 130.1 & 607 & 1,722 & 870 \\
\hline Nonbank & - & - & - & 0.4 & 73.5 & 66.5 & 76.2 & 467 & 32 & 190 \\
\hline Foreign & - & - & - & 0.6 & -2.1 & -2.0 & - & - & -108 & 190 \\
\hline Discrepancy ${ }^{4}$ & - & 一 & - & - & - & - & - & -24 & -181 & 29 \\
\hline \multicolumn{11}{|l|}{ Memorandum item: } \\
\hline GDP & 8 & 8 & 4 & 14 & 1,356 & 1,350 & 1,973 & 4,132 & 9,499 & 13,122 \\
\hline
\end{tabular}

Sources: Lebanese authorities; and IMF staff estimates.

Includes foreign grants in some years and adjustments with respect to monetary accounts.

2 Includes advances and transfers and adjustments with respect to monetary accounts.

${ }^{3}$ Commercial banks and Société Financière du Liban.

${ }^{4} \mathrm{Discrepancy}$ between deficit and financing.

relatively minor revenue measures were effected during the war, revenue yield was depressed, mainly as a result of the breakdown of government authority over revenue sources. Furthermore, revenue collection was adversely affected by inflation, which diminished real revenues from specific taxes, led people to delay tax payments, and induced a shift from taxed to nontaxed activities. As a result, revenues dropped substantially from 20 percent of GDP in 1974 to 5-6 percent of GDP in 1989-90 (Tables 4 and 5). In particular, customs duty receipts declined during 1988-90 owing to the loss of control over legal ports of entry and a consequent surge in illegal imports. However, toward the end of the war years, direct tax collections improved as economic activity began to recover, and the authorities instituted payment of the business profit tax on the basis of self-estimation. Nontax revenue also improved during 1989-90, as a result of the rise in real estate prices and the 6 percent ad valorem registration fee applied to real estate transactions. In addition, nontax revenue was boosted by the increase in profits of the BDL, reflecting increased treasury bill holdings by the $\mathrm{BDL}$ and profits from foreign exchange operations.

Revenue losses during the war years were not matched by a corresponding restraint in expenditure because of the Government's efforts to maintain a minimum level of public services and operations. Total expenditure rose from 15 percent of GDP in 1974 to 39 percent of GDP during 1989-90. In particular, domestic interest payments eventually absorbed a much greater share of total expenditure as the Government increasingly resorted to debt financing of budget deficits. In the event, total domestic debt increased from LL 31 billion in 1984 to LL 982 billion in 1989. 
Table 5. Summary of Public Sector Operations (In percent of GDP)

\begin{tabular}{|c|c|c|c|c|c|c|c|c|c|c|}
\hline & \multicolumn{2}{|c|}{ Prewar Years } & \multicolumn{5}{|c|}{ Selected War Years } & \multicolumn{3}{|c|}{ Postwar Years } \\
\hline & 1974 & 1975 & 1976 & 1980 & 1988 & 1989 & 1990 & 1991 & 1992 & 1993 \\
\hline Revenue & 20 & 15 & 4 & 18 & 2 & 5 & 6 & 13 & II & 14 \\
\hline Tax & II & 8 & 2 & 9 & 1 & 1 & 2 & 5 & 5 & 7 \\
\hline Direct taxes & 3 & 1 & - & 2 & 1 & 1 & 2 & 2 & - & 1 \\
\hline Indirect taxes & 9 & 6 & 2 & 7 & - & - & - & 3 & 5 & 6 \\
\hline Nontax & 9 & 8 & 2 & 8 & 1 & 3 & 4 & 7 & 6 & 7 \\
\hline Expenditure & 15 & 14 & 16 & 37 & 19 & 39 & 39 & 29 & 23 & 23 \\
\hline Current & $\ldots$ & $\ldots$ & ... & 30 & 18 & 37 & 38 & 25 & 22 & 21 \\
\hline Wages and salaries & $\ldots$ & 8 & 13 & 9 & 5 & 7 & II & 9 & 7 & 5 \\
\hline Interest payments & $\ldots$ & $\ldots$ & ... & 2 & 6 & II & II & 5 & 5 & 6 \\
\hline Domestic & $\ldots$ & $\ldots$ & $\ldots$ & 1 & 6 & II & 10 & 5 & 5 & 6 \\
\hline Foreign & $\ldots$ & $\ldots$ & $\ldots$ & - & - & - & 1 & 一 & 1 & - \\
\hline \multicolumn{11}{|l|}{ Fuel subsidy } \\
\hline (Electricité du Liban) & $\ldots$ & $\ldots$ & $\ldots$ & $\ldots$ & 3 & 7 & 2 & 1 & 2 & 1 \\
\hline Other & $\ldots$ & $\ldots$ & $\ldots$ & 20 & 5 & II & 14 & 10 & 8 & 9 \\
\hline Development & ... & ... & ... & 6 & 1 & 2 & 2 & 4 & 2 & 2 \\
\hline Surplus(+)/deflcit(-) & 5 & 2 & -12 & -19 & -18 & -34 & -33 & -16 & -12 & -8 \\
\hline
\end{tabular}

Sources: Lebanese authorities; and IMF staff estimates.

Similarly, fuel subsidies rose to a peak of 19 percent of total expenditure in $1989 .{ }^{22}$ Although intermittent adjustments in wages and salaries were effected, the Government's wage bill declined from about 13 percent of GDP in 1976 to 7 percent of GDP in 1989. Nevertheless, reflecting the full-year effect of the sharp wage increase granted in the previous year, the public sector wage bill rose to 11 percent of GDP in 1990 , and its share in total expenditure rose to 27 percent. Finally, budgetary capital expenditure declined from 6 percent of GDP in 1980 to 2 percent of GDP in 1990 and contributed to the deterioration in Lebanon's stock of public capita.

At the end of the civil war, Lebanon's budget was characterized as follows: (1) low revenue yield, mainly owing to a lack of sufficient government control over revenue sources; (2) continued dependence on indirect taxes, as had been the case prior to the war; (3) increased importance of direct tax revenue relative to indirect taxes; (4) increased burden of domestic interest payments; and (5) a low level of capital expenditure. As a result of these developments, the budget surpluses incurred prior to the war were transformed into increasing deficits during the war and postwar years. The overall deficit rose from 12 percent of GDP (76 percent

\footnotetext{
${ }^{22}$ Until 1988 , all petroleum prices were controlled by the Government; in that year, the authorities eliminated the subsidy on gasoline by privatizing the importation of gasoline and limited fuel subsidies largely to electricity generation.
}

of total expenditure) in 1976 to 33 percent of GDP (84 percent of total expenditure) in 1990 . Although the authorities increasingly resorted to domestic debt financing, they financed budget deficits largely through money creation, with some treasury bill issuance, and the share of foreign financing was insignificant. This process of money creation led to high inflation, and the government sector began to absorb an increasingly large share of domestic resources.

Significant fiscal adjustment began in 1991, when revenues increased fourfold to 13 percent of GDP as a result of the gradual reassertion of government authority over revenue sources. Widespread improvement in revenue collection occurred, particularly with respect to customs duties and nontax revenue. At the same time, restraint in current expenditure (including a hiring freeze) resulted in a significant decline in total expenditure to 29 percent of GDP, down from 39 percent in the previous year. Interest payments on domestic debt declined somewhat in real terms, owing to larger recourse to monetary financing. The fuel subsidy was limited to less than 1 percent of GDP, and other current expenditure declined by more than 3 percentage points to 10 percent of GDP. In contrast, capital expenditure increased fivefold to 4 percent of GDP, largely to restore basic public services and rehabilitate public infrastructure. These developments resulted in a substantial reduction in the overall deficit from 33 percent of GDP in 1990 to 16 percent of GDP in 1991 (56 percent of total expenditure). 
Table 6. Summary of Public Sector Operations (In percent of total)

\begin{tabular}{|c|c|c|c|c|c|c|c|c|c|c|}
\hline & \multicolumn{2}{|c|}{ Prewar Years } & \multicolumn{5}{|c|}{ Selected War Years } & \multicolumn{3}{|c|}{ Postwar Years } \\
\hline & 1974 & 1975 & 1976 & 1980 & 1988 & 1989 & 1990 & 1991 & 1992 & 1993 \\
\hline Revenue & 100 & 100 & 100 & 100 & 100 & 100 & 100 & 100 & 100 & 100 \\
\hline Tax & 56 & 49 & 55 & 53 & 39 & 29 & 32 & 42 & 48 & 53 \\
\hline Direct taxes & 13 & 7 & 5 & 14 & 33 & 23 & 29 & 17 & 4 & 9 \\
\hline Indirect taxes & 44 & 42 & 51 & 39 & 6 & 6 & 3 & 25 & 44 & 43 \\
\hline Nontax & 44 & 51 & 45 & 47 & 61 & 71 & 68 & 58 & 52 & 47 \\
\hline Expenditure & 100 & 100 & 100 & 100 & 100 & 100 & 100 & 100 & 100 & 100 \\
\hline Current & $\ldots$ & $\ldots$ & $\ldots$ & 83 & 93 & 94 & 96 & 87 & 93 & 93 \\
\hline Wages and salaries & $\ldots$ & 56 & 80 & 23 & 23 & 18 & 27 & 31 & 30 & 22 \\
\hline Interest payments & $\ldots$ & $\ldots$ & $\ldots$ & 4 & 30 & 29 & 27 & 17 & 23 & 27 \\
\hline Domestic & $\ldots$ & $\ldots$ & $\ldots$ & 4 & 30 & 29 & 26 & 17 & 20 & 25 \\
\hline Foreign & $\ldots$ & $\cdots$ & $\ldots$ & - & - & - & 1 & - & 3 & 1 \\
\hline \multicolumn{11}{|l|}{ Fuel subsidy } \\
\hline (Electricité du Liban) & $\ldots$ & $\ldots$ & $\ldots$ & $\ldots$ & 15 & 19 & 6 & 3 & 7 & 6 \\
\hline Other & $\ldots$ & $\ldots$ & $\ldots$ & 55 & 24 & 28 & 35 & 35 & 34 & 39 \\
\hline Development & $\ldots$ & $\ldots$ & $\cdots$ & 17 & 7 & 6 & 4 & 13 & 7 & 7 \\
\hline Financing & 100 & 100 & 100 & 100 & 100 & 100 & 100 & 100 & 100 & 100 \\
\hline Domestic & 100 & 100 & 100 & 79 & 100 & 100 & 100 & 100 & 111 & 83 \\
\hline Bank! & 100 & 100 & 100 & 63 & 70 & 86 & 88 & 31 & 108 & 66 \\
\hline Nonbank & - & - & - & 16 & 30 & 14 & 12 & 69 & 3 & 17 \\
\hline Foreign & - & - & - & 21 & - & - & - & - & -11 & 17 \\
\hline \multicolumn{11}{|l|}{$\begin{array}{l}\text { Memorandum item: } \\
\text { Surplus(+)/deficit(-) } \\
\text { in percent of total }\end{array}$} \\
\hline expenditure & 36 & 13 & -76 & -51 & -92 & -88 & -84 & -56 & -52 & -37 \\
\hline
\end{tabular}

Sources: Lebanese authorities; and IMF staff estimates.

Includes discrepancy between net deficit and financing.

Fiscal adjustment continued in 1992 as revenues doubled, mainly as a result of a substantial increase in both customs duty collections and nontax revenue. The share of tax revenue in total revenue increased to 48 percent and the share of indirect taxes rose to 44 percent, similar to the levels achieved in 1975. Although revenues declined somewhat to 11 percent of GDP, continued restraint in current expenditure caused total expenditure to decline to 23 percent of GDP. Consequently, the budget deficit was further lowered to 12 percent of GDP (52 percent of total expenditure) and was financed largely through debt issuance (Table 6). Increased recourse to treasury bill financing more than doubled domestic interest payments, whose share in total expenditure rose to 20 percent. In the event, the outstanding stock of treasury bills rose from LL 2,333 billion in 1991 to LL 4,754 billion in 1992. However, because of the rapid nominal growth in GDP (130 percent), ${ }^{23}$ the ratio of the nominal stock of treasury bills to GDP declined by 6 percentage points to 50 percent in 1992. While the shares of both wages and salaries

\footnotetext{
${ }^{23}$ During 1992 , the annual average rate of inflation was 120 percent.
}

and other expenditure remained at levels comparable to the previous year, the share of fuel subsidies in expenditure rose significantly, reflecting increased production and continued difficulties with tariff collection and illegal tapping. Development expenditure remained at low levels, declining relative to 1991 .

Revenues recovered further in 1993, increasing by 75 percent in absolute terms and by 3 percentage points, to 14 percent, in terms of GDP. As in 1991-92, this impressive recovery was mainly due to continued reassertion of civil authority and to improvements in tax enforcement and collection. Some significant revenue measures were also effected in 1993.

First, income taxes were revised in July 1993, to be effective as of 1994, with both the tax rates and the number of tax brackets lowered for personal and company income. ${ }^{24}$ The number of brackets for personal

\footnotetext{
${ }^{24}$ Direct taxes include taxes on income, rental income tax, and the inheritance tax. Taxes on income comprise the personal income tax and the company income tax. The bulk of revenue from taxes on income consists of company income tax (estimated by the authorities to be about 90 percent of such revenue), and personal income taxes are collected largely from employees through payroll deductions.
} 
income tax purposes was lowered from 13 to 5 , with marginal tax rates ranging from 2 percent to 10 percent, compared with 2 percent to 32 percent previously. Company income tax brackets were lowered from 12 to 4 with rates ranging from 3 percent to 10 percent (plus 5 percent on dividends if they are distributed), compared with 6 percent to 50 percent previously.

Second, a customs tariff reform law was drafted, reducing the number and the level of duty rates and imposing a minimum duty on all but a few imports. Under the new customs law, the number of rates is to be lowered from 30 to 8 , and a minimum tariff of 2 percent is to be adopted for all imports, excluding gold, silver, and currency. Accordingly, the average effective rate is to be reduced by about one-half the previous rate, including surcharges.

Third, a shift to the market exchange rate for customs valuation purposes was envisaged but has not yet been implemented. However, the exchange rate used for customs duty purposes was raised in March 1992 from LL 200 to LL 800 per US\$1. Upon implementation of the new law, the authorities will increase the exchange rate used for the valuation of imports for duty purposes from LL 800 per US $\$ 1$ to the market level. As the market exchange rate is about equal to twice the official customs exchange rate, the new customs law is projected to be revenue-neutral. However, its impact on effective tariff rates may not be neutral.

Fourth, improvements were effected in the collection of property taxes and related fees, through updating of property value assessments and increases in such fees. Finally, tariffs on electricity, telephone, and water use were doubled.

As for expenditure, total expenditure in real terms in 1993 was maintained at about the same level as in 1992 , equivalent to 23 percent of GDP. This favorable outcome was mainly the result of two factors. First, the 1993 budget was approved with a long delay and, until that time, expenditure in 1993 was implemented according to the 1992 budget appropriations, which were significantly lower than 1993 budget appropriations. As a result, significant expenditure savings were realized. Second, no wage and salary increases were granted in 1993, and the 1993 public wage bill declined further because of induced or voluntary resignations in connection with the civil service reform. While the fuel subsidy and other expenditures were maintained in real terms at about the same levels as in 1992, expenditure on domestic interest payments rose to 25 percent of total expenditure (6 percent of GDP), reflecting greater reliance on domestic financing through the issuance of government debt. However, capital expenditure remained at low levels, with no increase in real terms from 1992, because of delays in the implementation of the reconstruction program. The foregoing developments resulted in a further decline in the overall deficit to 8 percent of GDP ( 37 percent of total expenditure). The deficit was largely financed through domestic debt issuance, with foreign financing amounting to about 1 percent of GDP; in the event, the outstanding stock of treasury bills rose by 27 percent to LL 6,028 billion.

The increase in 1992-93 in the domestic debt stock to more than 45 percent of GDP has significant implications for the long-term sustainability of budget deficits at or beyond the level observed in 1993. Although the fiscal sustainability issue is outside the scope of the present study, it highlights the importance of addressing the structural weaknesses of the budget in order to ensure long-term fiscal stability and to maintain recourse to government borrowing at sustainable levels.

\section{Structural Weaknesses of the Budget}

The impressive improvement in Lebanon's fiscal stance through 1993 is attributable to the recovery of revenues and considerable expenditure restraint. Although total expenditure was effectively lowered in real terms as of the beginning of the postwar years, it remains significantly above the levels that prevailed prior to the war, resulting in a relatively higher overall deficit. Thus, the government sector has become larger than it had been before the war, absorbing a greater share of domestic resources.

The revenue composition that emerged at the end of 1993 is comparable to that of the prewar years, with indirect taxes and nontax revenue accounting for large shares of total revenue. However, total revenue mobilization in real terms still remains below the level that prevailed before the war. Although the improvement in revenue performance can be expected to continue in the coming years of reconstruction and recovery, a number of structural weaknesses remain to be addressed through substantial reform so as to improve domestic resource mobilization.

Table 7 shows the structure of Lebanon's government finances relative to those of selected Middle Eastern countries-Egypt, Iran, Jordan, Morocco, Syria, and Tunisia. Except for Jordan in 1991, Lebanon has the largest overall budget deficit but made great strides during 1991-93 in closing its fiscal deficit. Furthermore, Lebanon has the lowest total revenue-to-GDP ratio of the seven countries and, apart from Iran, the lowest total expenditure-to-GDP ratio. Despite the increase in the size of government during the war, the public sector still plays a relatively small role in the Lebanese economy.

As for the composition of revenues, Lebanon has the lowest contribution from direct taxes and (apart from Iran, an oil exporter) the highest contribution from nontax revenues, both of which point to an inelastic tax system. In addition, Lebanon, along with Jordan, has 
Table 7. Fiscal Indicators for Selected Middle Eastern Countries

\begin{tabular}{|c|c|c|c|c|c|c|c|c|c|c|c|c|}
\hline & $\begin{array}{l}\text { Overall } \\
\text { Balance }\end{array}$ & $\begin{array}{l}\text { Current } \\
\text { Balance }\end{array}$ & $\begin{array}{l}\text { Total } \\
\text { Revenuel }\end{array}$ & $\begin{array}{l}\text { Total } \\
\text { Expendi- } \\
\text { ture }\end{array}$ & $\begin{array}{l}\text { Direct } \\
\text { Taxes }\end{array}$ & $\begin{array}{l}\text { Indirect } \\
\text { Taxes }\end{array}$ & $\begin{array}{l}\text { Nontax } \\
\text { Revenue }\end{array}$ & \multirow{2}{*}{$\begin{array}{c}\text { Import } \\
\text { Duties } \\
\text { (In percent } \\
\text { of imports) }\end{array}$} & \multirow{2}{*}{$\begin{array}{c}\begin{array}{c}\text { Current } \\
\text { Expendi- } \\
\text { ture }\end{array} \\
\text { In pe }\end{array}$} & \multirow{2}{*}{$\begin{array}{c}\text { Wage } \\
\text { Bill }\end{array}$} & \multirow{2}{*}{$\begin{array}{c}\text { Interest } \\
\text { Payments }\end{array}$} & \multirow{2}{*}{$\begin{array}{c}\text { Capital } \\
\text { Expendi- } \\
\text { ture }\end{array}$} \\
\hline & \multicolumn{4}{|c|}{ (In percent of GDP) } & \multicolumn{3}{|c|}{ (In percent of total revenue) } & & & & & \\
\hline \multicolumn{13}{|l|}{ Lebanon } \\
\hline 1991 & -16.3 & -12.4 & 12.6 & 28.9 & 17.2 & 25.3 & 57.7 & 2.8 & 86.5 & 30.9 & 17.2 & 13.5 \\
\hline 1992 & -12.2 & -10.7 & 11.1 & 23.4 & 4.3 & 44.1 & 51.6 & 5.0 & 93.4 & 29.7 & 23.4 & 6.6 \\
\hline 1993 & -8.4 & -6.9 & 14.1 & 22.5 & 9.3 & 43.4 & 47.2 & 9.0 & 93.2 & 21.6 & 26.5 & 6.8 \\
\hline \multicolumn{13}{|l|}{ Egypt 2,3} \\
\hline $1991 / 92$ & -5.0 & 4.1 & 34.8 & 39.8 & 24.3 & 34.7 & 41.1 & 13.3 & 76.9 & 17.1 & 20.2 & 23.1 \\
\hline $1992 / 93$ & -4.7 & 3.9 & 35.0 & 39.7 & 23.9 & 34.8 & 41.3 & 14.4 & 79.0 & 18.8 & 25.6 & 21.0 \\
\hline $1993 / 944$ & -2.8 & 3.5 & 35.1 & 37.9 & 22.9 & 37.6 & 39.5 & 14.7 & 82.4 & 19.8 & 29.3 & 17.6 \\
\hline \multicolumn{13}{|l|}{ Iran } \\
\hline 1991 & -2.0 & 4.8 & I8.1 & 20.0 & 14.0 & 11.7 & 74.3 & $\ldots$ & 66.5 & $\ldots$ & $\ldots$ & 33.5 \\
\hline 1992 & -2.4 & 4.9 & 17.5 & 19.8 & 16.7 & 16.4 & 66.9 & $\ldots$ & 64.1 & $\ldots$ & $\ldots$ & 35.9 \\
\hline $1993^{5}$ & -1.9 & 6.0 & 18.5 & 20.5 & 17.1 & 15.3 & 67.6 & $\ldots$ & 67.3 & $\ldots$ & $\cdots$ & 32.7 \\
\hline \multicolumn{13}{|l|}{ Jordan } \\
\hline 1991 & -17.8 & -8.0 & 29.0 & $46.8^{6}$ & 11.5 & 40.7 & 47.8 & 6.6 & $86.0^{7}$ & 15.67 .8 & $25.2^{7}$ & $14.0^{7}$ \\
\hline 1992 & -3.7 & 2.1 & 36.1 & 39.96 & 9.4 & 45.9 & 44.7 & 8.6 & $84.4^{7}$ & 16.37 .8 & $24.4^{7}$ & 15.67 \\
\hline $1993^{5}$ & -6.4 & 0.1 & 32.4 & $38.8^{6}$ & 10.2 & 45.2 & 44.6 & 8.9 & $82.0^{7}$ & 17.87 .8 & 17.77 & $18.0^{7}$ \\
\hline \multicolumn{13}{|l|}{ Morocco } \\
\hline 1991 & -3.1 & 3.1 & 23.0 & 26.1 & 24.2 & 32.7 & 22.5 & 19.0 & 76.2 & 39.5 & 21.1 & 23.8 \\
\hline 1992 & -2.2 & 4.9 & 26.3 & 28.5 & 26.6 & 34.2 & 19.9 & 19.5 & 75.1 & 37.3 & 19.6 & 24.9 \\
\hline 1993 & -2.8 & 4.9 & 26.4 & 29.2 & 23.0 & 33.3 & 25.0 & 20.4 & 73.7 & 36.1 & 19.9 & 26.9 \\
\hline \multicolumn{13}{|l|}{ Syria } \\
\hline 1991 & -1.4 & 6.2 & 23.8 & 25.1 & 37.1 & 43.6 & 19.3 & 14.7 & 70.0 & 52.6 & $1.2^{9}$ & 30.0 \\
\hline 1992 & -4.9 & 4.9 & 19.8 & 24.7 & 27.4 & 49.2 & 23.3 & 10.0 & 60.4 & 44.4 & $1.4^{9}$ & 39.6 \\
\hline 1993 & -9.2 & 4.5 & 17.9 & 27.1 & 22.9 & 52.7 & 24.5 & $\ldots$ & 49.2 & 34.6 & 1.09 & 50.8 \\
\hline \multicolumn{13}{|l|}{ Tunisia } \\
\hline 1991 & -5.6 & 2.6 & 28.6 & 34.2 & 29.5 & 52.8 & 17.7 & 19.5 & 76.0 & 27.7 & 10.0 & 24.0 \\
\hline 1992 & -3.0 & 3.9 & 28.8 & 31.8 & 29.2 & 52.5 & 18.3 & 19.3 & 78.5 & 29.3 & 9.8 & 21.5 \\
\hline 1993 & -2.6 & 4.7 & 30.1 & 32.7 & 27.6 & 53.2 & 19.2 & 19.6 & 77.9 & 29.6 & 10.0 & 22.1 \\
\hline \multicolumn{13}{|c|}{$\begin{array}{l}\text { Sources: International Monetary Fund, International Finoncial Statistics; and IMF staff estimates. } \\
\text { 'Excludes grants. }\end{array}$} \\
\hline \multicolumn{13}{|c|}{$\begin{array}{l}\text { 'Excludes grants. } \\
\text { IIncludes central and local governments, food supply authority, and investment expenditure }\end{array}$} \\
\hline \multicolumn{13}{|c|}{${ }^{3}$ Fiscal year July/]une. } \\
\hline \multicolumn{13}{|c|}{ AEstimates. } \\
\hline \multicolumn{13}{|c|}{ SPreliminary actual. } \\
\hline \multicolumn{13}{|c|}{ ¿On a commitment basis. } \\
\hline \multicolumn{13}{|c|}{ 'Excludes net lending and extrabudgetary expenditure. } \\
\hline \multicolumn{13}{|c|}{${ }^{8}$ Excludes military salaries and pensions. } \\
\hline 9Domestic & debt servi & icing, includi & ing amortiz: & tion. & & & & & & & & \\
\hline
\end{tabular}

the lowest revenue from taxation of imports as a share of imports, although planned reforms to strengthen customs administration should increase such receipts. Of the seven countries, Lebanon's share of current expenditures is the highest, and its share of capital expenditures is the lowest in total spending. Such an outcome would not be expected for a country in the early stages of recovery from a civil war that destroyed a sizable part of its stock of capital. Finally,
Lebanon (with Egypt) devotes a large and growing share of its expenditure to servicing its debt commitments, which reduces the authorities' flexibility to conduct fiscal policy and respond to unforeseen shocks to the economy.

These observations point to the following main structural weaknesses on the revenue side: (1) there is a heavy reliance on indirect taxes and relatively small income tax collections, while taxable income is not 
applied on global earnings; ${ }^{25}$ (2) although the bulk of indirect taxes consists of customs duties, the average effective taxation of imports remains low; (3) existing excise taxes are largely outmoded and very limited in scope and yield; ${ }^{26}$ there is no comprehensive tax on consumption, such as a general sales tax; (4) there is an overemphasis on nontax revenue, such as various fees, charges, fines, and miscellaneous property and enterprise income; and (5) the effectiveness of tax administration and collection is still limited.

As regards expenditures, the Government is expected in the coming years to continue with its large reconstruction program, resulting in a major increase in capital outlays. Additionally, the budgetary wage bill is anticipated to increase as a result of the recent adjustments in wages and salaries, ${ }^{27}$ which declined in real terms during the war. Calculations for 1981-93 indicate that the level of minimum wages declined in real terms by an estimated 80 percent, mainly because of the high inflation rates in the intervening years. Further, in order to contain inflationary pressures, the authorities intend to continue financing budget deficits through debt creation, which is anticipated to increase substantially the budgetary burden of domestic interest payments. Massive reconstruction projects, to be undertaken directly by the Government and other public entities (in particular, by the Council for Development and Reconstruction (CDR)), are slated to be financed largely from foreign concessional loans and official grants. The magnitude of the financing need is likely to increase sharply the level of foreign indebtedness and foreign debt service, which was relatively low until 1993.

\section{Measures to Address the Structural Weaknesses}

The authorities are committed to undertaking fiscal reform measures with a view to addressing the structural weaknesses of revenues and strengthening expenditure management and control. These measures are seen as necessary given that the Government is launching a large investment program to rebuild infrastructure and initiate economic recovery and will help ensure high sustainable levels of growth with financial stabili-

\footnotetext{
${ }^{25}$ For example, tax on income from rental property is subject to a different schedule.

${ }^{26} \mathrm{Apart}$ from a 10 percent levy imposed on water, electricity, and telecommunications, the main excisable items are petroleum products, cement, alcoholic beverages, and tobacco and cigarettes. Excises on these items are levied at specific as opposed to ad valorem rates; specific rates greatly limit the responsiveness of revenues to price increases and encumber tax administration.

${ }^{27}$ Effective January 1, 1994, a 68.9 percent minimum wage increase was granted, which raised wages from about LL 118,000 a month (about \$70) to LL 200,000 (about \$120); higher wage levels were adjusted upward on the basis of a graduated scale.
}

ty. Toward these ends, the authorities are considering a number of fiscal measures and have sought technical assistance in this regard from the IMF and the World Bank. Expectedly, under the difficult postwar circumstances, the formulation and implementation of reform measures take time.

With regard to revenues, the authorities are initiating efforts to reform excise taxes and are considering adopting comprehensive consumption taxes with the following objectives: improve transparency, simplify tax administration, and strengthen revenues by improving their elasticity with respect to changes in income and price levels over time. They have also begun to improve tax administration by rehabilitating and computerizing tax records and assigning individual taxpayer identification numbers (TINs), as well as by establishing a tax unit to target taxpayers with large incomes. Furthermore, the authorities are considering measures to improve customs administration. ${ }^{28}$

On the expenditure side, the authorities are reforming the civil service in two phases. The first phase encompasses the immediate rehabilitation of the civil service, and the second phase aims at a medium- to longer-term restructuring of the system. The main objectives of the reform are to retrench superfluous employees, tighten and clarify hiring standards for government ministries, and improve the quality of the civil service over the medium term. Under the first phase, in December 1993, the public payroll was reduced by some 4,000 employees, comprising mainly "ghost" workers, early retirements, and induced resignations.

In the second phase, a number of reform measures have already been implemented: (1) a study of the personnel needs of government ministries and public utilities has been completed; (2) a series of decrees have been issued to cut down absenteeism and further eliminate ghost workers; (3) special legislation has been passed to reduce the number of government employees, targeting mainly corrupt and negligent workers; (4) some $3,500-5,000$ badly placed noncadre (contractual) employees have been identified, with a view to retraining and redeploying them in areas of government service where they are needed (for example, municipal governments); and (5) a rule has been adopted to disallow the filling of government ministries' cadre allocations by the authority of each individual ministry alone, requiring a joint decision by the Cabinet to fill such vacancies; this rule is intended to minimize the scope for political appointments. Further, the authorities are creating an institutional development unit to establish guidelines and priorities for administrative reform over the medium to long term, and a technical cooperation unit to direct and implement

\footnotetext{
${ }^{28}$ Under the proposed World Bank schedule, customs administration reform will be implemented gradually over 1994-97.
} 
technical assistance for administrative rehabilitation and capacity utilization.

In view of the need to contain the growth in current expenditure, the authorities acknowledge that public sector wage and employment policy requires close monitoring. Their goals are to reduce public sector employment and, in competition with the private sector, to improve the wages of qualified personnel in government service while containing the aggregate wage bill at affordable levels.

To reduce the share of domestic interest payments in total expenditure, the authorities have taken steps to lower domestic interest rates, including introducing longer-term debt instruments, increasing access to such instruments by the nonbank public, and developing secondary markets. In addition, they are trying to secure foreign financing on largely concessional terms or in the form of official grants for reconstruction outlays. To reduce the burden of the Electricité du Liban (EDL) fuel subsidy, the authorities are improving tariff collection, eliminating illegal tapping, and adjusting electricity tariffs in a timely manner. Furthermore, they are trying to attract private sector participation in public investment projects through privatization and build- operate-transfer (BOT) schemes for projects currently planned by the CDR. Both measures should help slow the growth in public indebtedness associated with the reconstruction program.

The authorities are giving priority to improving budgeting procedures and expenditure control over the medium term. They have already drawn up a bill to separate budget preparation and execution from treasury operations and initiated computerized monitoring systems. Finally, the authorities are improving the fiscal data base with a view to monitoring more closely the evolution of expenditure and revenue, and enhancing the timeliness of policy decisions. ${ }^{29}$

\footnotetext{
${ }^{29}$ Subsequent to IMF technical assistance on government finance statistics (GFS), the authorities are establishing a GFS data compilation system, to be accomplished in three phases. Under Phase I, a fiscal data base would be established that covers all central government operations that are included in the budget. Under Phase II, the operations of social security funds and the six extrabudgetary accounts, including the CDR, would be consolidated with those of the budgetary accounts to form consolidated central government. In Phase III, the operations of local government units (municipalities) would be consolidated with the rest of the government sector to form consolidated general government.
} 


\section{Currency Substitution and Dollarization}

T his section investigates currency substitution and dollarization in the Lebanese context during 1964-93, and particularly since the start of the civil war. To provide a more accurate insight into the public's asset portfolio response since the beginning of the war, the origins and extent of Lebanese currency substitution and dollarization are examined. This is followed by a look at capital flight and repatriation and their key determinants. Finally, the relative merits and demerits of pursuing a policy of de-dollarization of the Lebanese economy, as well as the requirements for achieving such a goal, are discussed.

When civil disturbances erupted in 1975, the immediate response of the public was a portfolio switch to liquid assets; the ongoing nature of the conflict and its accompanying high rates of domestic inflation then induced the abandonment of the Lebanese pound in favor of the U.S. dollar and dollar-denominated deposits. In the face of heightened political and economic risk in the 1980 s, a spatial rearrangement of Lebanese wealth portfolios occurred, involving largescale capital flight. While recent years of economic stability have prompted capital repatriation, there was little evidence of an increased desire by the Lebanese to hold pound-denominated assets between 1990 and the end of 1993 (Table 8).

Dollar currency in circulation in Lebanon serves as a store of value, a unit of account, and a medium of exchange, and the economy has, particularly since 1985 , been operating with extremely high levels of both foreign currency in circulation and foreign deposits in the domestic banking system. However, in gauging the substitutability between Lebanese pounds and U.S. dollars, data are available only for bank deposits denominated in these two currencies, and for Lebanese pound currency holdings. Dollar currency in circulation in Lebanon is unobservable; no official data exist, and individuals are unlikely to respond accurately to queries about their dollar holdings. ${ }^{30}$

Currency substitution is defined here as the use of foreign currencies as a means of exchange; dollarization is defined here as the use of U.S. dollars as the unit

\footnotetext{
${ }^{30}$ See Wilson (1992) for an analysis of the difficulties U.S. monetary authorities have in estimating the extent and direction of crossborder movements of dollars.
}

of account and the use of dollar-denominated assets as a store of value (Calvo and Vegh (1992)). Giovannini and Turtelboom (1992) have discussed the factors determining currency substitutability in the context of the unit of account, store of value, and medium of exchange functions of money. Currency substitution in the Middle East has been previously examined for Egypt and the former Yemen Arab Republic by ElErian (1988) and Elkahif and Kubursi (1991), and for Lebanon by Osseiran (1987).

\section{Origins and Extent of Dollarization}

The use of foreign currencies in any given economy varies positively with high and variable domestic inflation rates and uncertainty over domestic economic policies, both of which serve to lower the relative demand for domestic fiat money. Indeed, Melvin (1988) characterizes dollarization as a demand-side monetary reform, where economic agents substitute away from an unstable domestic monetary unit.

The extent of dollarization (defined as the ratio of foreign currency deposits $(F C D)$ to total deposits $(T D)$, $F C D / T D$ ) and the ratio of Lebanese pound currency holdings to Lebanese pound deposits (LL/LLDEP) over the period 1964-93 are documented in Chart 4. Three points stand out regarding the $L L / L L D E P$ ratio: (1) the flight to liquidity in the wake of the banking crisis of 1967-68, which raised the ratio from 25 percent in 1965 to an average of about 39 percent between 1967 and 1969 ; (2) a jump in the ratio to 49 percent in reaction to the early days of the civil war in 1975 and 1976, declining thereafter to a low of 15 percent in 1985 ; (3) further war-induced jumps in the ratio in 1987 (to 34 percent) and 1990 (to 36 percent), with a rapid decline in the ratio in 1993 to near historically low levels ( 15 percent), as the population continued to abandon the Lebanese pound in favor of the U.S. dollar as a medium of exchange.

In the face of protracted hostilities, accelerating domestic inflation, and exchange rate devaluation, the preferred response of economic agents was to make dollar-denominated deposits the chosen store of value. This move (as shown by the FCD/TD ratio) is notice- 


\section{Table 8. Currency Substitution}

\begin{tabular}{|c|c|c|c|c|c|}
\hline & $\begin{array}{c}\text { Money (MI) } \\
\text { (I) }\end{array}$ & $\begin{array}{l}\text { Demand } \\
\text { Deposits } \\
\text { (2) }\end{array}$ & $\begin{array}{l}\text { Currency in } \\
\text { Circulation } \\
\text { (3) }\end{array}$ & $\begin{array}{c}\text { Ratio LL Deposits } \\
\text { to Total } \\
\text { Deposits } \\
(4)\end{array}$ & $\begin{array}{c}\text { Annualized } \\
\text { Change in } \\
\text { LUUS\$ } \\
\text { (5) }\end{array}$ \\
\hline & \multicolumn{3}{|c|}{ (In millions of Lebanese pounds) } & \multicolumn{2}{|c|}{ (In percent) } \\
\hline 1964 & $1,390.00$ & 889.80 & 500.20 & 83.21 & -0.76 \\
\hline 1965 & $1,510.00$ & 961.60 & 548.40 & 81.75 & -0.06 \\
\hline 1966 & $1,540.70$ & 893.60 & 647.10 & 80.61 & 1.92 \\
\hline 1967 & $1,569.90$ & 782.20 & 787.70 & 80.15 & 2.36 \\
\hline 1968 & $1,749.30$ & 909.10 & 840.20 & 81.32 & -1.49 \\
\hline 1969 & $1,657.30$ & 787.00 & 870.30 & 79.33 & 3.10 \\
\hline 1970 & $1,676.50$ & 830.00 & 846.50 & 78.38 & 0.44 \\
\hline 1971 & $2,001.50$ & $1,080.00$ & 921.50 & 77.86 & -1.26 \\
\hline 1972 & $2,274.70$ & $1,239.30$ & $1,035.40$ & 79.97 & -5.48 \\
\hline 1973 & $2,618.90$ & $1,389.90$ & $1,229.00$ & 76.37 & -14.43 \\
\hline 1974 & $2,998.20$ & $1,642.20$ & $1,356.00$ & 76.99 & -10.83 \\
\hline 1975 & $3,835.90$ & $1,587.70$ & $2,248.20$ & 75.15 & -1.11 \\
\hline 1976 & $4,904.80$ & $1,803.60$ & $3,101.20$ & 78.02 & 24.74 \\
\hline 1977 & $5,061.50$ & $2,299.60$ & $2,761.90$ & 77.65 & 6.87 \\
\hline 1978 & $6,147.80$ & $2,838.00$ & $3,309.80$ & 80.63 & -3.70 \\
\hline 1979 & $6,683.80$ & $3,151.70$ & $3,532.10$ & 69.43 & 9.72 \\
\hline 1980 & $7,666.60$ & $3,668.40$ & $3,998.20$ & 63.76 & 5.96 \\
\hline 1981 & $9,005.10$ & $4,359.70$ & $4,645.40$ & 58.64 & 25.55 \\
\hline 1982 & $11,069.80$ & $5,467.80$ & $5,602.00$ & 73.29 & 9.96 \\
\hline 1983 & $12,945.00$ & $5,867.70$ & $7,077.30$ & 73.65 & -4.54 \\
\hline 1984 & $13,783.60$ & $6,089.00$ & $7,694.60$ & 68.94 & 43.79 \\
\hline 1985 & $20,154.20$ & $9,852.00$ & $10,302.20$ & 64.90 & 152.14 \\
\hline 1986 & $30,325.60$ & $15,557.40$ & $14,768.20$ & 29.04 & 133.72 \\
\hline 1987 & $68,890.00$ & $29,541.00$ & $39,349.00$ & 8.08 & 485.34 \\
\hline 1988 & $182,862.00$ & $65,810.00$ & $117,052.00$ & 20.87 & 82.21 \\
\hline 1989 & $287,186.00$ & $92,526.00$ & $194,660.00$ & 33.07 & 21.37 \\
\hline 1990 & $449,923.00$ & $115,271.00$ & $334,652.00$ & 26.68 & 39.94 \\
\hline 1991 & $689,405.00$ & $202,007.00$ & $487,398.00$ & 32.42 & 33.54 \\
\hline 1992 & $1,199,399.00$ & $393,537.00$ & $805,862.00$ & 31.86 & 84.52 \\
\hline 1993 & $1,213,887.00$ & $498,918.00$ & $714,969.00$ & 32.34 & 1.67 \\
\hline
\end{tabular}

Sources: Bank of Lebanon; International Monetary Fund, Internotional Financial Stotistics; and IMF staff estimates.

able for the period $1978-81$ and, more particularly, 1985-89 (Chart 4). While the $F C D / T D$ ratio rose to 42 percent in 1981 and peaked at 92 percent in 1987, it remained high at about 67 percent during 1991-93. The Lebanese people appear to be viewing the continued run of primary fiscal deficits and the accompanying buildup of domestic debt as leading indicators of future rounds of deficit monetization, inflation, and depreciation. Chart 5 reveals the close link between the $F C D / T D$ ratio and movements in the exchange rate, as the Lebanese moved their wealth out of pound-denominated assets into dollars and dollar-denominated domestic and foreign bank deposits. However, it should be noted that in measuring movements in the FCD/TD ratio, an upward bias could arise in the presence of a depreciation of the Lebanese pound. Conversely, a downward bias could be imparted to the extent that foreign currency deposits are moved offshore.

\section{Capital Flight and Repatriation}

Dollarization and its close cousin, capital flight, are weak and strong forms of the same phenomenon-the desire of economic agents to minimize the risk associated with holding fiat currencies as a store of value. What distinguishes capital flight from dollarization (the reorientation of economic agents' portfolios of domestic assets from local to foreign currencies) is that the former occurs in response to domestically undiversifiable risk that has the potential to alter the value of domestic assets.

During the early 1980 s, with continuing uncertainty over the stability of the domestic banking system, capital flight occurred and wealth was moved offshore into cross-border U.S. dollar deposits. As a measure of capital flight and its return to Lebanon, Charts 6, 7, and 8 present data on bank deposits held abroad during 


\section{Chart 4. Currency Substitution and Dollarization \\ (In percent)}

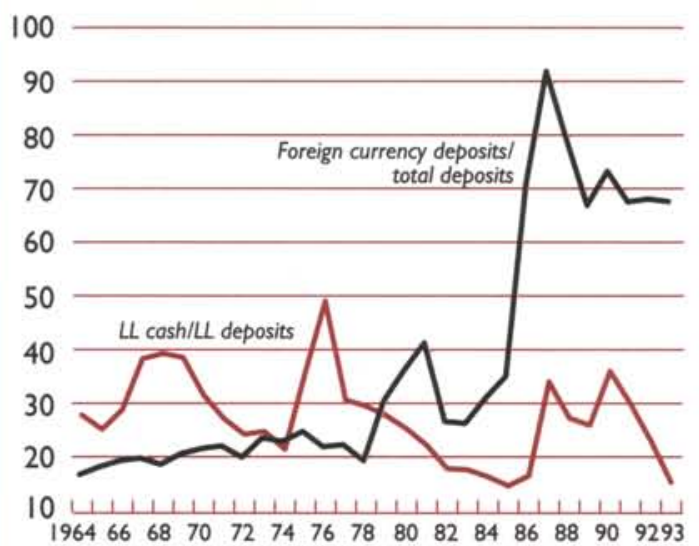

Source: International Monetary Fund, International Financial Stotistics.

\section{Chart 5. Dollarization and Exchange Rate Movements \\ (In percent)}

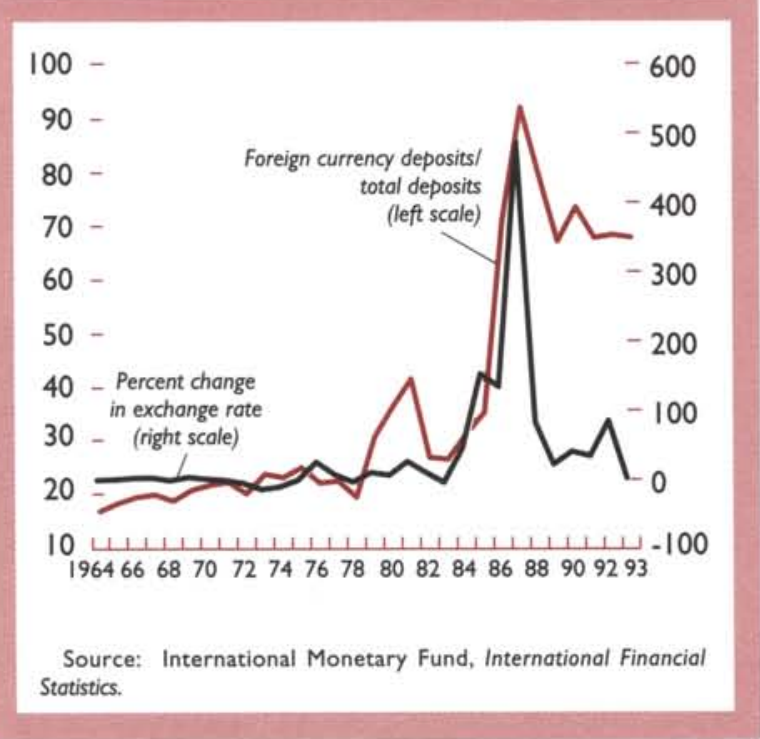

1981-93, comprising the sum of cross-border deposits by Lebanese residents (line 7xrd of International Financial Statistics) and cross-border interbank claims

\section{Chart 6. Real and Nominal Cross-Border Deposits \\ (In millions of U.S. dollars)}

Semilogarithmic scale

13,000

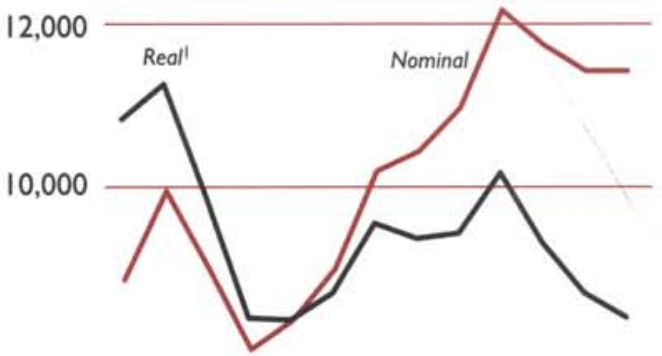

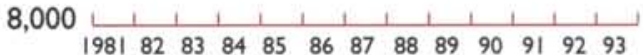

Source: International Monetary Fund, International Financial Stotistics.

IIn constant I985 U.S. dollars.

by Lebanese banks (line 8xad of International Financial Statistics). ${ }^{31}$ Chart 6 presents the value of crossborder deposits in nominal and real (constant 1985) U.S. dollar terms- the rise in such deposits after the war shocks of 1981-82 and 1986-87 is clear, although real cross-border deposits peaked in 1990 and have been declining continually since then.

While there are similarities between Lebanon and many South American countries in terms of the motivation for capital flight, Lebanese flight differed in that both Lebanese capital and labor departed during the 1980 s, whereas South Americans largely moved only their capital offshore during the same period. Similarly, the return of Lebanese capital in the 1990s has been accompanied by net immigration on a much larger scale than is typically observed in South America.

Cross-border deposits as a percentage of Lebanon's foreign exchange reserves (excluding gold) and $M 2$ are

\footnotetext{
${ }^{31}$ Capital flight could take forms other than bank deposits in the new host country, such as property assets and nondeposit financial assets, but it would be reasonable to assume that Lebanese residents would want to keep a large proportion of their foreign-based wealth relatively liquid to facilitate its repatriation to Lebanon when the economy stabilized. Note that the International Financial Statistics cross-border deposit data do not take account of transactions where deposits of Lebanese residents are held in the name of a foreign resident in a foreign bank. For the above reasons, the data on foreign currency deposits are probably a lower bound of the holdings of foreign money balances by Lebanese residents (see Agénor and Khan (1992)).
} 


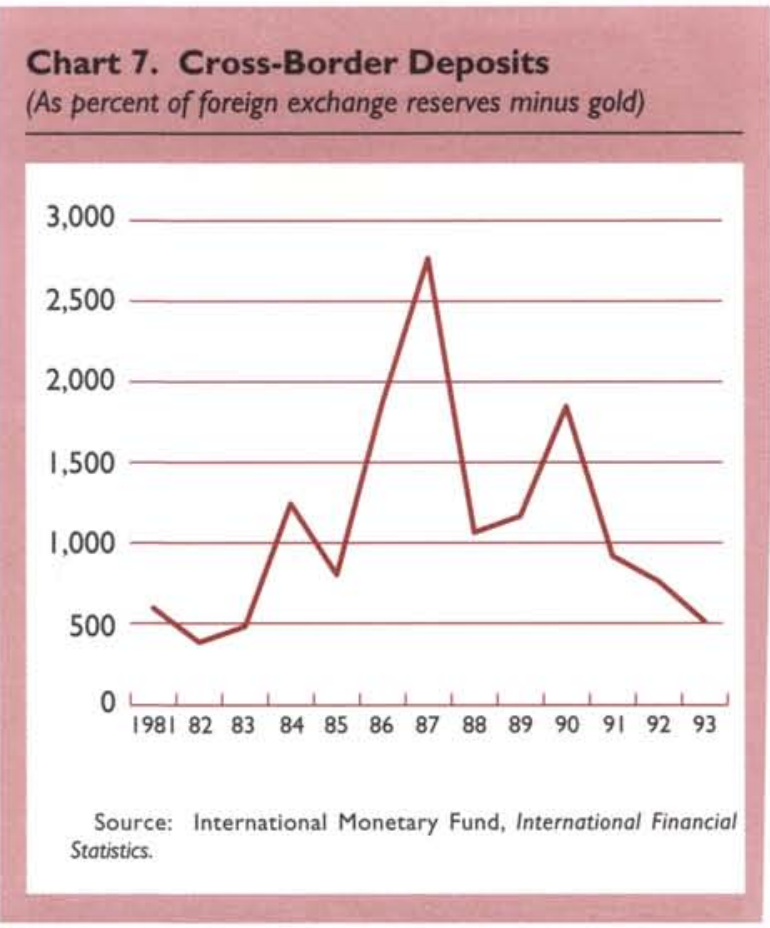

given in Charts 7 and 8 , respectively, revealing the large jumps in these ratios in 1987 and (less so) in 1990 , and declining thereafter. Indeed, at their peak in 1987 the ratio of cross-border deposits to reserves excluding gold and to $M 2$ had reached the strikingly high levels of 2,767 percent and 297 percent, respectively. At the end of 1993, the corresponding ratios were 510 percent and 97 percent. Clearly, the economic and political stability in the period since the Taïf Accord has induced the repatriation of a large portion of the wealth of Lebanese residents that was sent overseas as bank deposits between 1985 and 1990 . Although this stability resulted in a return of much of the flight capital, by the end of 1993 it had had relatively little impact on either the share of foreign currency deposits in total deposits or on the continuing use of the U.S. dollar as a means of exchange and a unit of account in Lebanon.

\section{Advantages and Disadvantages of Dollarization}

The above analysis reveals that at the end of 1993 only about 32 percent of total deposits at banks were denominated in Lebanese pounds. Given such high existing levels of dollarization and the wide circulation of the U.S. dollar as a medium of exchange, a key issue for the Lebanese authorities concerns the advantages and disadvantages of striving to achieve either full dollarization (such as Panama) or full de-dollarization.

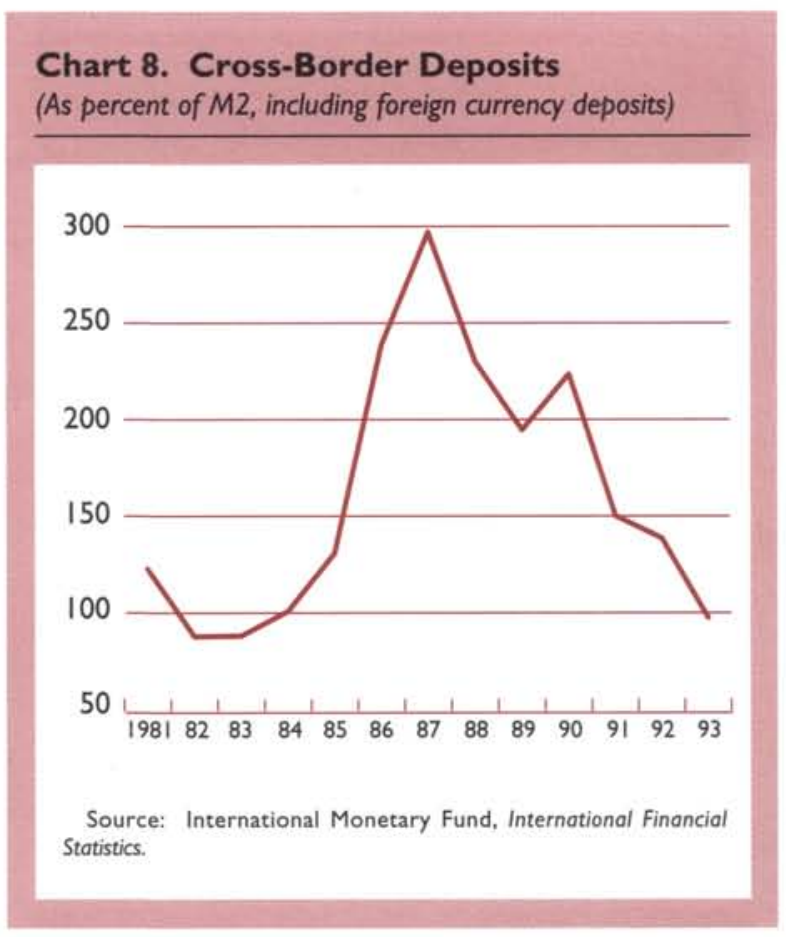

Full dollarization would preclude an independent Lebanese monetary policy but would not be much different from using the exchange rate as a nominal anchor for the economy. Full dollarization would also involve the loss of seigniorage revenues (which would then accrue to the United States), although the base for the inflation tax (holdings of pound-denominated currency) has shrunk considerably since 1975 , as noted above. Table 9 shows the expected increase in the rate of the inflation tax (defined as the ratio of the change in the monetary base to GDP) owing to the collapse of the inflation tax base (see Fischer (1982)). The average annual revenue yield from the inflation tax in Lebanon during 1965-74 was 4.12 percent of GDP; during 1975-86, 8.83 percent of GDP; during 1987-93, 7.63 percent of GDP; and 6.91 percent of GDP for the full 1965-93 period. The inflation tax yield jumped dramatically in 1976 and 1982, years that were associated with heightened war activities and an accompanying decline in output; as a result of Arab aid under the Tunis Agreement, the tax was actually negative in 1979.

The inflation tax remained high during 1986-93, owing to the large increase in currency substitution and the authorities' consequent need to raise the inflation tax rate by increasing the supply of base money. Lebanon's heavy reliance on the inflation tax has been slow to decline, largely because of the slow pace at which expenditure reductions and nonseigniorage revenue increases have occurred. This result also supports work by Khan and Ramirez-Rojas (1986) and Vegh 


\section{Table 9. Average Inflation Tax}

\begin{tabular}{|c|c|c|c|c|}
\hline \multirow[b]{2}{*}{ Year } & $\begin{array}{l}\text { Base } \\
\text { Money }\end{array}$ & $\begin{array}{l}\text { Change in } \\
\text { Base Money }\end{array}$ & $\begin{array}{l}\text { Nominal } \\
\text { GDP }\end{array}$ & \multirow{2}{*}{$\begin{array}{c}\text { Average } \\
\text { Inflation } \\
\text { Tax' } \\
\text { (In percent) }\end{array}$} \\
\hline & \multicolumn{3}{|c|}{ (In millions of Lebanese pounds) } & \\
\hline 1965 & 659 & 55 & 3,523 & 1.56 \\
\hline 1966 & 834 & 175 & 3,867 & 4.53 \\
\hline 1967 & 945 & III & 3,820 & 2.91 \\
\hline 1968 & 1,127 & 182 & 4,273 & 4.26 \\
\hline 1969 & 1,172 & 45 & 4,565 & 0.99 \\
\hline 1970 & 1,199 & 27 & 4,866 & 0.55 \\
\hline 1971 & 1,462 & 263 & 5,399 & 4.87 \\
\hline 1972 & 1,643 & 181 & 6,365 & 2.85 \\
\hline 1973 & 1,877 & 234 & 7,103 & 3.29 \\
\hline 1974 & 3,131 & 1,254 & 8,137 & 15.41 \\
\hline 1975 & 3,172 & 40 & 7,500 & 0.54 \\
\hline 1976 & 4,229 & 1,057 & 4,099 & 25.79 \\
\hline 1977 & 4,751 & 522 & 8,199 & 6.37 \\
\hline 1978 & 5,384 & 633 & 8,799 & 7.20 \\
\hline 1979 & 5,209 & -175 & 11,150 & -1.57 \\
\hline 1980 & 6,197 & 988 & 14,000 & 7.06 \\
\hline 1981 & 7,156 & 959 & 16,800 & 5.71 \\
\hline 1982 & 10,147 & 2,991 & 12,599 & 23.74 \\
\hline 1983 & 11,584 & 1,437 & 16,573 & 8.67 \\
\hline 1984 & 13,170 & 1,586 & 28,171 & 5.63 \\
\hline 1985 & 18,642 & 5,472 & 59,329 & 9.22 \\
\hline 1986 & 25,138 & 6,496 & 108,096 & 6.01 \\
\hline 1987 & 57,706 & 32,568 & 740,743 & 4.40 \\
\hline 1988 & 195,952 & 138,246 & $1,356,000$ & 10.20 \\
\hline 1989 & 332,038 & 136,086 & $1,350,000$ & 10.08 \\
\hline 1990 & 509,070 & 177,032 & $1,973,000$ & 8.97 \\
\hline 1991 & 800,051 & 290,981 & $4,132,000$ & 7.04 \\
\hline 1992 & $1,521,861$ & 721,810 & $9,499,000$ & 7.60 \\
\hline 1993 & $2,190,136$ & 668,275 & $13,122,000$ & 5.09 \\
\hline
\end{tabular}

Sources: Bank of Lebanon; International Monetary Fund, International Financial Stotistics; and IMF staff estimates.

IThe ratio of the change in base money to nominal GDP.

(1989), who showed that the greater the incidence of currency substitution, which raises the elasticity of real money demand, the higher the optimal inflation tax for a given level of government spending. Moreover, the greater the use of foreign money, the stronger the inflationary impact of the monetization of any given fiscal deficit.

It should be noted that full dollarization is unlikely to be a useful substitute for fiscal discipline because it removes the "lender of last resort" role of the central bank. This role is likely to become important if commercial banks are pressured to lend to the Government to make up for forgone seigniorage revenues. On the positive side, full dollarization would, in principle, allow Lebanon to enjoy the interest rates and inflation rates of the United States, which would make it easier to finance the reconstruction efforts required to rehabilitate the physical capital stock of the econ- omy. ${ }^{32}$ It would also lower the risk premium attached to domestic interest rates, which would in turn lower the financing costs of the existing internal debt.

What is the likely effect of dollarization on the success of a stabilization program? It can be argued that, by shrinking the inflation tax base, dollarization actually facilitates stabilization. It does this by minimizing the authorities' incentive to exercise their monopoly powers over the issuance of fiat money by monetizing fiscal deficits. ${ }^{33}$ Bufman and Leiderman (1993) find that even small increases in dollarization can have a significant impact on seigniorage revenues. This argument emanates from those who argue that competition among fiat currencies in an economy is beneficial because it minimizes the incentive for governments to engage in inflation-inducing policies.

Within the context of a flexible exchange rate system, a case has been made for currency substitution and dollarization as a beneficial outcome, as both induce price competition in the Lebanese economy between local and foreign currencies as stores of value and mediums of exchange: relatively greater use will be made of the low-inflation currency (see Girton and Roper (1981)). However, it is likely that too great a degree of currency substitution will make the use and maintenance of the exchange rate as a nominal anchor unsustainable by raising the volatility of the rates of growth of the currencies required to maintain rate parity (see Woodford (1990)).

\section{Policies to Achieve, and Consequences of, De-Dollarization}

In the few countries where de-dollarization has occurred (e.g., Bolivia, Peru, and Mexico in the 1980s), it has been involuntary. Typically, it entails confiscating dollar-denominated assets by exchanging them into the (usually inflating) domestic currency at less than the prevailing market exchange rate. In this sense, advocating a reduction in currency substitution as a policy goal is analogous to attacking the symptom of a disease rather than its cause, which, in Lebanon, is its fiscal deficits.

A government desiring to entice its citizens to voluntarily reverse the extent of foreign fiat currencies in circulation, the share of foreign currency deposits in total deposits, and the share of assets they hold abroad will need to satisfy several preconditions. First, the expected real return on assets denominated in Lebanese pounds will need to be raised or, more accu-

\footnotetext{
${ }^{32}$ There would still be a margin reflecting country- and/or regionspecific risks.

${ }^{33}$ However, there is unlikely to be a complete guarantee that a system of full dollarization will not be reversed in the future (see the case of Liberia in the 1980s).
} 
rately, the spread between Lebanese pound borrowing and lending rates reduced. ${ }^{34}$ Second, this increase in relative returns will need to be brought about by a fall in the stock of domestic money. ${ }^{35}$ Third, fiscal and monetary policies need to be consistent and credible to dissuade the private sector from engaging in currency substitution. Fourth, expectations of future exchange rate movements should induce a shift in the composition of individuals' desired portfolios of domestic and foreign assets.

In the absence of a significant further reduction of the fiscal deficit, the economic cost of de-dollarization may be large if it raises real domestic interest rates to such an extent that it dampens investment and domestic activity. This is likely to be an important consideration in a Lebanese economy that is trying to rebuild its war-damaged capital stock. Without a tight fiscal stance, a clear potential conflict exists between the simultaneous achievement of the authorities' goals of de-dollarization and rapid economic reconstruction.

\footnotetext{
${ }^{34} \mathrm{However}$, increasing returns to pound-denominated deposits will only temporarily increase the demand for the pound in the absence of a solution to Lebanon's fiscal disequilibrium.

${ }^{35}$ Such a fall is unlikely at a time of de-dollarization. However, an increase in relative returns could be achieved with a rate of growth of demand for domestic currency greater than the rate of growth of its supply.
}

The low real interest rates, which would aid reconstruction, contrast with policies required to reassert the pound as the currency of choice in Lebanon.

The absence of reserve requirements on foreign currency deposits provides an incentive for continued dollarization-lowering the reserve requirements on Lebanese pound deposits and imposing a reserve requirement on U.S. dollar deposits would achieve the twin aims of providing the authorities with an instrument to control the dollar money multiplier and raising the relative attractiveness of Lebanese pound deposits. Although a ceiling is imposed on the amount of dollardenominated deposits that banks can on-lend-a measure that potentially dampens growth in the money supply-it does little to diminish the relative attractiveness of U.S. dollar deposits.

Most important, provision of a stable macroeconomic and financial environment would aid the reflow of wealth into pound-denominated assets, and the Lebanese authorities have made a useful start in this area. In this sense, much of the discussion over the appropriateness of full dollarization or de-dollarization places the monetary cart before the fiscal horse. Clearly, it is very important that Lebanon's large fiscal deficits, as the root cause of its inflation, depreciation, currency substitution, and dollarization, be reduced substantially and as quickly as possible. 


\section{Estimating Money Demand in Lebanon}

E stimating money demand for Lebanon has been made more difficult by the war-induced increase in currency substitution that occurred during the sample period. Empirical tests suggest several promising monetary aggregates that result in a stable money demand function, giving the Lebanese monetary authorities scope to influence future developments in both the price level and income. These results provide econometric evidence that, despite the economic turmoil of the civil war, stable equilibrium relationships do exist in the long-run series for money, prices, and output in Lebanon. ${ }^{36}$ Specifically, in the context of monetary programming, the results also suggest that the domestic component of total liquidity is preferred as the monetary target for money denominated in Lebanese pounds, and the foreign component of total liquidity is preferred as the monetary target for dollar-denominated money.

\section{Dollarization and the Definition of Money}

U.S. dollars in circulation in Lebanon serve as both a store of value and a medium of exchange. However, the substitutability between Lebanese pounds and U.S. dollars can be gauged only for dollar-denominated bank deposits and pound-denominated money (currency plus deposits). As previously mentioned, dollar currency in Lebanon is unobservable, and no official data exist.

Notwithstanding these difficulties, for purposes of monetary targeting by the Lebanese authorities to achieve desired outcomes for key economic variables, a necessary requirement is that a stable demand relationship exist between the monetary aggregate of choice and these variables. In this sense, a suitable monetary aggregate is defined as one with a stable money demand function, and several possible candidates are examined here: base money $(B M)$, narrow money $(M 1)$, foreign currency deposits $(F C D)$, the

\footnotetext{
${ }^{36}$ Earlier estimates of Lebanese money demand were carried out by Short (1981) and Saïdi (1984b).
}

Lebanese pound component of $M 2(M 2 L L)$, and total liquidity, including $F C D(M 2)$.

\section{Behavior of Velocity}

The wide variation in the velocity of the five monetary aggregates over the sample period is depicted in Chart 9. Velocity for all five aggregates declined during $1964-82$, thereafter rising. The fall in the velocity of $B M$ and $M 1$ after 1974 reflects the increase in Lebanese pound currency holdings in the early years of the civil war. The sharp spike in the velocity of $B M$, $M 1$, and $M 2 L L$ around 1986 reflects the abandonment by Lebanese residents of pound-denominated money at this time, and is matched by an increase in dollardenominated deposits both inside and outside Lebanon. For most of the sample period, foreign currency deposits were increasingly used to avoid the opportunity cost of holding pound-denominated assets in a high-inflation environment. ${ }^{37}$

The time path of the magnitudes of the various monetary aggregates is shown in Chart 10 and mirrors the results of Chart 9. Of greatest interest is the rapid relative growth of foreign currency deposits, particularly during 1977-80 and 1982-86. A clear picture of the composition of total liquidity (money plus quasi money) is given in Chart 11, which demonstrates the sharp collapse (rapid rise) in the relative weight of pound-denominated (dollar-denominated) deposits in total deposits after 1985 and a similar fall in the share of Lebanese pound currency holdings at that time. After 1987, the share of pound-denominated assets in total liquidity began to rise, but there is evidence of hysteresis in this process; between 1991 and 1993, the share of such assets in total liquidity remained constant

${ }^{37}$ The movements in velocities depicted in Chart 9 follow the typical U-shaped pattern described by Bordo and Jonung (1987). In Lebanon, the pre-1982 downward path of most income velocities reflects both the introduction of modern banking and payments systems and the desire of Lebanese residents to hold their wealth in liquid forms in the early years of the civil war. After 1982, they began to economize on pound-denominated money balances (and to hold their wealth in dollar-denominated and nonmoney forms) in reaction to the likelihood of a protracted conflict and high domestic inflation. 


\section{Chart 9. Velocity of Monetary Aggregates}

14

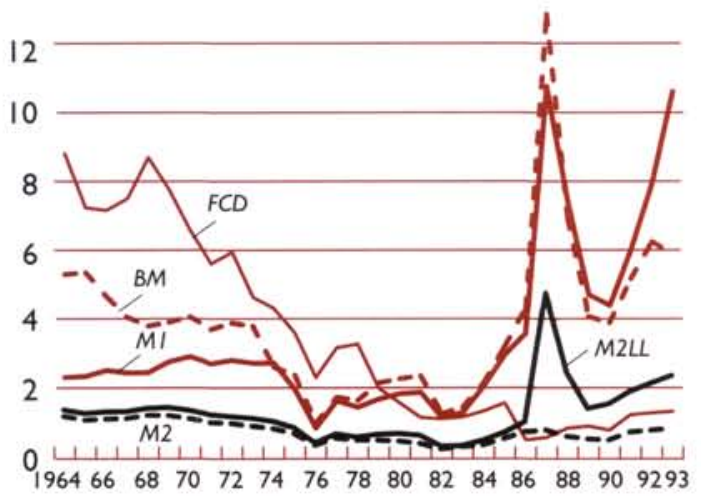

Sources: Bank of Lebanon; International Monetary Fund, International Financial Statistics; and IMF staff estimates.

at about 40 percent, far below the 1985 level of about 70 percent.

\section{Specifications of Money Demand}

Two simple models of money demand are posited. The first model follows a standard specification:

$$
M_{t}=\beta_{0}+\beta_{1} P_{t}+\beta_{2} y_{t}+\beta_{3} \pi_{t}+\beta_{4} D+\varepsilon_{t},
$$

where $M_{t}$ is the log of the nominal monetary aggregate (alternatively defined as above); $P_{t}$ is the log of the price level; $y_{t}$ is the log of real income; $\pi_{t}$ is expected inflation (proxied by the difference of the log of the actual price level); $D$ is a deterministic dummy variable to account for the civil war years of 1975-90 (taking a value of unity in those years and zero elsewhere); and $\varepsilon_{t}$ is the error term. In this specification, money demand is expected to increase with rises in the general level of prices and real incomes and to fall with increases in the rate of change of the price level (which raises the opportunity cost of holding money, particularly currency holdings, which have a zero nominal rate of return). ${ }^{38}$ The deterministic shift parameter is included to account for the shock to money demand caused by the civil war. (See Giovannini and Turtelboom (1992) and Orden and Fisher (1990) for uses of this approach.) $)^{39}$ The second model is the constantvelocity model of money demand, where the nominal monetary aggregate is deemed to have a stable rela-

\footnotetext{
${ }^{38} \mathrm{The}$ demand for FCD and $M 2$ is expected to be positively and negatively related, respectively, to the Lebanese rate of inflation, as then individuals would switch their demand for money from pounddenominated currency and deposits, which bear the inflation tax, to their dollar-denominated equivalents, which do not.

${ }^{39}$ The specification in equation (1) excludes consideration of capital flight and repatriation. To the extent that these are strongly related to inflation and exchange rate movements, their exclusion could lead to biased parameter estimates.
}

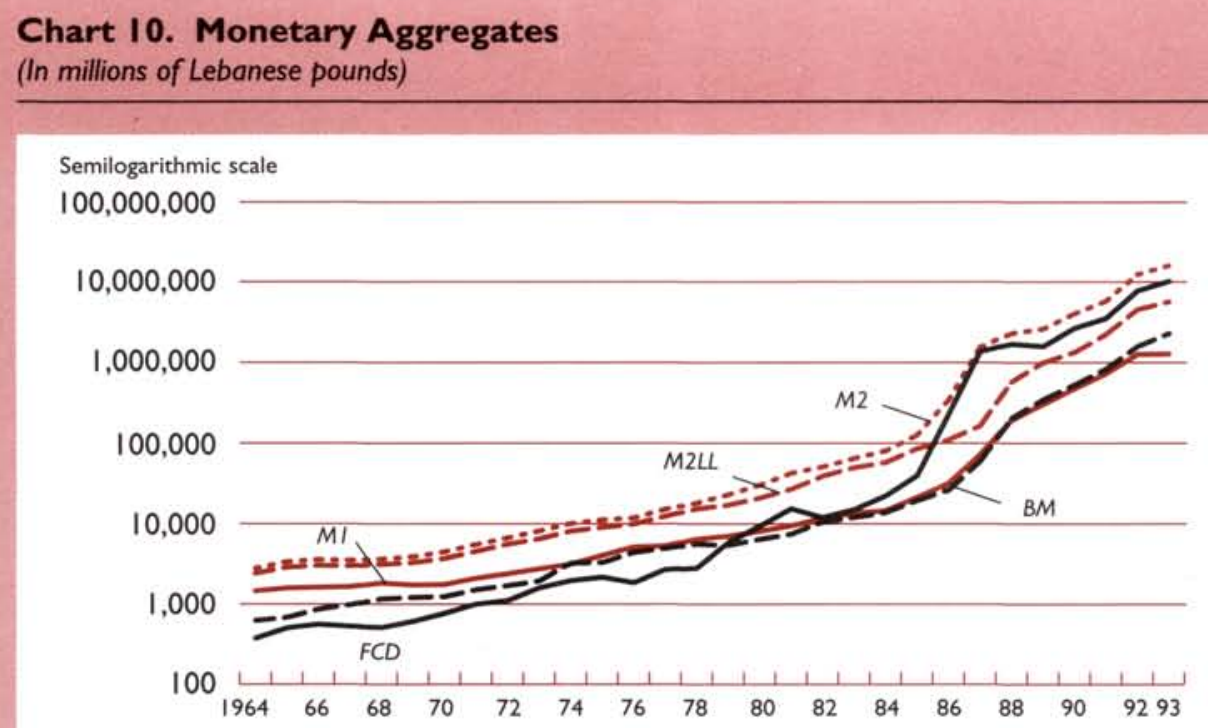

Sources: Bank of Lebanon; and International Monetary Fund, International Financial Statistics. 


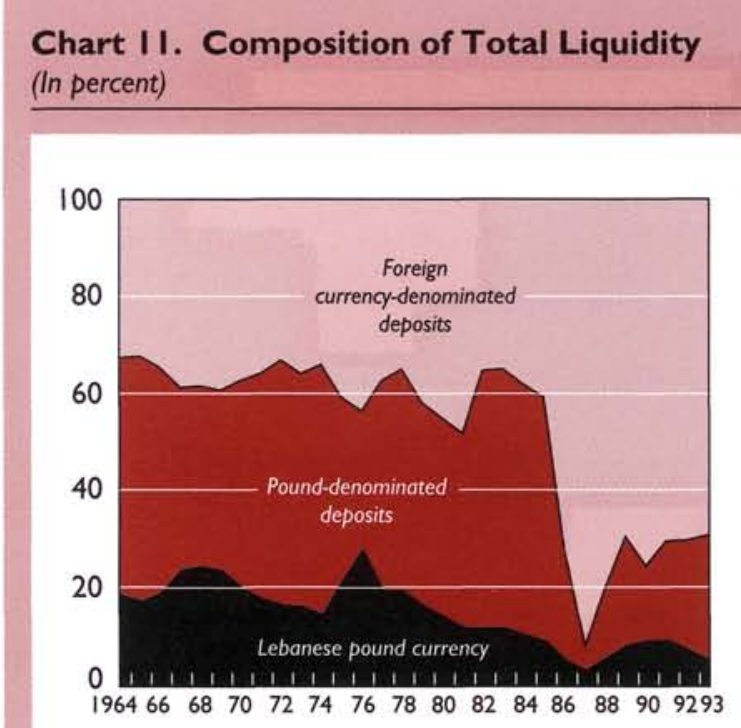

Sources: Bank of Lebanon; International Monetary Fund, International Financial Statistics; and IMF staff estimates.

tionship with nominal GDP. It is important to note that any such stability in the income velocity of money requires that the data not reject the restriction of a unit elasticity of money demand with respect to output and prices (see Orden and Fisher (1990)).

\section{Unit Root Tests for Stationarity ${ }^{40}$}

Recent developments in time-series econometrics have made clear that models that ignore the nonstationarity of individual series will generate spurious regression results and that if the (similarly integrated) ${ }^{41}$ series in any given model are cointegrated, 42 then linear combinations of these variables will converge to stationary long-run equilibrium relationships.

\footnotetext{
${ }^{40}$ Stationarity of a series implies that graphs of a realization of a time series over two equal-length time intervals should exhibit similar statistical characteristics. Stationary series have a tendency to return to their original value after a random shock; the mean and variance of such a series do not change with the passage of time.

${ }^{41}$ Integration is the representation of a process as a sum of past shocks. A process is said to be integrated of order $d(I(d))$ if after differencing $d$ times the resulting process is stationary (denoted $I(0)$ ).

${ }^{42}$ Nonstationary unit root processes are characterized by time paths that exhibit trend movements, and the paths of such series would usually be expected to diverge from their original value over time. Variables with unit roots are characterized by fluctuations around a stochastic trend, with shocks leading to permanent movements in the series away from trend. However, if there are strong long-run linkages between a group of individual series so that a linear combination of them is stationary (stable), then the series are said to be cointegrated.
}

Stationarity can be achieved through (1) differencing the data; or (2) formulating a regression model with nonstationary variables, a linear combination of which produces stationary error terms, using the concept of cointegration. ${ }^{43}$

To ensure that all variables in an equation such as (1) form a cointegrating relationship with a stationary error term, it is necessary to establish that all individual time series are of the same data-generating process (or order of integration) $I(d), d>0$, and that the residual term in (1) is stationary, thus minimizing the probability of obtaining spurious results (Granger (1986)). ${ }^{44}$ In testing whether or not there is any long-run relationship between the variables of interest, the cointegration technique makes use of the fact that nonstationary series generally evolve over time. A stationary error term means that the variables have tended to move together over the long run and that if an exogenous shock drives the variables out of equilibrium, then there is a tendency for them to move together again. In this sense, cointegration of money, income, and prices implies that these variables move together over time and revert to an equilibrium relationship in response to shocks.

Phillips-Perron (1988) integration tests were applied to the following series, which were also subsequently used in the cointegration analysis: real pound-denominated GDP $(y L L)$; real dollar-denominated GDP $(y \$)$; the Lebanese consumer price index $(P)$, the U.S. consumer price index $\left(P^{*}\right)$; the Lebanese inflation rate $(\pi)$; the U.S. inflation rate $\left(\pi^{*}\right)$; the rate of interest on dollar deposits, proxied by the six-month U.S. dollar deposit LIBOR rate (LIBOR6A); the Lebanese discount rate $(D I S R L B N)$; the various Lebanese nominal monetary aggregates: base money $(B M)$, narrow money $(M 1)$, dollar-denominated deposits $(F C D \$)$, the Lebanese pound component of broad money $(M 2 L L)$, broad money including $F C D$, valued in Lebanese pounds $(M 2)$; and their real counterparts: $B M-P, M 1-P, F C D \$-$ $P^{*}, M 2 L L-P$, and $M 2-P$. All monetary data were taken either from the International Financial Statistics data base or from the BDL, and the real sector data were supplied by IMF staff and BDL estimates, with interpolations carried out where necessary (see Section II for details).

The results of the stationarity tests for 1964-93, presented in Table 10, clearly indicate that all of the variables tested are not stationary. Further, most of

\footnotetext{
${ }^{43} \mathrm{~A}$ problem with the Box-Jenkins approach of differencing the data to overcome the spurious regression problem is that such a procedure disregards the important long-run relationships among the levels of the series, which are commonly derived from economic theory.

${ }^{44}$ Note that data with a unit root will always be nonstationary and are denoted $I(1)$. Nominal GDP and other macroeconomic time series are typically not stationary, owing to the upward trend in the series.
} 


\section{Table 10. Phillips-Perron Tests for Stationarity, 1964-931}

\begin{tabular}{|c|c|c|c|c|c|}
\hline Series $^{2}$ & $\begin{array}{l}Z(\alpha) \\
(I)\end{array}$ & $\begin{array}{c}Z(t \alpha) \\
(2)\end{array}$ & $\begin{array}{c}Z(\Phi 3) \\
\text { (3) }\end{array}$ & $\begin{array}{c}Z(\alpha) \\
(4)\end{array}$ & $\begin{array}{c}Z(\tau \alpha) \\
(5)\end{array}$ \\
\hline$B M$ & -0.20 & -0.11 & 4.99 & 1.90 & 3.02 \\
\hline MI & -1.50 & -0.84 & 4.83 & 1.66 & 2.39 \\
\hline FCD\$ & -5.53 & -1.63 & 1.34 & -0.99 & -0.92 \\
\hline M2LL & -4.39 & -1.52 & 1.29 & -2.99 & -1.51 \\
\hline M2 & -0.51 & -0.35 & $9.46 *$ & 1.86 & 4.17 \\
\hline$B M-P$ & -3.84 & -1.66 & 2.86 & -2.44 & -0.91 \\
\hline$M /-P$ & -1.49 & -0.73 & 3.45 & 1.41 & 0.72 \\
\hline FCD\$-P & -6.26 & -1.78 & 1.53 & -1.86 & -1.11 \\
\hline M2LL-P & -3.62 & -1.32 & 1.77 & -2.84 & -0.94 \\
\hline$M 2-P$ & 5.36 & -1.50 & 1.11 & -0.19 & -0.40 \\
\hline$y L L$ & -12.09 & -2.76 & 3.49 & -10.63 & -2.45 \\
\hline$y \$$ & -9.28 & -2.00 & 1.94 & -7.67 & -1.99 \\
\hline p & -1.14 & -0.68 & 5.44 & 1.98 & 2.27 \\
\hline p* & -2.62 & -0.84 & 0.66 & -0.39 & -0.92 \\
\hline$\pi$ & -14.38 & -2.86 & 3.81 & -8.67 & -2.26 \\
\hline$\pi^{*}$ & -6.49 & -1.93 & 2.11 & -7.05 & -1.94 \\
\hline LIBOR6A & -5.18 & -1.42 & 1.68 & -6.65 & -1.68 \\
\hline DISRLBN & -8.32 & -2.15 & 2.15 & -0.84 & -0.57 \\
\hline RETFCD & -5.26 & -1.08 & 1.35 & -7.71 & -1.78 \\
\hline
\end{tabular}

Source: IMF staff calculations.

IThe Phillips-Perron (1988) tests are based on the following model for any variable $x: x_{t}=\beta t+\infty x_{t-1}+\varepsilon_{t}$. The test relies on rejecting a unit root $(\alpha=1)$ in favor of stationarity. The $\mathrm{H}_{0}: \alpha$ $=\mathrm{I}$ is tested by $Z(\alpha), Z(t \alpha)$; and $\alpha=1, \beta=0$ is tested by $Z(\Phi 3)$. The statistics in columns $3-5$ are computed by restricting the coefficient $\beta$ to be zero, and if the null hypothesis cannot be rejected (is not significant), then the series has a unit root. The (*) indicates significance at the 5 percent level. A finding of statistical significance means that the relevant null hypothesis can be rejected. All test statistics are calculated at a lag truncation order of three for the residual autocorrelations used in calculating the estimated residual variance. The statistics were similar for other lag lengths.

${ }^{2}$ All series (except for the interest rates) are in logs.

them do not contain a deterministic trend component, with the possible exception of $M 2$, which could well be due to measurement error arising from its exclusion of U.S. dollar currency in circulation. All the statistics testing for one unit root versus no unit roots are insignificant, indicating that the null hypothesis of a unit root cannot be rejected. Alternatively, all the statistics testing for two unit roots versus at most one unit root are significant (not reported here). Hence, all series are integrated of order one (I(1)), and the logs of the levels of the individual time series are nonstationary. This finding has two important implications. First, shocks to the economic system (such as the civil war) will move the above variables permanently above or below any previous trend in their evolution. Second, the level form of these variables can be modeled in a cointegrating equation and tested for the existence of a long-run relationship.
In later sections, the Engle-Granger (1987) procedure is applied to the cointegrating vector that contains the real monetary aggregates (thus imposing homogeneity, a unit price elasticity). The cointegrating vector is then further restricted by imposing a value of unity on the coefficient on real income, thus regressing the nominal monetary aggregates on nominal income. The validity of these restrictions is then tested using the values of the Phillips-Ouliaris cointegration tests. Note that in selecting the appropriate variables to enter the vector of cointegrating variables, t-statistics from ordinary least-squares (OLS) cointegrating regressions should not be relied upon, as the estimated standard errors are biased and inconsistent (see Engle and Granger (1987)). Instead, it is better to use the cointegration test results to guide both the selection of explanatory variables and an assessment of the validity of restrictions. (See also Muscatelli and Papi (1990) on this point.)

\section{Money Demand: Cointegration Results and Policy Implications}

For each of the five monetary aggregates, the preferred OLS results from the cointegrating regressions are listed below for 1964-93.45 All analyses were carried out with data in logarithms and with a linear functional form assumed. A deterministic dummy variable is used to control for the effects of the civil war years of 1975-90. The best results for each monetary aggregate are given below, with $\left(^{*}\right)$ denoting that the $Z(\alpha)$ test statistic of Phillips and Ouliaris (1990) is significant: ${ }^{46}$

$$
\begin{gathered}
B M-P=1.67+0.79 y-1.20 \pi+0.77 D \\
R^{2}=0.782, Z(\alpha)=-25.82^{*} \\
M 1-P=-2.77+1.12 y-1.47 \pi+0.77 D \\
R^{2}=0.775, Z(\alpha)=-29.69 * \\
F C D \$=-7.78+2.22 P^{*}+0.64 y \$ \\
+0.17 \pi+0.32 D \\
R^{2}=0.978, Z(\alpha)=-18.99 \\
M 2 L L-P=0.38+0.96 y-1.31 \pi+0.89 D \\
R^{2}=0.801, Z(\alpha)=-23.73 *
\end{gathered}
$$

${ }^{45} \mathrm{OLS}$-based static cointegrating regressions involving I(1) variables are asymptotically consistent, regardless of measurement error or simultaneity bias. This is the "super-consistency" result of Stock (1987)-see also McDermott (1990).

${ }^{46}$ The inclusion of a deterministic dummy variable in the cointegrating regression would be expected to alter the true critical values of the cointegration test. However, the civil war years of 1975-90 represent half of the 1964-93 sample period, a fraction that also coincides with the global minimum of the function that corrects the asymptotic critical values. 


$$
\begin{gathered}
M 2=-1.74+1.01 P+0.80 y-0.06 \pi+0.77 D \\
R^{2}=0.993, Z(\alpha)=-15.84
\end{gathered}
$$

The critical values for the $Z(\alpha)$ tests are given in Phillips and Ouliaris (1990), where the null hypothesis of no cointegration is rejected if the error term from the cointegrating regression is stationary. ${ }^{47}$ The results for each of the monetary aggregates are examined below.

The results for the regressions on real $B M$, real $M 1$, and real $M 2 L L$ of equations (2), (3), and (5) indicate that a cointegrating (long-run) relationship among the money, output, price, and inflation series exists, provided that a single deterministic shift variable is included in the model to account for the effects of the civil war on money demand. In equations (2), (3), and (5), the $Z(\alpha)$ statistic is significant at the $0.075,0.05$, and 0.010 percent levels, respectively. As expected, the coefficient on real output in each of the three equations is positive, and that on inflation is negative, indicating that holding fiat money and bank deposits has high opportunity costs in times of inflation. For example, long-run $M 2 L L$ demand has a coefficient on real income of 0.96 , indicating that a 1 percent increase in real income raises real $M 2 L L$ by 0.96 percent.

As noted above, all regressions were run after imposing homogeneity. This imposes a unit elasticity on the responsiveness of money demand to changes in the price level and was not rejected by the data in equations (2), (3), and (5). That is, there is a proportional relationship between increases in money stocks and changes in the price level for these monetary aggregates. No cointegrating relationship was found in equations (4) and (6). For equations (4) (and (6)), the coefficient on $\pi$ was positive (and barely negative), as expected, reflecting the advantages of holding dollardenominated money in the presence of pound-based inflation. 48

While the coefficients on the variables in the cointegrating regression have the appropriate signs, the results for $M 2$ and $F C D \$$ indicate that the relevant monetary aggregate and $y$ (or $y \$), P\left(\right.$ or $\left.P^{*}\right), \pi$, and $D$ do not form a cointegrating vector-there is no stable long-run relationship among these variables. In particular, the result for $M 2$ can be explained by the wide variance in the holdings of dollar-denominated deposits and dollar currency by the Lebanese during 1964-93, and by the fact that data on dollar currency in

${ }^{47}$ The Phillips-Ouliaris test is preferable to the augmented DickeyFuller tests and Durbin-Watson tests more commonly reported in the literature because it is robust to a wide variety of serial correlation and time-dependent heteroscedasticity. Similar advantages are found for the Phillips-Perron test for stationarity, when compared with alternative tests. The advantages of the Phillips-Ouliaris test are even greater when the researcher, from economic theory, has knowledge of the appropriate variables of the cointegrating relationship.

${ }^{48} \mathrm{Both} F C D \$$ and $y \$$ are valued in dollars in equation (4), and at end-1993 about 70 percent of $M 2$ was composed of dollar-denominated bank deposits. circulation are unavailable, which increases the probability of measurement errors.

Nominal interest rates were found not to be important in any of the five cointegrating vectors and were consequently excluded. This result is not unexpected, given that government and financial market regulation constrained interest rates below the market rate for much of the sample period. Similarly, foreign interest rates (adjusted for expected depreciation of the exchange rate) also proved to be unsatisfactory. The fact that the income velocity of money is relatively unaffected by interest rate movements should also be expected given that deposits in broad money aggregates earn interest, which will presumably adjust in line with returns on nonbroad money assets. 49

As to the question of which real monetary aggregate exhibits the more robust long-run relationship with the explanatory variables, Banerjee and Dolado (1986) show that although the estimates of the cointegrating regression are consistent, they are subject to a finite sample bias, and a general guide is that the bias is inversely related to the $R^{2}$ statistic of any given equation. Accordingly, under this rule, $M 2 L L$ would be ranked ahead of $B M$ and $M 1$ in terms of a stable longrun money demand function.

The results for those monetary aggregates where the assumption of a unit elasticity on price and income was accepted $(B M, M 2 L L$, and $F C D \$)$ are shown below, with $\left(^{*}\right)$ again denoting that the $Z(\alpha)$ test statistic of Phillips and Ouliaris (1990) is significant:

$$
\begin{aligned}
& B M-P-y=-1.30-1.25 \pi+0.80 D+0.003 T \\
& R^{2}=0.780, Z(\alpha)=-28.73^{*} \\
& M 2 L L-P-y= 0.20-1.34 \pi+0.89 D+0.002 T \\
& R^{2}= 0.795, Z(\alpha)=-24.37^{*} \\
& F C D \$-P^{*}-y \$=-2.72+0.41 \pi+0.53 D+0.068 T \\
& R^{2}=0.928, Z(\alpha)=-22.15^{*}
\end{aligned}
$$

For $B M$ and $M 2 L L$, there is evidence of a long-run relationship between $(M-P-y), \pi, D$, and $T$ as the above joint restriction on the cointegrating vector was not rejected by the Phillips-Ouliaris test statistic (the $Z(\alpha)$ statistic is significant at the 0.05 and 0.10 percent level, respectively, in equations (7) and (8)). In equation (9), $F C D \$$ also evidences a long-run relationship with the

${ }^{49}$ The only domestic interest rate series available for the entire 1964-93 sample period is the Lebanese discount rate (DISRLBN), and the LIBOR on six-month deposits (LIBOR6A) was used to measure domestic returns on U.S. dollar deposits. Other rates of return were not used owing to a lack of data; International Financial Statistics data on rates of return on government bonds are available only from 1979, and interest rates on term deposits only from 1982. The variable RETFCD, which represents the log of the LIBOR6A rate less the depreciation of the LL/US\$ exchange rate, was also constructed and tested in all regressions. It was not accepted as an appropriate explanatory variable of money demand for any of the five monetary aggregates. 
variables in its cointegrating vector, as again the joint restriction of a unit elasticity on $P^{*}$ and $y \$$ was not rejected by the $Z(\alpha)$ test statistic, which was significant at the 0.125 percent level.

There is evidence of a long-run proportional relationship between these nominal monetary aggregates and nominal income, with the $R^{2}$ statistic again indicating that the strength of this relationship (among pounddenominated monies) is relatively greater for $M 2 L L$ than for $B M$. It should be noted that while the trend rate of growth of demand for $B M$ and $M 2 L L$ is quite low at 0.3 percent and 0.2 percent a year, respectively, for $F C D \$$ there is a trend growth in demand of a sizable 6.8 percent a year. These reflect the replacement of the Lebanese pound by the U.S. dollar as the preferred form of money in Lebanon over the sample period. Accordingly, for $B M, M 2 L L$, and $F C D \$$, the adjusted income velocity of money is stationary over the 1964-93 period.

The use of a deterministic trend term in equations (7) to (9) controls for the effects of financial innovation on money demand in Lebanon. ${ }^{50}$ In this sense, the "adjusted" income veiocity of, for example, FCD\$ is stationary around a trend. It is "adjusted" in that, after controlling for the effects of the war, expected inflation, and financial innovation on money demand, $F C D \$$ velocity is stationary. In other words, the income velocity of money is not constant but is stable around a trend and will revert to that trend following a shock to money demand. The rationale for the inclusion of a trend term in explaining the demand for $F C D \$$ and the other money aggregates is quite strong, given the wholesale changes in the process of Lebanese financial intermediation that accompanied the country's abandonment of the Lebanese pound and the embracing of the U.S. dollar as the dominant medium of exchange, store of value, and even unit of account. ${ }^{51}$

The above findings for $M 2 L L$ and $F C D \$$ provide the basis for the use of these monetary aggregates as nominal anchors in support of the achievement of price stability and output growth targets in Lebanon. In any operational use of such aggregates, the monetary authorities could use $M 2 L L$ to target growth in pounddenominated money and $F C D \$$ to target growth in dol-

\footnotetext{
${ }^{50}$ Work by Arrau and others (1991) also recommends that examinations of money demand take account of the impact of innovations in the process of financial intermediation.

${ }^{51}$ The Lebanese financial system between 1964 and 1993 has been characterized by growing dollar-based monetization; the BDL's introduction and regular use in the 1980 s of treasury bills as a new type of borrowing instrument resulted in a shift in portfolio preferences; and a gradual shift to dollar-based lending for domestic investment occurred, each of which took time for the banking public to adapt to. Muscatelli and Papi (1990) argue that whether trend variables are necessary in money demand equations is essentially an empirical question-one that has been answered in the affirmative here by the Phillips-Ouliaris test.
}

lar-denominated money. Accordingly, the former monetary aggregate would be increased in line with the growth of Lebanese GDP valued in Lebanese pounds, the latter with growth in Lebanese GDP valued in dollars. For a constant LL/US\$ exchange rate, growth in the two monetary aggregates would be the same. However, if the Lebanese pound appreciates (depreciates) against the U.S. dollar, then that implies a relatively slower (faster) rate of growth of the dollar component of Lebanese broad money when compared with the constant exchange rate case..$^{52}$ An implication of this result for any Lebanese monetary program is that when the Lebanese pound appreciates against the U.S dollar, growth of broad money, including foreign currency deposits in Lebanese pounds (M2), will be less than the growth of GDP in Lebanese pounds. When the Lebanese pound depreciates against the U.S. dollar, growth of $M 2$ (in Lebanese pounds) will exceed the growth of GDP in Lebanese pounds.

\section{Conclusions}

Stationarity and cointegration analyses of Lebanese monetary aggregates suggest that, after controlling for the effects of the 1975-90 civil war, the long-run demand for several definitions of money is determined by real income, prices, and domestic inflation. This finding of a stationary long-run relationship between money, prices, and output lends support to the possibility of effective monetary targeting in Lebanon. The data also reveal that discretion in the rate of growth of monetary aggregates can play an important role in controlling movements in the Lebanese price level, as the hypothesis of proportionality (homogeneity restriction) was not rejected for three $(B M, M 1$, and $M 2 L L)$ of the five monetary aggregates analyzed.

Traditionally, monetary authorities wish to target a monetary aggregate that has a predictable relationship with a nominal macroeconomic variable (such as the price level or nominal output) and that shows little responsiveness to changes in interest rates or movements in other economic variables. While three ( $B M$, $M 1$, and $M 2 L L$ ) of the five monetary aggregates failed to reject the restriction of a unit elasticity on the price level, $B M, F C D \$$, and $M 2 L L$ failed to reject the restriction of a unit elasticity on prices and income. It was found that demeaned and detrended $M 2 L L, B M$, and $F C D \$$ had stationary income velocities of money; following any given shock to money demand, the velocities revert to a constant mean and standard deviation

\footnotetext{
${ }^{52}$ The failure to find a stable income velocity of $M 2$, along with findings of stationary adjusted income velocities for the components of Lebanese $M 2$ (FCD $\$$ and $M 2 L L$ ), indicates that dollars are not likely to be close substitutes for pounds, particularly if, as is likely, foreign currency deposits are used primarily as a store of wealth.
} 
around a trend component that accounts for financial innovations affecting money demand in Lebanon. Hence, the hypothesis of an absence of any long-run relationship between nominal money and nominal Lebanese output is rejected for $M 2 L L, F C D \$$, and $B M$. This outcome provides scope for the Lebanese authorities to influence the path of the price level and output by establishing appropriate targets for each of the Lebanese pound and U.S. dollar components of broad money. In the context of monetary programming, the results also suggest that $M 2 L L$ is preferred to $B M$ as the monetary target for pound-denominated money, and FCD\$ is preferred as the monetary target for dollar-denominated money. 


\section{Exchange Rate Developments and Their Relationship to Inflation}

$T^{\prime}$ his section briefly reviews developments in the exchange rate of the Lebanese pound and provides an empirical study of the relationship between movements in the exchange rate and inflation. The evidence suggests that since the mid-1970s, the volatility of the Lebanese pound exchange rate has increased substantially, while the relationship between exchange rate movements and inflation has become more significant.

\section{Evolution of the Exchange Rate}

Lebanon, unlike most countries, has had a flexible exchange rate system since 1948. The monetary authorities have at times intervened in the foreign exchange market to stabilize short-term exchange rate fluctuations, but the exchange rate has largely been determined in an interbank system. ${ }^{53}$

In the early 1970s, Lebanon had a strong macroeconomic position. The economy in general registered relatively high rates of growth, low inflation, and overall balance of payments surpluses. This performance reflected small fiscal deficits and a liberal economic system. In these macroeconomic circumstances, coupled with a stable political environment, the LL/US\$ exchange rate registered an appreciating trend with limited volatility (Table 11, Chart 12 ). Specifically, during 1957-74, the Lebanese pound appreciated by about 35 percent against the U.S. dollar, and the maximum monthly increase and decrease in the LL/US\$ exchange rate were both limited to about 6 percent.

In the mid-1970s, with the onset of the civil war, the budgetary situation began to deteriorate and led to rising credit creation. While the overall balance of payments remained in surplus until the early 1980 s, the uncertain political environment and the pickup in inflation led to increased currency substitution in private portfolios and to speculative behavior. Reflecting these developments, in the period 1975-82, the LL/US\$ and

\footnotetext{
${ }^{53}$ For discussions of the evolution of the exchange rate system and exchange rate developments in Lebanon, see Badrud-Din (1984), Chami (1992), Makdisi (1987), Saïdi (1981, 1984b), and Spităller (1980).
}

nominal effective exchange rates depreciated steadily, and exchange rate volatility increased significantly. During 1975-82, the Lebanese pound depreciated by about 50 percent against the U.S. dollar, while the nominal effective exchange rate depreciated by about 40 percent. Moreover, the maximum increase and decrease in the monthly LL/US\$ rate rose to 8 percent and 11 percent, respectively.

During the second half of the 1980 s, the macroeconomic situation deteriorated significantly as the domestic conflict escalated. These developments contributed to an acceleration in inflation, a weakening in the external position and a rapid dollarization of the economy, and put significant downward pressure on the Lebanese pound. ${ }^{54}$ Meanwhile, with shifting expectations, the volatility of the exchange rate escalated sharply: during 1983-90, the Lebanese pound depreciated by close to 100 percent vis-à-vis the U.S. dollar and in nominal effective terms. The maximum increase and decrease in the monthly LL/US $\$$ rate rose to 43 percent and 20 percent, respectively.

After the adoption of the Taif Agreement, which provided a framework for settling the domestic conflict, the Government embarked upon a stabilization plan in 1991. The authorities, while not officially fixing the exchange rate, in effect attempted to link the Lebanese pound to the U.S. dollar without any formal commitment to maintaining a fixed exchange rate. Significant fiscal adjustment took place in 1991, with the fiscal deficit as a percentage of total expenditures declining to 56 percent from 84 percent in 1990 . However, a retroactive and sizable wage increase in December 1991 undermined the public's confidence in the Government's fiscal position, which led to a run on treasury bills. The flight from government paper, capital outflows, and a shift in private sector portfolios out of the Lebanese pound and into foreign currencies led to intense pressure on the exchange rate in the first half of 1992. The average exchange rate depreciated from

${ }^{54} \mathrm{The}$ foreign exchange reserves of the BDL declined from $\$ 1,051$ million in 1985 to $\$ 462$ million in 1986 and to $\$ 336$ million in 1987. The ratio of pound-denominated deposits to total deposits in the banking system declined from 65 percent in 1985 to about 8 percent in 1987. 


\section{Table II. Exchange Rate Indices and Inflation}

\begin{tabular}{|c|c|c|c|c|c|c|}
\hline Year & $\begin{array}{c}\text { LUSDR } \\
\text { (End of period) }\end{array}$ & $\begin{array}{c}\text { LLUS\$ } \\
\text { (End of period) }\end{array}$ & $\begin{array}{c}\text { LUUS\$ } \\
\text { (Period average) }\end{array}$ & $\begin{array}{c}\text { NEER } 1 \\
(1989=100)\end{array}$ & $\begin{array}{c}\text { REER }^{2} \\
(1989=100)\end{array}$ & $\begin{array}{l}\text { CPI Inflation } \\
\text { (In percent, } \\
\text { period average) }\end{array}$ \\
\hline 1948 & 3.60 & 3.60 & 3.60 & $\ldots$ & $\cdots$ & $\cdots$ \\
\hline 1949 & 3.25 & 3.25 & 3.25 & ... & $\ldots$ & $\cdots$ \\
\hline 1950 & 3.74 & 3.74 & 3.74 & $\cdots$ & $\cdots$ & $\ldots$ \\
\hline 1951 & 3.80 & 3.80 & 3.80 & $\cdots$ & $\cdots$ & 9.52 \\
\hline 1952 & 3.57 & 3.57 & 3.57 & $\cdots$ & $\cdots$ & - \\
\hline 1953 & 3.19 & 3.19 & 3.19 & $\ldots$ & $\ldots$ & -4.35 \\
\hline 1954 & 3.24 & 3.24 & 3.24 & $\ldots$ & $\ldots$ & -4.55 \\
\hline 1955 & 3.25 & 3.25 & 3.25 & $\ldots$ & $\ldots$ & - \\
\hline 1956 & 3.20 & 3.20 & 3.20 & $\ldots$ & $\ldots$ & 4.76 \\
\hline 1957 & 3.16 & 3.16 & 3.18 & $\ldots$ & $\ldots$ & 9.09 \\
\hline 1958 & 3.16 & 3.16 & 3.18 & $\cdots$ & $\ldots$ & 4.17 \\
\hline 1959 & 3.16 & 3.16 & 3.16 & $\cdots$ & $\cdots$ & 4.00 \\
\hline 1960 & 3.15 & 3.15 & 3.17 & $\cdots$ & $\cdots$ & 3.85 \\
\hline 1961 & 3.02 & 3.02 & 3.08 & $\ldots$ & $\ldots$ & - \\
\hline 1962 & 3.06 & 3.06 & 3.01 & $\ldots$ & $\ldots$ & -3.70 \\
\hline 1963 & 3.08 & 3.08 & 3.10 & $\ldots$ & $\ldots$ & 3.85 \\
\hline 1964 & 3.08 & 3.08 & 3.07 & $16,639.41$ & 133.50 & 3.70 \\
\hline 1965 & 3.07 & 3.07 & 3.07 & $16,656.54$ & 132.60 & 3.57 \\
\hline 1966 & 3.17 & 3.17 & 3.13 & $16,361.04$ & 129.14 & - \\
\hline 1967 & 3.13 & 3.13 & 3.20 & $16,007.39$ & 127.80 & 3.45 \\
\hline 1968 & 3.18 & 3.18 & 3.16 & $16,540.14$ & 127.06 & - \\
\hline 1969 & 3.25 & 3.25 & 3.25 & $16,129.29$ & 124.66 & 6.67 \\
\hline 1970 & 3.25 & 3.25 & 3.27 & $16,051.88$ & 118.29 & - \\
\hline 1971 & 3.43 & 3.16 & 3.23 & $15,963.94$ & 113.19 & - \\
\hline 1972 & 3.27 & 3.01 & 3.05 & $15,739.47$ & 110.85 & 6.25 \\
\hline 1973 & 3.03 & 2.51 & 2.61 & $16,926.00$ & 115.56 & 5.88 \\
\hline 1974 & 2.82 & 2.30 & 2.33 & $19,523.16$ & 128.87 & 11.11 \\
\hline 1975 & 2.84 & 2.43 & 2.30 & $19,103.22$ & 122.13 & 10.00 \\
\hline 1976 & 3.40 & 2.93 & 2.87 & $16,909.59$ & 125.53 & 27.27 \\
\hline 1977 & 3.64 & 3.00 & 3.07 & $15,526.27$ & 124.88 & 19.64 \\
\hline 1978 & 3.91 & 3.01 & 2.96 & $14,576.45$ & 120.94 & 10.45 \\
\hline 1979 & 4.29 & 3.26 & 3.24 & $12,755.10$ & 120.35 & 22.97 \\
\hline 1980 & 4.65 & 3.65 & 3.44 & $12,051.00$ & 125.64 & 24.18 \\
\hline 1981 & 5.38 & 4.63 & 4.31 & $11,371.48$ & 127.64 & 19.47 \\
\hline 1982 & 4.20 & 3.81 & 4.74 & $11,614.54$ & 142.36 & 18.52 \\
\hline 1983 & 5.75 & 5.49 & 4.53 & $13,240.38$ & 163.23 & 6.88 \\
\hline 1984 & 8.71 & 8.89 & 6.51 & $10,207.38$ & 140.38 & 18.13 \\
\hline 1985 & 19.88 & 18.10 & 16.42 & $4,201.67$ & 93.66 & 69.31 \\
\hline 1986 & 106.42 & 87.00 & 38.37 & I,68I.36 & 71.64 & 95.32 \\
\hline 1987 & 645.49 & 455.00 & 224.60 & 304.88 & 74.46 & 487.13 \\
\hline 1988 & 713.22 & 530.00 & 409.23 & 116.59 & 70.55 & 154.97 \\
\hline 1989 & 663.65 & 505.00 & 496.69 & 100.00 & 100.00 & 72.20 \\
\hline 1990 & $1,197.88$ & 842.00 & 695.09 & 66.57 & 107.28 & 68.82 \\
\hline 1991 & $1,257.35$ & 879.00 & 928.23 & 49.01 & 114.29 & 51.46 \\
\hline 1992 & $2,527.25$ & $1,838.00$ & $1,712.79$ & 28.69 & 142.11 & 119.99 \\
\hline 1993 & $2,350.16$ & $1,711.00$ & $1,741.36$ & 27.41 & 170.08 & 29.11 \\
\hline
\end{tabular}

Source: International Monetary Fund, International Financial Stotistics.

INominal effective exchange rate. Decline implies depreciation.

2Real effective exchange rate. Decline implies depreciation.

LL 879 per US $\$ 1$ in January 1992 to LL $2,527.8$ per US $\$ 1$ by September 1992, and inflation soared.

In the last quarter of 1992 , the authorities adopted a package of stabilization measures designed to reduce the fiscal deficit and credit creation and to re-establish financial stability. The consequent return of confidence, attractive interest rates on Lebanese government securities, and favorable prospects in the real estate and construction sectors all led to a surge in capital inflows, which put upward pressure on the exchange 


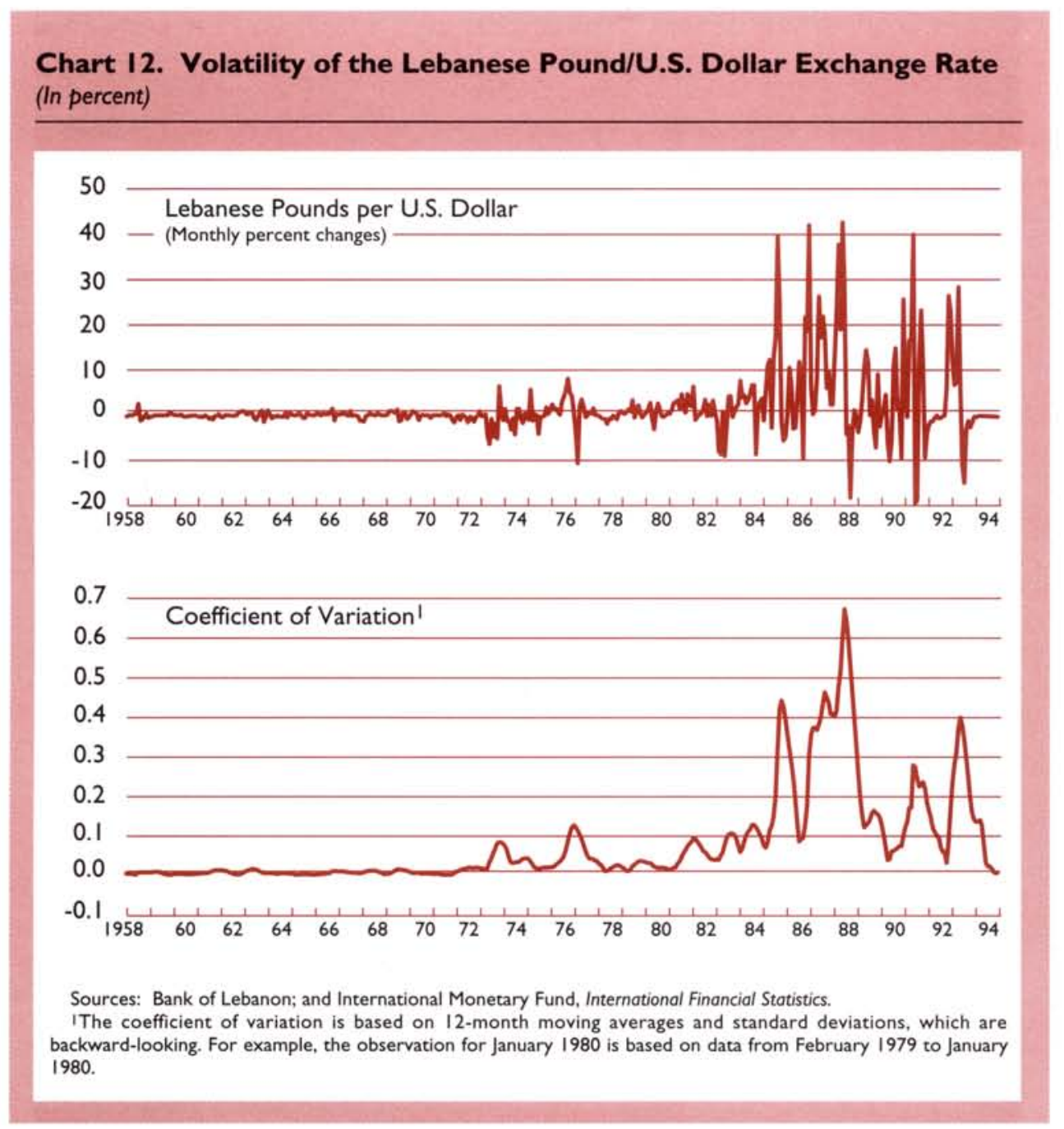

rate. ${ }^{55}$ In the circumstances, the authorities intervened in the foreign exchange market to moderate the appreciation of the Lebanese pound and to build up further official foreign exchange reserves. Despite this intervention, the Lebanese pound appreciated by about 30 percent against the U.S. dollar between October 1992 and March 1994, thereby reversing the sharp depreciation that took place in the third quarter of 1992. Not surprisingly, starting in 1993, there was a sharp decline in exchange rate volatility.

The sizable movements in inflation and the exchange rate have led to significant swings in the real effective exchange rate of the Lebanese pound, with the most important developments occurring in the 1980s. During 1964-81, in spite of large movements in

${ }^{55}$ Reliable data on capital flows for Lebanon are not available. Nevertheless, some inference about the size of such flows may be drawn from changes in the foreign exchange reserves of the BDL, which in 1993 rose by about 50 percent to $\$ 2.2$ billion. the LL/US\$ exchange rate and in the nominal effective exchange rate, the real effective exchange rate remained relatively stable; in 1981 it was only about 4 percent more depreciated than its level of 1964 (Chart 13). ${ }^{56}$ However, the real effective exchange rate depreciated by 57 percent between 1983 and 1988, although it subsequently appreciated by about 70 percent between 1989 and $1993 . .^{57}$ In spite of these very large swings, the real effective exchange rate in 1993 was only about 32 percent more appreciated than its level of 1974. During 1993, the Lebanese pound appreciated

\footnotetext{
${ }^{56}$ In Charts 13-16, a decline in the exchange rate indices indicates a depreciation.

${ }^{57}$ Indeed, any judgment on the degree of appreciation of the real effective exchange rate depends on the choice of the base year. For example, using 1983 (the year after the Israeli incursion) as the reference year would indicate that by 1993 the real effective exchange rate had appreciated by only 4 percent. In addition, it should be noted that the CPI data for Lebanon are not official and may not be highly reliable.
} 


\section{Chart 13. Real and Nominal Effective Exchange Rates, 1964-93}

$(1980=100)$

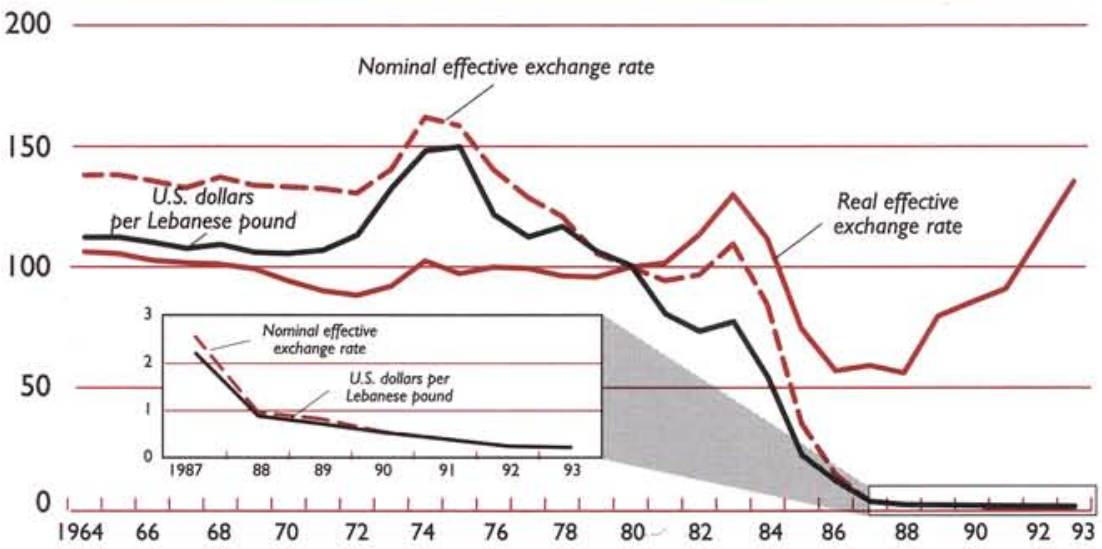

Source: International Monetary Fund, International Financial Statistics.

more or less steadily against the U.S. dollar, but domestic prices did not follow pari passu the movements in the exchange rate. Consequently, the real effective rate appreciated sharply (Chart 14).

However, inferences about Lebanon's external competitiveness based on movements in the real effective

\section{Chart 14. Real and Nominal Effective Exchange Rates, 1989-93 \\ $(1980=100)$}

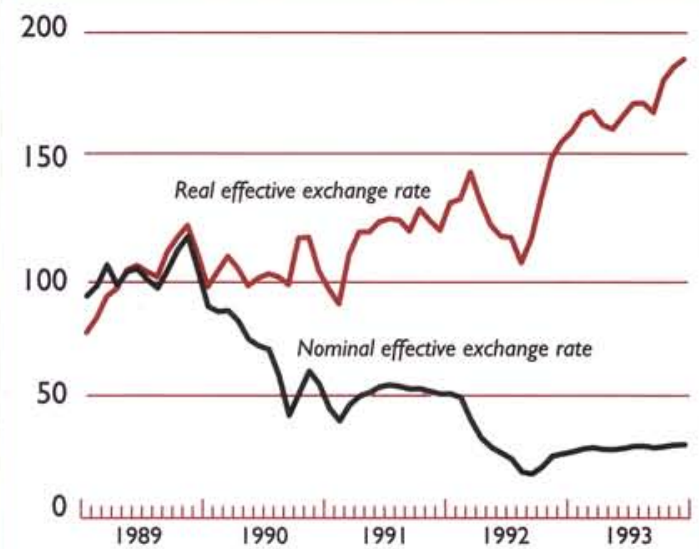

Source: International Monetary Fund, Information Notice System. exchange rate reported above should be drawn with caution. In addition to the limitations of indicators based on aggregate consumer price indices for assessing the profitability related to the production of traded goods, other indicators would present a somewhat different picture of Lebanon's external competitiveness. ${ }^{58}$ For example, the available information indicates that real labor costs in Lebanon have declined dramatically since 1974 (Table 12); during 1974-93, real minimum wages in terms of the Lebanese pound and the U.S. dollar are estimated to have declined by 86 percent and 43 percent, respectively.

The dearth of comparable data on wages, unit costs, and other indicators of international competitiveness precludes a systematic assessment of Lebanon's international competitiveness in relation to other countries in the Middle East region. Nevertheless, it is useful to compare movements in the Lebanese nominal and real effective exchange rates with those for a number of countries in the region-Egypt, Israel, Jordan, Syria, and Turkey (Charts 15 and 16). ${ }^{59}$ Taking 1980 as the base year, while Lebanon's nominal effective

\footnotetext{
${ }^{58}$ These limitations include the absence of perfect substitutability of traded goods; the shortcomings of aggregate price indices in reflecting factor rewards, owing in part to different patterns of productivity growth in various countries; price controls and subsidies; and noninclusion of intermediate goods in consumer price indices. On the limitations of CPI-based measures of the real exchange rate, see Lipschitz and McDonald (1991), and Marsh and Tokarick (1994).

${ }^{59} \mathrm{All}$ exchange rate indices were computed using consumer prices.
} 
Table 12. Legal Minimum Wages

\begin{tabular}{|c|c|c|c|c|c|}
\hline Year & $\begin{array}{l}\text { Minimum Wage } \\
\text { in Lebanese Pounds } \\
\text { (Annual earnings) }\end{array}$ & $\begin{array}{l}\text { Real Minimum } \\
\text { Wage in } \\
\text { Lebanese Pounds } \\
\text { (Constant 1974) }\end{array}$ & $\begin{array}{l}\text { Real Minimum } \\
\text { Wage in } \\
\text { Lebanese Pounds } \\
(1974=100)\end{array}$ & $\begin{array}{l}\text { Minimum Wage } \\
\text { in U.S. Dollars }\end{array}$ & $\begin{array}{c}\text { Minimum Wage } \\
\text { in U.S. Dollars } \\
(1974=100)\end{array}$ \\
\hline 1974 & 3,300 & 3,300 & 100 & 1,418 & 100 \\
\hline 1975 & 3,720 & 3,385 & 103 & 1.621 & 114 \\
\hline 1977 & 4,980 & 2,948 & 89 & 1,623 & 114 \\
\hline 1980 & 8,100 & 2,842 & 86 & 2,358 & 166 \\
\hline 1981 & 9,600 & 2,822 & 86 & 2,225 & 157 \\
\hline 1982 & 11,100 & 2,751 & 83 & 2,347 & 166 \\
\hline 1983 & 13,200 & 3,051 & 92 & 2.915 & 206 \\
\hline 1984 & 15,120 & 2,971 & 90 & 2,322 & 164 \\
\hline 1985 & 18,000 & 2,087 & 63 & 1,096 & 77 \\
\hline 1986 & 32,400 & 1,923 & 58 & 844 & 60 \\
\hline 1987 & 81,000 & 819 & 25 & 360 & 25 \\
\hline 1988 & 210,000 & 832 & 25 & 513 & 36 \\
\hline 1989 & 540,000 & 1,243 & 38 & 1,087 & 77 \\
\hline 1990 & 540,000 & 736 & 22 & 769 & 54 \\
\hline 1991 & 900,000 & 810 & 25 & 970 & 68 \\
\hline 1992 & $1,416,000$ & 579 & 18 & 827 & 58 \\
\hline 1993 & $1,416,000$ & 449 & 14 & 813 & 57 \\
\hline
\end{tabular}

Source: Bank of Lebanon.

exchange rate has depreciated significantly, its real effective exchange rate has appreciated by more than those of nearly all the other countries in the sample.

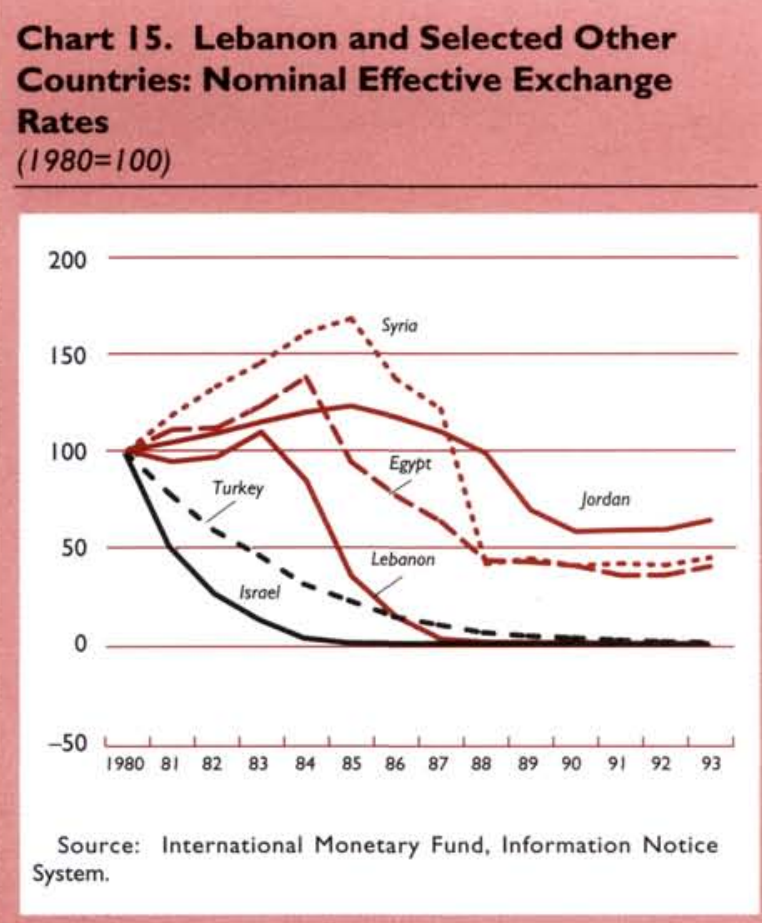

\section{Long-Term Relationship Between Exchange Rate Movements and Inflation}

Movements in the annual CPI and the LL/US\$ exchange rate during the periods $1951-80$ and 1975-93 are captured in Charts 17 and 18, respectively. While there was some co-movement between inflation and exchange rate movements during 1951-74, the nature of the relationship became tight and more contemporaneous after the start of the civil war. With increased political tensions, economic imbalances, and dollarization of the Lebanese economy, price-setting behavior became more closely affected by developments in the exchange rate. However, as shown in Chart 19, this relationship weakened in 1991. In particular, since the beginning of 1993 , exchange rate policy has been geared to maintaining a stable nominal rate, and movements in the price level have not affected the exchange rate.

To obtain statistical insight into the relationship between inflation and nominal exchange rate movements, a simple regression equation relating the differential between Lebanese and U.S. inflation rates to changes in the LL/US\$ exchange rate was estimated. 60

60The estimated regression equation was as follows:

$$
I N F D I F F_{t}=\alpha_{0}+\alpha_{1} \Delta e_{t}+u_{t},
$$

where INFDIFF, is the differential between Lebanese and U.S. inflation rates, $e_{t}$ is the LL/US\$ exchange rate, and $u_{t}$ is an error term. All variables are in logarithms. 
Chart 16. Lebanon and Selected Other Countries: Real Effective Exchange Rates $(1980=100)$

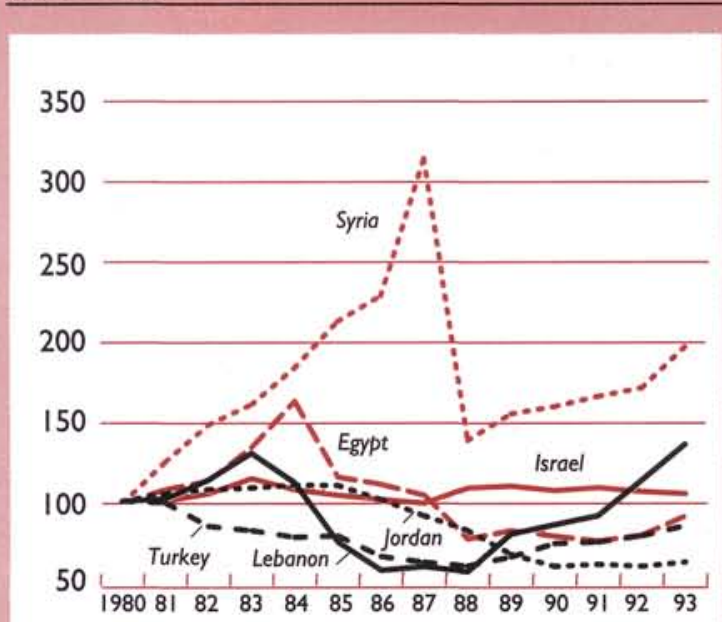

Source: International Monetary Fund, Information Notice System.

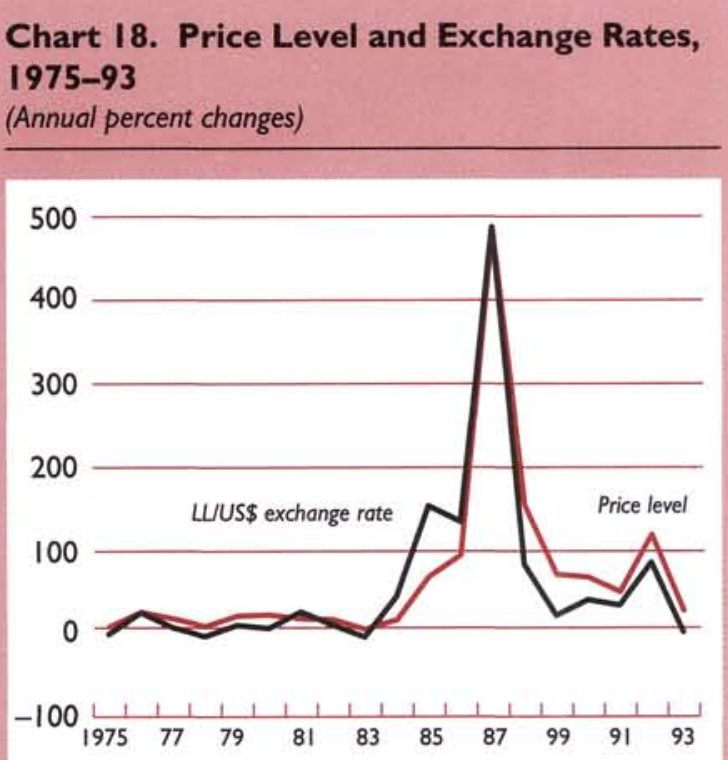

Sources: Bank of Lebanon; and International Monetary Fund, International Financial Statistics.

\section{Chart 17. Price Level and Exchange Rates, 1951-80 \\ (Annual percent changes)}

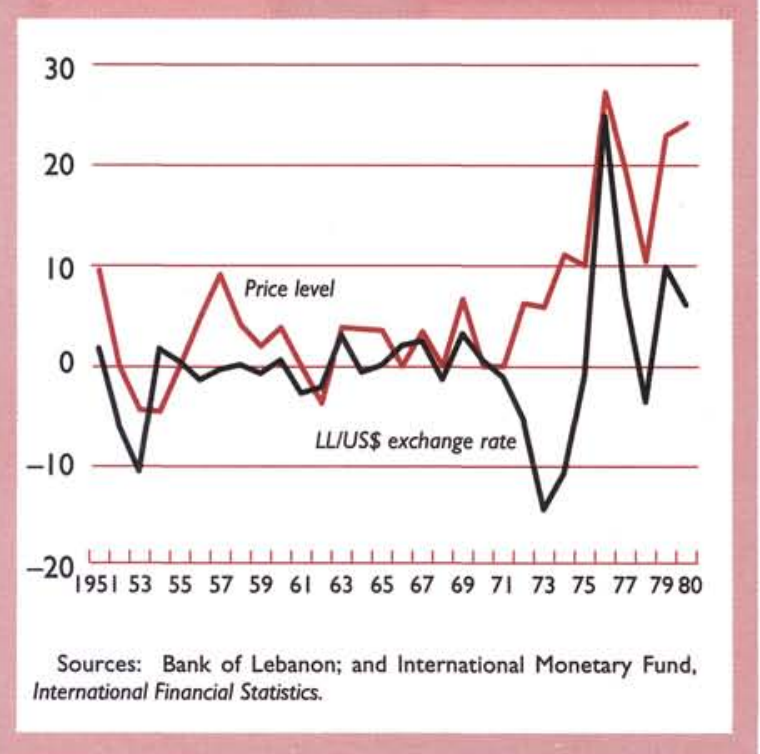

This equation was estimated for the periods before (1951-74) and after (1975-1993) the start of the civil war (Table 13). The results indicate that the relationship between the Lebanese-U.S. inflation differential and exchange rate movements was positive but not statistically significant before the civil war but has been both positive and strongly significant since 1975 . The relationship also proved to be positive and significant for the entire period of 1951-93.

For a more rigorous approach, annual data were used to examine the long-term relationship between exchange rate movements and inflation during 1951-93, by searching for possible changes in the relationship between exchange rate movements and inflation. ${ }^{61}$ Before the Johansen cointegration test can be applied, it must be determined whether the CPI and the LL/US\$ exchange rate series are nonstationary. After establishing that the annual period average series for the Lebanese CPI and the LL/US\$ exchange rate were nonstationary by the Dickey-Fuller and the augmented DickeyFuller tests (Table 14), 62 the Johansen method was used to examine the existence of a long-term relationship between inflation and changes in the exchange rate. ${ }^{63}$

\footnotetext{
${ }^{61}$ See Johansen (1988), and Johansen and Juselius (1990) for details of the Johansen test. The Johansen cointegration test was used here instead of the Phillips-Ouliaris test because this section has been largely confined to examining the correlation between inflation and exchange rate movements, rather than testing a specific, singleequation econometric model as was done for the money demand function in Section V.

${ }^{62}$ See Dickey and Fuller $(1979,1981)$. Dickey-Fuller tests for stationarity are used in this section as they are univariate versions of the Johansen procedure.

${ }^{63}$ The cointegration test was applied using alternative lag lengths in the vector autoregression (VAR).
} 


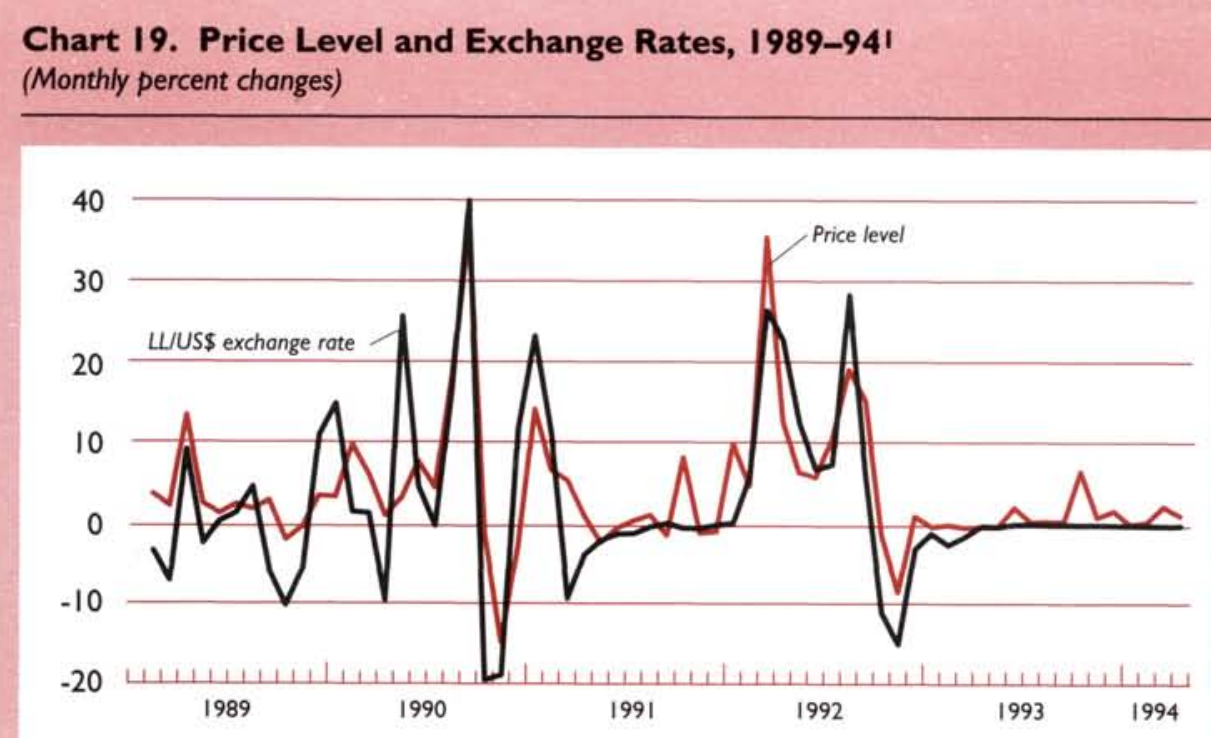

Sources: Bank of Lebanon; and International Monetary Fund, International Financial Stotistics,

ICovers January 1989-March 1994; monthly CPI data for Lebanon were not available prior to 1989.

The test results for 1951-74 indicated that there was no cointegration between these variables, which may be due to the fact that appreciations in the exchange rate are not passed through to prices as fully as depreciations. The appreciation of the exchange rate during

\section{Table 13. Regressions of the Differential Between Lebanese and U.S. Inflation Rates on Changes in the LL/US\$ Exchange RateI}

\begin{tabular}{lccc}
\hline & \multicolumn{3}{c}{ Time Period } \\
\cline { 2 - 4 } $\begin{array}{l}\text { Independent } \\
\text { Variable }\end{array}$ & $\begin{array}{c}\text { Overall } \\
\text { sample } \\
1951-93\end{array}$ & $\begin{array}{c}\text { Before } \\
\text { civil war } \\
1951-74\end{array}$ & $\begin{array}{c}\text { Since } \\
\text { civil war } \\
1975-93\end{array}$ \\
\hline Intercept & 0.05 & 0.00 & 0.09 \\
$\begin{array}{l}\text { Change in LLUS\$ } \\
\text { exchange rate }\end{array}$ & $\begin{array}{c}0.82 \\
(15.47)\end{array}$ & $\begin{array}{c}0.15 \\
(1.00)\end{array}$ & $\begin{array}{c}0.83 \\
(10.27)\end{array}$ \\
$\begin{array}{l}\text { Adjusted } R^{2} \\
\text { DW statistic }\end{array}$ & 0.93 & 0.01 & 0.90 \\
\hline
\end{tabular}

Source: IMF staff calculations.

IAll equations were estimated using annual CPI data. The estimation method was the exact maximum likelihood method with an $A R(I)$ error specification. The numbers in parentheses are t-statistics.
1951-74 may partly explain the lack of cointegration between exchange rate movements and inflation during this period. However, when applied to the period 1975-93, the data pointed to the existence of a cointegrated relationship between inflation and exchange rate movements at the 5 percent level of significance (Table 15). The results indicated a sizable and positive relationship between exchange rate movements and inflation since the outbreak of the civil war. The absence of cointegration before 1975 and its presence thereafter indicate a closer relationship between

Table 14. Dickey-Fuller Unit Root Tests, $1951-93$

\begin{tabular}{lrr} 
& \multicolumn{2}{c}{ Variable $^{2}$} \\
\cline { 2 - 3 } Sest & $\mathrm{e}$ & $\mathrm{P}$ \\
\hline Statistic & & 1.55 \\
ADF(1) & -0.94 & -0.33 \\
ADF(2) & -1.01 & -0.36 \\
ADF(3) & -0.68 & -0.13
\end{tabular}

Source: IMF staff calculations.

IDF and ADF are, respectively, the Dickey-Fuller and the augmented Dickey-Fuller test statistics for testing the null hypothesis of stationarity. The numbers in parentheses are lag lengths. The critical value for the 5 percent level of significance is -3.52 . $z_{e}=\log$ (LUUSS exchange rate); $p=\log (\mathrm{CPI})$. 


\section{Table 15. Johansen Cointegration Test, 1975-931}

Cointegration likelihood ratio test based on maximal eigenvalue of the stochastic matrix

Hypothesis ${ }^{2}$

\begin{tabular}{lccc} 
Null & Alternative & Test Statistic & Critical Value $^{3}$ \\
\hline$r=0$ & $r=1$ & 25.52 & 14.07 \\
$r \leq 1$ & $r=2$ & 0.45 & 3.76 \\
\hline
\end{tabular}

Cointegration likelihood ratio test based on the trace of the stochastic matrix

\begin{tabular}{lccc}
\multicolumn{2}{c}{ Hypothesis $^{2}$} & & \\
Null & Alternative & Test Statistic & Critical Value \\
\hline$r=0$ & $r \geq 0$ & 25.97 & 15.41 \\
$r \leq 1$ & $r=2$ & 0.45 & 3.76 \\
\hline
\end{tabular}

Estimated cointegration vector (coefficients normalized on $p)^{4}$

$\begin{array}{lr}p & -1.00 \\ e & 1.21\end{array}$

\section{Source: IMF staff calculations}

ISample: 1975-93; maximum lag of one year in VAR.

${ }^{2} r$ represents the number of cointegrating vectors.

${ }^{3}$ Critical values are for the 5 percent level of significance.

${ }^{4} e=\log$ (LLUS\$ exchange rate); $p=\log (C P I)$.

exchange rate movements and inflation since the start of the civil war. These results, however, should be interpreted cautiously in view of the small size of the sample used and the structural changes (a significant increase in the mean and trend of the CPI and exchange rate data) in the time series for inflation and the exchange rate.

Subsequently, the possibility of a change in the long-term relationship between inflation and exchange rate movements following the stabilization measures after October 1992 was examined using monthly data. For this purpose, the Johansen procedure was used to test for the existence of a cointegrated relationship between inflation and exchange rate movements for the period starting in January 1989. To test the stationarity of the CPI and the LL/US\$ exchange rate series, Dickey-Fuller and augmented Dickey-Fuller tests were again conducted. ${ }^{64}$ The results of these tests indicated that the time series

\footnotetext{
${ }^{64}$ However, the results tended to be mixed, as the null hypothesis of a unit root was rejected for both the exchange rate and the CPI for lag lengths of seven, eight, and nine months, which might be due to the parameter instability of the Dickey-Fuller test, or to the small size of the sample used.
}

Table 16. Dickey-Fuller Unit Root Tests, 1989-92।

\begin{tabular}{|c|c|c|c|}
\hline \multirow{2}{*}{$\begin{array}{l}\text { Test } \\
\text { Statistic }\end{array}$} & \multicolumn{2}{|c|}{ Variable ${ }^{3}$} & \multirow{2}{*}{$\begin{array}{l}\text { Critical } \\
\text { Value } 4\end{array}$} \\
\hline & e & $p$ & \\
\hline DF & -2.37 & -1.78 & -3.51 \\
\hline$A D F(I)$ & -3.00 & -2.63 & -3.51 \\
\hline$A D F(2)$ & -1.94 & -1.74 & -3.51 \\
\hline$A D F(3)$ & -2.28 & -1.84 & -3.51 \\
\hline ADF(4) & -2.89 & -1.94 & -3.52 \\
\hline$A D F(5)$ & -2.82 & -2.61 & -3.52 \\
\hline$A D F(6)$ & -3.44 & -3.09 & -3.52 \\
\hline$A D F(7)$ & -3.93 & -3.75 & -3.52 \\
\hline $\mathrm{ADF}(8)$ & -4.24 & -3.41 & -3.53 \\
\hline $\mathrm{ADF}(9)$ & -4.48 & -3.96 & -3.53 \\
\hline$A D F(10)$ & -3.09 & -3.35 & -3.53 \\
\hline$A D F(I I)$ & -2.87 & -3.03 & -3.54 \\
\hline $\operatorname{ADF}(12)$ & -2.08 & -2.65 & -3.54 \\
\hline
\end{tabular}

Source: IMF staff calculations.

ISample: January 1989-December 1992.

${ }^{2} \mathrm{DF}$ and $A D F$ are, respectively, the Dickey-Fuller and the augmented Dickey-Fuller test statistics for testing the null hypothesis of stationarity. The numbers in parentheses are lag lengths.

${ }^{3} e=\log$ (LUUS\$ exchange rate); $p=\log (\mathrm{CPI})$.

${ }^{4}$ Critical values are for the 5 percent level of significance.

for the CPI and the exchange rate were again nonstationary (Table 16). ${ }^{65}$

The cointegration test was conducted for the period January 1989-December 1992, and the existence of a long-term relationship between inflation and exchange rate movements could not be rejected (Table 17). ${ }^{66}$ The evidence presented suggests the existence of a close, long-run relationship between inflation and exchange rate movements in Lebanon from January 1989 until the end of 1992. Since the initiation of the stabilization program, the nominal exchange rate has gradually appreciated, but the earlier close relationship between inflation and exchange rate movements has not been present. This could reflect the fact that there had been little exchange rate volatility during this period and that appreciations in the exchange rate are not passed through to prices as fully as depreciations.

\footnotetext{
${ }^{65}$ Initially, unit root tests were conducted for the entire period January 1989-March 1994. Although the null hypothesis of a unit root in the exchange rate and CPI series could not be rejected, a closer inspection indicated that there was a structural break in these time series after the start of the stabilization program of 1992 . Over the period January 1993-March 1994, the exchange rate and CPI series were in fact stationary. Consequently, the results of the unit root tests are reported only through the end of 1992, and the cointegration tests are limited to the period January 1989-December 1992.

${ }^{66}$ The existence of cointegration over January 1989-December 1992 was also verified using the two-step method of Engle and Granger (1987).
} 


\section{Table 17. Johansen Cointegration Test, 1989-92'}

Cointegration likelihood ratio test based on maximal eigenvalue of the stochastic matrix

\begin{tabular}{cccc}
\multicolumn{2}{c}{ Hypothesis $^{2}$} & & \\
Null & Alternative & Test Statistic & Critical Value \\
\hline$r=0$ & $r=1$ & 19.46 & 14.06 \\
$r \leq 1$ & $r=2$ & 0.37 & 3.76 \\
\hline
\end{tabular}

Cointegration likelihood ratio test based on the trace of the stochastic matrix

Hypothesis ${ }^{2}$

\begin{tabular}{lccc} 
Null & Alternative & Test Statistic & Critical Value $^{3}$ \\
\hline$r=0$ & $r \geq 0$ & 19.82 & 15.41 \\
$r \leq 1$ & $r=2$ & 0.37 & 3.76 \\
\hline
\end{tabular}

Estimated cointegration vector (coefficients normalized on $p)^{4}$

$\begin{array}{lr}p & -1.00 \\ \text { e } & 1.41\end{array}$

\section{Source: IMF staff calculations.}

ISample: January 1989-December 1992, maximum lag of six months in VAR.

${ }^{2} r$ represents the number of cointegrating vectors.

${ }^{3}$ Critical values are for the 5 percent level of significance.

${ }^{4} e=\log$ (LUUSS exchange rate); $p=\log (\mathrm{CPI})$.

\section{Short-Term Dynamics of Inflation and the Exchange Rate and the Two-Way Relationship Between Them}

Although the above analysis was not intended to be a comprehensive analysis of the dynamics or determinants of inflation in Lebanon, it provides some evidence with regard to the close relationship between Lebanese inflation and exchange rate movements. Yet this does not imply a one-way influence from the exchange rate to prices. To examine the possibility of feedback from inflation to exchange rate movements, a number of error-correction equations were estimated using monthly data for January 1989-December 1992. The existence of a long-run relationship (cointegration) between prices and the exchange rate, as shown above, indicates that the short-term relationship among these variables can be captured through an error-correction representation. For this purpose, the two-step method of Engle and Granger was used. The estimated error-correction equation was of the following form:

$$
\Delta p_{t}=\beta_{0}+\beta_{1} \Delta e_{t}+\beta_{2} E C_{t-1}+\varepsilon_{t},
$$

where the error-correction term $E C_{t-1}$ represents the difference between the actual value of the CPI and the value predicted for the previous period from the cointegration relationship, and $\varepsilon_{t}$ is the error term. ${ }^{67}$ All variables are in natural logarithms. Estimation of the above equation for the period January 1989-December 1992 by OLS yielded the following results:

$$
\begin{aligned}
\Delta p_{t}= & 0.03+0.61 \Delta e_{t}-0.18 E C_{t-1} \\
& (4.05) \quad(9.59) \quad(-3.32)
\end{aligned}
$$

$$
\begin{aligned}
\text { Adjusted } \mathrm{R}^{2} & =0.66, \mathrm{DW} \text { statistic } \\
& =1.79, \text { standard error }=0.05 .
\end{aligned}
$$

The numbers in parentheses are t-statistics. The results point to a significant impact from exchange rate movements on the rate of inflation in the same month. Moreover, the negative coefficient for $E C_{t-1}$ indicates that departures of the inflation rate in any one period from the magnitude implied by the long-term relationship between the price level and the exchange rate will be corrected in the following period. Consequently, it is possible in the case of Lebanon that sharp movements in the exchange rate, which may be due to political events and capital flows, could trigger inflationary episodes.

The above results assumed that movements in the exchange rate were determined exogenously. To examine the possibility of weak exogeneity of the price level with respect to the exchange rate, the error-correction equation was re-estimated after switching the place of $\Delta p_{t}$ and $\Delta e_{t}{ }^{68} \mathrm{An}$ answer to this question is also important for the statistical interpretation of the above errorcorrection framework; unless the exchange rate is exogenous with respect to the price level, the coefficients of equation (1) would be biased and inefficient. A sufficient condition for weak exogeneity is that the coefficient $\delta_{2}$ in the following equation be equal to zero:

$$
\Delta e_{t}=\delta_{0}+\delta_{1} \Delta p_{t}+\delta_{2} E C_{t-1}+u_{t},
$$

where $u_{t}$ is the error term. Estimation of equation (2) yielded a statistically significant nonzero value for $\delta_{2}$ :

\footnotetext{
${ }^{67}$ Owing to a lack of degrees of freedom, only the most parsimonious error-correction equation is employed.

${ }^{68}$ As explained by McDermott and Wong (1990), for purposes of drawing inference and model formulation, the appropriate concept of exogeneity is weak exogeneity and not strict exogeneity (Granger non-causality). In addition, Toda and Phillips (1993) argue that Granger non-causality tests have serious limitations when applied to cointegrated systems. Hence, Granger non-causality tests were not applied in this section, and tests of weak exogeneity were applied to the error-correction model. For general discussions of exogeneity, especially in the context of cointegration, also see Banerjee and others (1993), and Ericsson (1991).
} 


$$
\Delta e_{t}=\underset{(-2.19)(9.59)}{-0.02+1.12 \Delta p_{t}+}+0.28 E C_{t-1}
$$

Adjusted $R^{2}=0.70$, DW statistic

$$
=1.84, \text { standard error }=0.07 \text {. }
$$

Thus, the possibility of feedback from the price level to the exchange rate could not be rejected, indicating that the exchange rate and the price level are determined simultaneously in Lebanon. 


\section{Appendix I Exchange and Trade System}

$\mathbf{T}$ his section summarizes Lebanon's exchange and trade system as of May 31, 1994.

\section{Exchange Arrangements}

The currency of Lebanon is the Lebanese pound. The authorities do not maintain margins in respect of foreign exchange transactions, and exchange rates are determined on the basis of demand and supply conditions in the exchange market. However, the authorities may announce buying or selling rates for certain currencies and intervene when necessary in order to maintain orderly conditions in the foreign exchange market. On May 31, 1994, the rate for the U.S. dollar was LL 1,684 per US\$1. There are no taxes or subsidies on purchases or sales of foreign exchange. The duties and taxes on imported goods and services invoiced or expressed in foreign currencies are calculated at a conversion rate of LL 800 per US $\$ 1$. Banks are allowed to engage in spot transactions in any currency but are prohibited from engaging in forward transactions exceeding LL 500,000 unless the transactions are related to foreign trade. Lebanon formally accepted the obligations of Article VIII, Sections 2, 3, and 4 of the Fund's Articles of Agreement effective July $1,1993$.

\section{Prescription of Currency}

No restrictions are imposed on exchange payments abroad or on receipts in Lebanon.

\section{Imports and Import Payments}

Imports of a few goods (mainly arms and ammunition, narcotics, and similar products) are either prohibited or reserved for the Government. All imports from Israel and South Africa are prohibited. Imports prohibited year-round include citrus fruits, apples, olives (excluding olives in cans weighing less than 2 kilograms), olive oil, and peanuts; imports prohibited dur- ing a specified period of the year include squash, eggplant, green beans, watermelons, peas, peaches, and apricots. Imports of certain other agricultural products and all seeds require a license. Import licenses are also required for certain finished goods, sanitary ceramic wares, insulated electric and telephone wires, and copper cables. All other commodities may be imported without a license. Foreign exchange to pay for imports may be obtained freely.

Before issuing letters of credit, banks are obliged to ensure that importers possess a valid import license, if required. Importers must place with their banks a prior deposit in a local currency amount equivalent to 15 percent of the value of import letters of credit; the banks are not required to deposit such amounts with the Bank of Lebanon.

A municipality tax of 3.5 percent is levied on the value of all goods imported, except those originating in an Arab country. A stamp tax is levied on all imports, except gold and bank notes, at the rate of LL 3 per LL 1,000 of the value of goods. The tariff regime is based on the Brussels Tariff Nomenclature. Ad valorem duty rates on most products range from 18 percent to 90 percent and are applied on a mostfavored-nation basis, except for certain imports from member countries of the European Union (EU) and Arab countries, which are accorded a preferential rate. A few products are subject to a specific duty. A surcharge of 10 percent of the applicable import duty is levied on certain textiles and garments. Surcharges are also levied on motor vehicles, imitation jewelry, watches, and alcoholic beverages. The surcharge on motor vehicles is levied at the following rates: 35 percent on vehicles valued at LL 10 million or less and 60 percent on vehicles valued at more than LL 10 million. The rate of surcharge on watches and imitation jewelry is 7 percent. The following rates of surcharge apply to alcoholic beverages: beer, LL 140 per 100 liters; champagne, 60 percent of the value; wine and arak, 20 percent of the value; and whiskey, 30 percent of the value. An additional construction tax of 11 percent, a municipality tax, and an internal tax ranging from LL 2.5 to LL 9.5 a liter are also imposed on champagne, wine, liqueurs, and whiskey. A tax of 60 percent is imposed on other beverages. 


\section{Payments for Invisibles}

There are no restrictions on payments for invisibles. Foreign exchange may be obtained in the free market.

\section{Exports and Export Proceeds}

Exports of certain goods (mainly arms and ammunition, narcotics, and similar products) to any destination and all exports to Israel and South Africa are prohibited. Exports of wheat and wheat derivatives to any country and all exports to the Democratic People's Republic of Korea require a license. Foreign exchange receipts from exports may be retained, used, or sold in the free market.

\section{Proceeds from Invisibles}

Foreign exchange receipts from invisibles may be retained, used, or sold in the free market.

\section{Capital}

There are no limitations on capital payments or receipts. Foreign exchange may be obtained or sold in the free market. Banks are prohibited from extending to nonresidents loans in Lebanese pounds and loans secured by guarantees from nonresident banks unless the transactions are for commercial or investment purposes in Lebanon. Banks are prohibited from receiving deposits, and from opening accounts in Lebanese pounds, for nonresident banks and financial institutions. Bank credit in Lebanese pounds to residents for the purchase of foreign exchange for purposes other than foreign trade transactions is subject to a special reserve requirement; the required reserve amounts to 40 percent of Lebanese pound loans that give rise directly to foreign currency deposits, and 15 percent of foreign currency deposits directly arising from Lebanese pound loans to depositors. Banks are authorized to maintain long or short net foreign currency positions up to 5 percent of the total core capital. In addition to the above, banks are authorized to maintain short positions not exceeding 60 percent of the same core capital that is paid up in Lebanese pounds. The amounts of investments in foreign currencies in nonresident banks and financial institutions are not included in net foreign currency positions. Investments in nonresident banks and other foreign institutions are exempt from the net foreign currency positions. Under a "free zone" banking facility, the commercial banks are exempt from reserve requirements and fees for deposit insurance on nonresidents' foreign currency deposits. Also, nonresidents are exempt from the 10 percent tax on interest earnings from foreign currency deposits.

Under the National Investment Insurance Scheme, new foreign investments are insured against losses arising from noncivil risks, including war. Compensation is paid on losses that are more than 10 percent of the insured value.

\section{Gold}

Residents may freely hold gold in any form at home or abroad and may freely negotiate gold in any form with residents and nonresidents, at home or abroad. The importation and exportation of gold in any form are freely permitted and do not require a license but must be officially recorded. The importation, exportation, and domestic sale of foreign gold coins must be covered by a certificate, issued by the Office for the Protection of the Consumer, that indicates the gold content and weight. 


\section{Appendix II Statistical Tables}

Table AI. Selected Social, Economic, and Financial Indicators

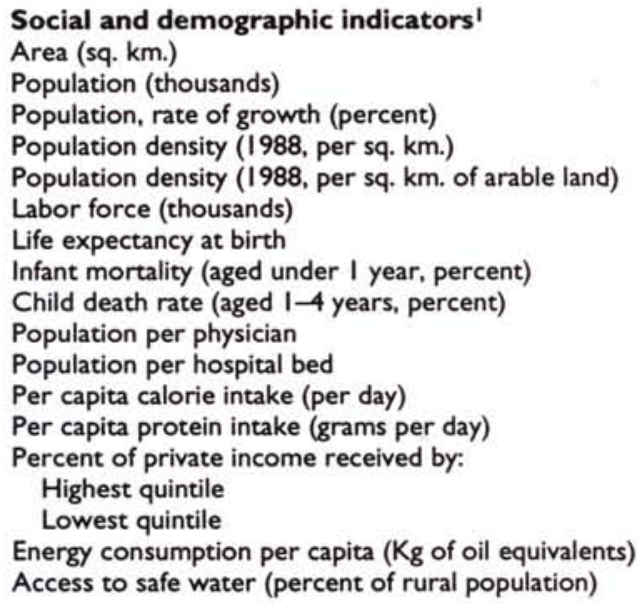

Population (thousands)

Population, rate of growth (percent)

Population density (1988, per sq. km.)

Population density (1988, per sq. km. of arable land)

Labor force (thousands)

Per capita calorie intake (per day)

Percent of private income received by:

Highest quintile

Access to safe water (percent of rural population)

\begin{tabular}{lllll}
1989 & 1990 & 1991 & 1992 & 1993 \\
\hline
\end{tabular}

Economic and financial indicators

National income and prices

Real GDP

Consumer prices (period average)

Consumer prices (end of period)

External sector

Exports (f.o.b.), U.S. dollar basis

Imports (f.o.b.). U.S. dollar basis

Nominal effective exchange rate (-depreciation)

Real effective exchange rate (- depreciation)

Central Government

\section{Revenue}

Expenditure

-42.2
72.2

89.0

$\begin{array}{rr}-23.0 & 2.5 \\ -6.0 & 13.9 \\ -14.2 & -33.4 \\ 41.7 & 7.3\end{array}$

\section{$-13.4$ \\ 68.8}

84.1

38.2

51.5

31.3

4.5

120.0

170.2

7.0

29.1
8.8

\section{9}

33.4
7.3

-1.2
45.4
-26.4

(Change in percent of broad money at the beginning of period, unless otherwise stated)

\footnotetext{
Money and credit

Net domestic credit, of which: Net claims on Government Claims on private sector
}

Money and quasi money

Velocity (GDP/broad money)

Interest rates

(end-of-period three-month treasury bills)

$\begin{array}{cccc}45.8 & 15.8 & 70.5 & 15.6 \\ 18.1 & 4.7 & 19.0 & 6.3 \\ 27.7 & 11.1 & 51.5 & 9.3 \\ 56.3 & 43.7 & 114.3 & 32.1^{3} \\ 0.512 & 0.746 & 0.800 & 0.834 \\ 18.8 & 15.0 & 13.0 & 17.2\end{array}$




\section{Table AI (concluded)}

\begin{tabular}{rrrrr}
1989 & \multicolumn{5}{c}{} & Est. \\
\cline { 3 - 5 } & 1990 & 1991 & 1992 & 1993 \\
142 & 146 & (In percent of GDP) & \\
20 & 20 & 145 & 135 & $\ldots$ \\
4.7 & 6.4 & 12.6 & 11.1 & 14.1 \\
39.1 & 39.4 & 28.9 & 23.4 & 22.52 \\
34.4 & 33.0 & 16.3 & 12.2 & 8.4 \\
17.8 & 17.5 & 11.0 & 10.8 & 9.1 \\
-83.2 & -90.8 & -84.2 & -68.0 & -56.0 \\
-28.9 & -47.6 & -65.9 & -55.1 & -45.3
\end{tabular}

\section{Economic and financial indicators}

Consumption 5

Investment ${ }^{5}$

Central Government

Revenue

Expenditure

Overall deficit

Exports (f.o.b.)

Imports (f.o.b.)

External current balance (excluding official transfers)

Central Government

Revenue

Overall deficit

External sector

Exports, f.o.b.

Workers' remittances

Imports, f.o.b.

Current account (excluding official transfers)

Overall balance (+ surplus)

Central bank liquid reserves (end of period)

(as months of current year's imports)

External debt outstanding (end of period) 6

External debt-service payments

Principal

Interest

Debt service (as percent of current receipts)

\section{Exchange rate}

Year average

End of period

GDP4
$-28.9$

12.1

87.9

16.2
83.8

(In percent of total expenditure)

$\begin{array}{llll}6.2 & 43.7 & 47.7 & 62.7\end{array}$

(In millions of U.S. dollars)

$\begin{array}{rr}484 & 496 \\ 480 & 280 \\ -2,263 & -2,578 \\ -785 & -1,351 \\ -309 & -431 \\ 907 & 623 \\ 4.8 & 2.9 \\ 332 & 332\end{array}$

490
180
$-3,748$
$-2,935$
1,074
1,237
4.0
332

601
200
$-3,770$
-3.053
54
1,448
4.6
273

$\ldots$

$\ldots$ 352

$\cdots$

... $\quad \ldots$

(Lebanese pounds per U.S. dollar)
497

505

695
842

928

879

1,713

1,838

1,741

(In billions of Lebanese pounds)
4,132

9,499

Sources: Ministry of Finance (MOF), Bank of Lebanon (BDL); IBRD; Council for Development and Reconstruction (CDR): and IMF staff estimates. 'Based on 1993 unless otherwise stated (IBRD Social Indicators of Development 1993).

2Includes capital (reconstruction) expenditures for CDR.

Includes SOLIDERE escrow deposits with BDL

${ }^{4} \mathrm{GDP}$ data are estimated on the basis of fragmentary information.

SIBRD data: "Country Strategy Note" dated July 12, 1993.

'Data currently being revised by the authorities. 


\section{APPENDIX II STATISTICAL TABLES}

Table A2. Selected Indicators of Sectoral Economic Activity

\begin{tabular}{llrrrrr} 
Indicator & Unit & 1989 & 1990 & 1991 & 1992 & 1993 \\
\hline Nominal GDP & Billions of Lebanese pounds & 1,350 & 1,973 & 4,132 & 9,499 & 13,122 \\
Real GDP & Percent change & -42.2 & -13.4 & 38.2 & 4.5 & 7.0 \\
$\begin{array}{l}\text { Consumer prices } \\
\text { Year average }\end{array}$ & Percent change & & & & & \\
$\quad$ End-year & Percent change & 72.2 & 68.8 & 51.5 & 120.0 & 29.1 \\
Agricultural exports & Millions of U.S. dollars & 89.0 & 84.1 & 31.3 & 170.2 & 8.8 \\
Industrial exports & Millions of U.S. dollars & $\ldots$ & 25.7 & 62.4 & 92.3 & 86.8 \\
Electricity production & Million kwh & $\ldots$ & 188.3 & 311.0 & 418.0 & 392.3 \\
Construction permits & Thousand sq m & 2,549 & 1,532 & 2,920 & 4,033 & 4,170 \\
Cement deliveries & Thousand metric tons & 1,971 & 2,211 & 6,134 & 10,745 & 15,053 \\
Port of Beirut & Number of ships & $\ldots$ & 1,269 & 1,690 & 2,127 & 3,045 \\
Beirut Airport & Thousands of passengers & 221 & 710 & 826 & 1,044 \\
\hline
\end{tabular}

Source: Lebanese authorities.

Table A3. Consumer Price Indices' (Average for 1988 $=100$ )

\begin{tabular}{|c|c|c|c|c|c|}
\hline & Index & $\begin{array}{l}\text { Annual Rate } \\
\text { of Change }{ }^{2}\end{array}$ & & Index & $\begin{array}{l}\text { Annual Rate } \\
\text { of Change }\end{array}$ \\
\hline & (Period average) & (In percent) & & (Period average) & (In percent) \\
\hline 1988 & 100.0 & 155.0 & 1993 (continued) & & \\
\hline 1989 & 172.2 & 72.2 & June & 1,229.7 & 36.9 \\
\hline 1990 & 290.7 & 68.8 & July & $1,231.0$ & 24.0 \\
\hline 1991 & 440.3 & 51.5 & August & $1,233.4$ & 4.3 \\
\hline 1992 & 968.6 & 120.0 & September & $1,235.9$ & -9.3 \\
\hline 1993 & $1,250.6$ & 29.1 & October & $1,315.0$ & -1.9 \\
\hline & & & November & $1,324.2$ & 8.1 \\
\hline 1993 & & & December & $1,344.1$ & 8.8 \\
\hline January & $1,228.8$ & 144.8 & & & \\
\hline February & $1,226.4$ & 133.6 & 1994 & & \\
\hline March & $1,219.0$ & 71.4 & January & $1,341.5$ & 9.2 \\
\hline April & $1,212.9$ & 51.6 & February & $1,342.7$ & 9.5 \\
\hline May & $1,206.8$ & 42.0 & March & $1,370.0$ & 12.4 \\
\hline
\end{tabular}

Source: Lebanese authorities.

IBased on an index for Beirut and suburbs prepared by the Consultation and Research Institute for the Trade Union Confederation.

2Annual data are averages of the 12-month period ending December, while monthly data represent changes with respect to the same month in the previous year. 
Table A4. Summary of Central Government Operations'

\begin{tabular}{|c|c|c|c|c|c|c|}
\hline & & & & & Budget & Outturn \\
\hline & 1989 & 1990 & 1991 & 1992 & 1993 & 1993 \\
\hline & \multicolumn{6}{|c|}{ (In billions of Lebanese pounds) } \\
\hline Revenue & 64 & 126 & 522 & 1,059 & 1,701 & 1,855 \\
\hline Indirect taxes & 4 & 4 & 132 & 467 & 864 & 806 \\
\hline Customs duties & 2 & 2 & 98 & 323 & 700 & 662 \\
\hline Other & 2 & 2 & 34 & 144 & 164 & 144 \\
\hline Direct taxes & 15 & 37 & 90 & 46 & 285 & 172 \\
\hline Fees, dues, and charges & 8 & 15 & 79 & 93 & 150 & 179 \\
\hline Other & 38 & 71 & 222 & 453 & 403 & 697 \\
\hline Of which: Bank of Lebanon profits & 29 & 65 & 134 & 79 & 63 & 63 \\
\hline Expenditure 1 & 528 & 778 & 1,196 & 2,219 & 3,400 & 2,957 \\
\hline Current expenditures & 495 & 745 & 1,035 & 2,073 & 2,909 & 2,757 \\
\hline Wages and salaries & 97 & 210 & 370 & 660 & 750 & 640 \\
\hline Other current ${ }^{2}$ & 147 & 276 & 425 & 750 & 1,428 & 1,152 \\
\hline Interest payments & 152 & 214 & 206 & 519 & 731 & 784 \\
\hline Domestic & 152 & 204 & 204 & 454 & 731 & 754 \\
\hline Foreign & 1 & 10 & 2 & 65 & $\ldots$ & 30 \\
\hline Fuel subsidy ${ }^{3}$ & 99 & 46 & 35 & 145 & $\ldots$ & 181 \\
\hline Capital expenditures & 33 & 33 & 161 & 146 & 491 & 200 \\
\hline Of which: Foreign-financed & 一 & 一 & - & 一 & - & 52 \\
\hline Deficit & -464 & -652 & -674 & $-1,160$ & $-1,699$ & $-1,102$ \\
\hline Financing & 464 & 652 & 650 & 979 & 1,699 & 1,131 \\
\hline Foreign & -2 & - & - & -108 & $\ldots$ & 190 \\
\hline Grants & $\ldots$ & - & - & - & $\ldots$ & 52 \\
\hline Net borrowing & $\ldots$ & - & - & -108 & $\cdots$ & 138 \\
\hline Disbursements & $\ldots$ & - & - & - & $\ldots$ & 219 \\
\hline Amortization & $\ldots$ & - & - & -108 & $\ldots$ & -82 \\
\hline Domestic & 466 & 652 & 650 & 1,087 & 1,699 & 941 \\
\hline Banking system & 400 & 576 & 183 & 1,055 & $\ldots$ & 751 \\
\hline Bank of Lebanon & 120 & 446 & -424 & -668 & $\ldots$ & -119 \\
\hline Commercial banks & 279 & 130 & 607 & 1,722 & $\ldots$ & 870 \\
\hline Nonbank private & 67 & 76 & 467 & 32 & $\ldots$ & 190 \\
\hline Discrepancy 4 & 一 & - & -24 & -181 & - & 29 \\
\hline \multicolumn{7}{|l|}{ Memorandum items: } \\
\hline & \multicolumn{6}{|c|}{ (In percent of GDP) } \\
\hline Deficit & -34 & -33 & -16 & -12 & -13 & -8 \\
\hline Deficit excluding foreign-financed & & & & & & \\
\hline capital expenditures & -34 & -33 & -16 & -12 & $\ldots$ & -8 \\
\hline Revenue & 5 & 6 & 13 & 11 & 13 & 14 \\
\hline Expenditures & 39 & 39 & 29 & 23 & 26 & 23 \\
\hline Current balance & -32 & -31 & -12 & -11 & -9 & -7 \\
\hline \multirow[t]{2}{*}{ Domestic financing } & 35 & 33 & 16 & 11 & 13 & 7 \\
\hline & \multicolumn{6}{|c|}{ (In percent of expenditures) } \\
\hline Deficit & -88 & -84 & -56 & -52 & -50 & -37 \\
\hline Deficit excluding foreign-financed & & & & & & \\
\hline capital expenditures 5 & -88 & -84 & -56 & -52 & & -36 \\
\hline Revenue & 12 & 16 & 44 & 48 & 50 & 63 \\
\hline Domestic financing & 88 & 84 & 54 & 49 & 50 & 32 \\
\hline \multirow{2}{*}{\multicolumn{7}{|c|}{$\begin{array}{l}\text { Sources: Ministry of Finance; Bank of Lebanon; and IMF staff estimates. } \\
\text { IIncludes foreign and domestically financed CDR expenditure. }\end{array}$}} \\
\hline \multirow{2}{*}{\multicolumn{7}{|c|}{$\begin{array}{l}\text { Includes foreign and domestically financed } \\
2 \text { Includes advances and transfers. }\end{array}$}} \\
\hline & & & & & & \\
\hline \multicolumn{7}{|c|}{ 3Petroleum subsidy paid to Electricité du Liban. } \\
\hline \multicolumn{7}{|l|}{${ }^{4}$ Discrepancy between deficit and financing. } \\
\hline SIn percent of expenditures excluding forei & Asnit & & & & & \\
\hline
\end{tabular}


Table A5. Treasury Bills in Circulation (In millions of Lebanese pounds)

\begin{tabular}{|c|c|c|c|c|c|}
\hline Type of Bill & 1989 & 1990 & 1991 & 1992 & 1993 \\
\hline \multicolumn{6}{|l|}{ 3-month } \\
\hline Issue & 584,874 & 587,721 & 596,542 & $2,031,161$ & $2,525,425$ \\
\hline Reimbursement & 544,459 & 567,600 & 595,530 & $1,077,401$ & $3,051,324$ \\
\hline In circulation (end of period) & 149,004 & 169,125 & 170,136 & $1,123,896$ & 597,997 \\
\hline \multicolumn{6}{|l|}{ 6-month } \\
\hline Issue & 280,737 & 357,907 & 470,675 & 863,348 & $1,542,817$ \\
\hline Reimbursement & 201,243 & 297,417 & 454,373 & 469,856 & $1,294,939$ \\
\hline In circulation (end of period) & 159,027 & 219,517 & 235,820 & 629,312 & 877,190 \\
\hline \multicolumn{6}{|l|}{ 12-month } \\
\hline Issue & 457,766 & 607,789 & $1,480,330$ & $1,|84,58|$ & $1,769,311$ \\
\hline Reimbursement & 225,803 & 457,769 & 607,787 & $1,487,299$ & $1,177,610$ \\
\hline In circulation (end of period) & 457.767 & 607,787 & $1,480,330$ & $1,177,612$ & $1,769,313$ \\
\hline \multicolumn{6}{|l|}{ 18-month } \\
\hline Issue & - & - & 57,023 & 164,845 & - \\
\hline Reimbursement & - & - & - & - & 95,677 \\
\hline In circulation (end of period) & - & - & 57,023 & 221,868 & $126,19 \mid$ \\
\hline \multicolumn{6}{|l|}{ 24-month } \\
\hline Issue & - & - & 344,378 & $1,161,890$ & $1,366,918$ \\
\hline Reimbursement & - & - & - & - & 350,640 \\
\hline In circulation (end of period) & - & - & 344,378 & $1,506,268$ & $2,522,546$ \\
\hline \multicolumn{6}{|l|}{ Special bills' } \\
\hline Issue & 35,959 & 47,991 & 75,926 & 120,025 & 238,825 \\
\hline Reimbursement & 27,251 & 42,025 & 57,018 & 70,073 & 203,124 \\
\hline In circulation (end of period) & 20,618 & 26,584 & 45,492 & 95,444 & 131,145 \\
\hline \multicolumn{6}{|l|}{ Total bills } \\
\hline Issuance & $1,359,336$ & $1,601,448$ & $3,024,874$ & $5,525,850$ & $7,443,296$ \\
\hline Reimbursements & 998,756 & $|, 364,8| 1$ & $1,714,708$ & $3,104,629$ & $6,173,314$ \\
\hline In circulation (end of period) & 786,416 & 1.023 .013 & $2,333,179$ & $4,754,400$ & $6.024,382$ \\
\hline
\end{tabular}

Source: Bank of Lebanon.

ISpecial bills that can be part of the reserve requirement. Commercial banks must hold 3 percent of deposits as reserves in the form of these bills, which earn a fixed interest rate of 6 percent a year. 
Table A6. Bank of Lebanon Balance Sheet'

(End-ofperiod stocks; in billions of Lebanese pounds)

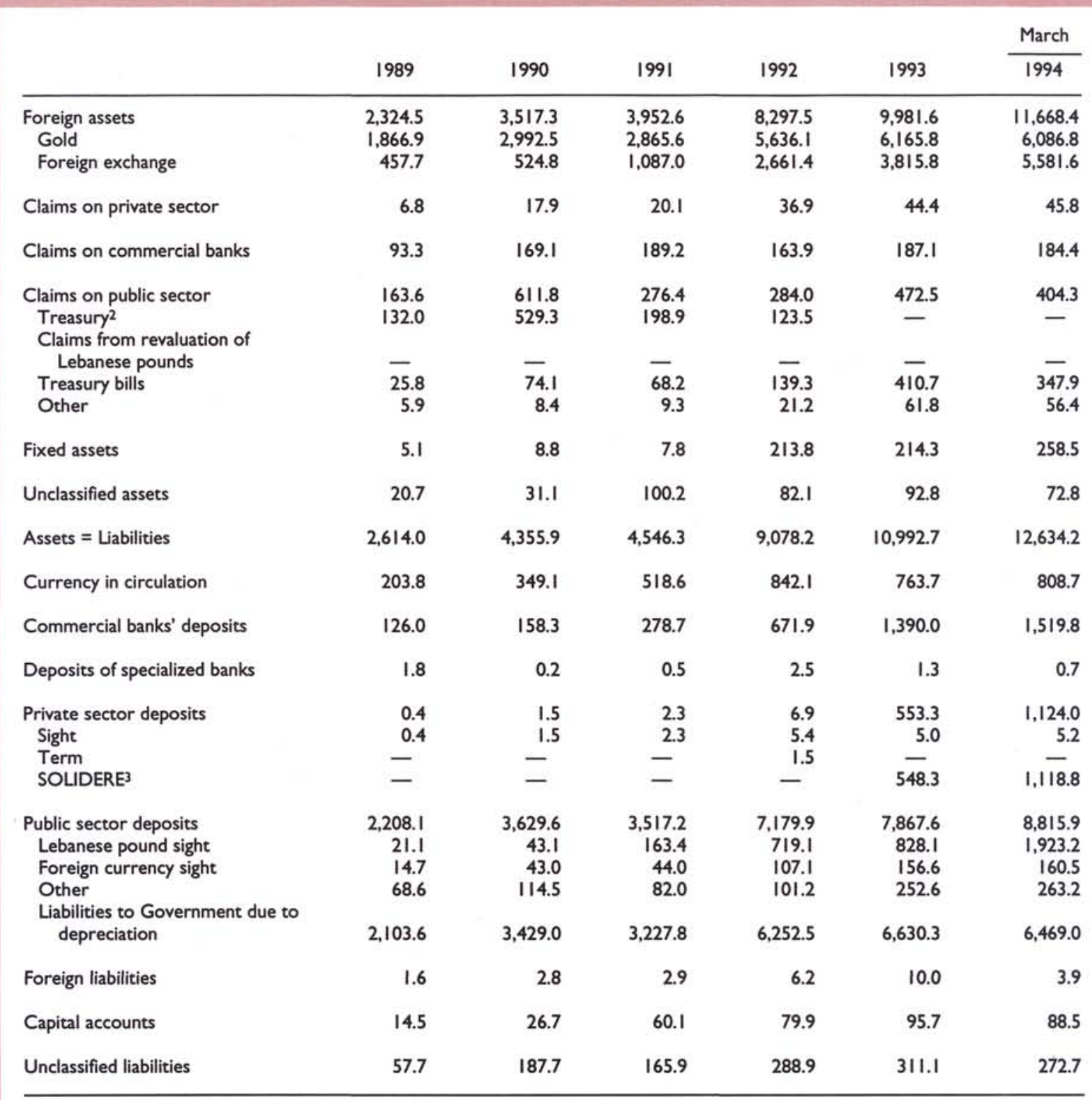

Source: Bank of Lebanon.

'Bank of Lebanon format.

2Treasury debit and credit accounts were unified in September 1993.

3SOLIDERE accounts were opened in November 1993. Also includes other foreign currency deposits. 
Table A7. Commercial Banks' Balance Sheet'

(End-of-period stocks; in billions of Lebanese pounds)

\begin{tabular}{|c|c|c|c|c|c|c|}
\hline & & & & & & March \\
\hline & 1989 & 1990 & 1991 & 1992 & 1993 & 1994 \\
\hline Reserves & 130.9 & 178.0 & 282.5 & 669.2 & $1,434.9$ & $1,518.4$ \\
\hline Currency & 11.4 & 16.1 & 33.9 & 44.1 & 49.0 & 46.2 \\
\hline Deposits with Bank of Lebanon & 119.5 & 161.9 & 248.6 & 625.1 & $1,385.9$ & $1,472.2$ \\
\hline Claims on private sector & 878.1 & $1,548.3$ & $1,971.1$ & $4,804.0$ & $5,897.9$ & $6,741.4$ \\
\hline Lebanese pounds & 175.1 & 258.3 & 343.4 & 436.1 & 631.5 & 682.9 \\
\hline Foreign currency & 703.0 & $1,290.0$ & $1,627.7$ & $4,367.9$ & $5,266.4$ & $6,058.5$ \\
\hline Claims on public sector & 558.3 & 688.4 & $1,309.4$ & $3,098.3$ & $4,013.3$ & $5,266.6$ \\
\hline Treasury bills & 557.0 & 681.1 & $1,302.4$ & $3,082.8$ & $4,010.0$ & $5,262.4$ \\
\hline Other & 1.3 & 7.3 & 7.0 & 15.5 & 3.3 & 4.2 \\
\hline Foreign assets & I,458.2 & $2,374.5$ & $3,061.2$ & $5,824.8$ & $7,040.7$ & $5,469.4$ \\
\hline Fixed assets & 30.9 & 57.8 & 90.0 & 144.3 & 258.7 & 267.3 \\
\hline Unclassified assets & 67.7 & 88.5 & 83.6 & 93.7 & 163.4 & 242.8 \\
\hline Assets $=$ Liabilities & $3,124.1$ & $4,935.5$ & $6,797.8$ & $14,634.3$ & $18,808.9$ & $19,505.9$ \\
\hline Private sector deposits & $2,270.5$ & $3,518.8$ & $5,051.0$ & $11,062.1$ & $14,409.2$ & $14,854.0$ \\
\hline Lebanese pounds & 750.8 & 934.2 & $1,663.6$ & $3,587.2$ & $4,587.8$ & $5,911.0$ \\
\hline Sight & 92.5 & 115.3 & 202.0 & 393.5 & 422.4 & 435.4 \\
\hline Term & 658.2 & 818.9 & $1,461.6$ & $3,193.7$ & $4,165.4$ & $5,475.6$ \\
\hline Foreign currency & $1,519.8$ & $2,584.6$ & $3,387.4$ & $7,474.9$ & $9,821.4$ & $8,943.0$ \\
\hline Sight & 189.6 & 328.3 & 506.6 & $1,238.3$ & $1,748.0$ & $1,541.3$ \\
\hline Term & $1,330.2$ & $2,256.3$ & $2,880.8$ & $6,236.6$ & $8,073.4$ & $7,401.7$ \\
\hline Public sector deposits & 11.3 & 26.1 & 40.0 & 106.5 & 151.7 & 233.1 \\
\hline Liabilities to nonresident banks & 277.7 & 437.7 & 373.8 & 599.0 & 658.3 & 560.7 \\
\hline Deposits of nonresidents & 170.5 & 276.1 & 468.1 & $1,099.8$ & $1,392.7$ & $1,424.5$ \\
\hline Of which: In Lebanese pounds & 43.5 & 64.2 & 86.4 & 133.5 & 157.3 & 162.3 \\
\hline Capital accounts & 23.7 & 103.9 & 147.9 & 263.5 & 444.1 & 560.7 \\
\hline Unclassified liabilities & 370.4 & 572.9 & 717.0 & $1,503.5$ & $1,753.0$ & $1,872.9$ \\
\hline
\end{tabular}

Source: Bank of Lebanon.

IBank of Lebanon format. 
Table A8. Monetary Survey

(End-ofperiod stocks; in billions of Lebanese pounds)

\begin{tabular}{|c|c|c|c|c|c|c|}
\hline & & & & & & March \\
\hline & 1989 & 1990 & 1991 & 1992 & 1993 & 1994 \\
\hline Total liquidity & $2,465.2$ & $3,853.4$ & $5,538.5$ & $11,869.5$ & $15,678.5$ & $16,741.2$ \\
\hline Money & 287.2 & 449.9 & 689.5 & $1,199.4$ & $1,143.4$ & $1,203.8$ \\
\hline Currency & 192.4 & 333.0 & 484.7 & 798.0 & 714.7 & 762.5 \\
\hline Demand deposits in domestic currency & 94.8 & 117.0 & 204.8 & 401.4 & 428.7 & 441.3 \\
\hline Quasi money & $2,178.0$ & $3,403.5$ & $4,849.0$ & $10,670.1$ & $14,535.1$ & $15,537.4$ \\
\hline Domestic currency time and savings deposits & 658.2 & 818.9 & 1.461 .6 & $3,195.2$ & $4,165.4$ & $5,475.6$ \\
\hline Foreign currency deposits 1 & $1,519.8$ & $2,584.6$ & $3,387.4$ & $7,474.9$ & $10,369.7$ & $10,061.8$ \\
\hline Net foreign assets & $3,349.8$ & $5,206.0$ & $6,203.1$ & $12,488.8$ & $15,030.2$ & $15,219.2$ \\
\hline Domestic claims & $1,480.1$ & $2,608.8$ & $3,213.5$ & $7,117.8$ & $8,970.2$ & $9,807.6$ \\
\hline Net claims on public sector & 595.2 & $1,042.6$ & $1,222.3$ & $2,276.9$ & $3,027.9$ & $3,020.4$ \\
\hline Lebanese pounds & 678.5 & $1,200.1$ & $1,348.3$ & $2,485.2$ & $3,437.1$ & $3,444.1$ \\
\hline Foreign currency & -83.4 & -157.5 & -126.0 & -208.3 & -409.2 & -423.7 \\
\hline Claims on private sector & 884.9 & 1,566.2 & $1,991.2$ & $4,840.9$ & $5,942.3$ & $6,787.2$ \\
\hline Lebanese pounds & 181.9 & 276.2 & 363.5 & 473.0 & 675.9 & 728.7 \\
\hline Foreign currency & 703.0 & $1,290.0$ & $1,627.7$ & $4,367.9$ & $5,266.4$ & $6,058.5$ \\
\hline Other items (net) & $-2,364.7$ & $-3,961.4$ & $-3,878.1$ & $-7,737.1$ & $-8,321.9$ & $-8,285.6$ \\
\hline Of which: Exchange revaluation & & & & & & \\
\hline account of Bank of Lebanon & $-2,109.5$ & $-3,429.0$ & $-3,227.8$ & $-6,252.5$ & $-6,630.3$ & $-6,469.0$ \\
\hline Memorandum items: & & & & & & \\
\hline $\begin{array}{l}\text { Total liquidity (percent change) }{ }^{2} \\
\text { Lebanese pound component of liquidity }\end{array}$ & 13.4 & 56.3 & 43.7 & 114.3 & 32.1 & 41.2 \\
\hline (as percent of total liquidity) & 38.3 & 32.9 & 38.8 & 37.0 & 33.9 & 39.9 \\
\hline Change in net credit to the public sector & & & & & & \\
\hline (as percent of total liquidity at beginning of period) & 17.6 & 18.1 & 4.7 & 19.0 & 6.3 & -0.1 \\
\hline Change in credit to the private sector & & & & & & \\
\hline $\begin{array}{l}\text { (as percent of total liquidity at beginning of period) } \\
\text { Foreign currency component of liquidity }\end{array}$ & 6.7 & 27.6 & II.I & 51.5 & 9.3 & 5.4 \\
\hline (in millions of U.S. dollars) & 3,009 & 3,070 & 3,854 & 4,067 & 6,061 & 5,938 \\
\hline
\end{tabular}

Source: Bank of Lebanon.

ISOLIDERE deposits are included as foreign currency deposits.

2For March 1994, the data represent percentage changes from the stock at end of March the previous year.

Table A9. Factors Affecting Lebanese Pound Component of Domestic Liquidity

(In percent of Lebanese pound component of liquidity at beginning of period) 
Table A 10. Distribution of Residents' Monetary Assets (In percent of total liquidity)

\begin{tabular}{|c|c|c|c|c|c|c|}
\hline & \multirow[b]{2}{*}{1989} & \multirow[b]{2}{*}{1990} & \multirow[b]{2}{*}{1991} & \multirow[b]{2}{*}{1992} & \multirow[b]{2}{*}{1993} & \multirow{2}{*}{$\frac{\text { March }}{1994}$} \\
\hline & & & & & & \\
\hline Total liquidity & 100.0 & 100.0 & 100.0 & 100.0 & 100.0 & 100.0 \\
\hline Money & 11.6 & 11.7 & 12.4 & 10.1 & 7.3 & 7.2 \\
\hline Currency & 7.8 & 8.6 & 8.8 & 6.7 & 4.6 & 4.6 \\
\hline Demand deposits in Lebanese pounds & 3.8 & 3.0 & 3.7 & 3.4 & 2.7 & 2.6 \\
\hline Quasi money & 88.4 & 88.3 & 87.6 & 89.9 & 92.7 & 92.8 \\
\hline Domestic currency time and savings deposits & 26.7 & 21.3 & 26.4 & 26.9 & 26.6 & 32.7 \\
\hline Foreign currency deposits & 61.6 & 67.1 & 61.2 & 63.0 & 66.1 & 60.1 \\
\hline Foreign currency demand deposits & 7.7 & 8.5 & 9.1 & 10.4 & 11.1 & 9.2 \\
\hline Foreign currency time and savings deposits & 54.0 & 58.6 & 52.0 & 52.5 & 55.0 & 50.9 \\
\hline
\end{tabular}

Source: Bank of Lebanon.

Table Al I. Commercial Banks' Claims on Private Sector Classified by Economic Activity'

\begin{tabular}{|c|c|c|c|c|c|c|c|}
\hline & 1989 & 1990 & 1991 & 1992 & 1993 & 1989 & 1993 \\
\hline & \multicolumn{5}{|c|}{ (In billions of Lebanese pounds) } & \multicolumn{2}{|c|}{ (In percent of total) } \\
\hline Agriculture & 11.6 & 16.7 & 28.2 & 60.5 & 74.9 & 1.3 & 1.3 \\
\hline Industry & 97.5 & 154.8 & 182.7 & 418.2 & 530.0 & 11.1 & 9.0 \\
\hline Construction & 72.3 & 134.1 & 186.3 & 398.0 & 533.4 & 8.2 & 9.0 \\
\hline $\begin{array}{l}\text { Trade and services } \\
\text { Of which: }\end{array}$ & 431.4 & 799.4 & $1,038.8$ & $2,553.8$ & $3,164.7$ & 49.2 & 53.7 \\
\hline $\begin{array}{l}\text { Foreign trade } \\
\text { Domestic trade }\end{array}$ & $\begin{array}{l}134.0 \\
215.0\end{array}$ & $\begin{array}{l}223.8 \\
428.5\end{array}$ & $\begin{array}{l}271.4 \\
604.6\end{array}$ & $\begin{array}{r}500.9 \\
1,533.7\end{array}$ & $\begin{array}{r}551.6 \\
1,992.2\end{array}$ & $\begin{array}{l}15.3 \\
24.5\end{array}$ & $\begin{array}{r}9.4 \\
33.8\end{array}$ \\
\hline Other services & 57.6 & 100.7 & 99.8 & 321.3 & 457.3 & 6.6 & 7.8 \\
\hline Consumer credit & 24.8 & 46.4 & 63.0 & 197.9 & 163.6 & 2.8 & 2.7 \\
\hline Financial institutions & 29.9 & 40.4 & 36.3 & 55.2 & 50.1 & 3.4 & 0.9 \\
\hline Other & 235.0 & 401.9 & 498.2 & $1,315.7$ & $1,541.4$ & 26.8 & 26.1 \\
\hline Total & 877.7 & $1,547.3$ & $1,970.5$ & $4,801.4$ & 5.894 .5 & 100.0 & 100.0 \\
\hline
\end{tabular}

Source: Bank of Lebanon.

'At end of period. 


\section{Table A 12. Discounts and Yields on Three-Month Treasury Bills (End of period; in percent a year)}

\begin{tabular}{|c|c|c|c|c|}
\hline & \multicolumn{2}{|c|}{ Primary Market } & \multicolumn{2}{|c|}{ Secondary Market } \\
\hline & Discount & Yield & Discount & Yield \\
\hline \multicolumn{5}{|l|}{1989} \\
\hline March & 18.00 & 18.84 & 18.00 & 18.84 \\
\hline June & 18.00 & 18.84 & 18.00 & 18.84 \\
\hline September & 18.00 & 18.84 & 18.00 & 18.84 \\
\hline December & 18.00 & 18.84 & 18.00 & 18.84 \\
\hline \multicolumn{5}{|l|}{1990} \\
\hline March & 18.00 & 18.84 & 18.00 & 18.84 \\
\hline June & 18.00 & 18.84 & 18.00 & 18.84 \\
\hline September & 18.00 & 18.84 & 18.00 & 18.84 \\
\hline December & 18.00 & 18.84 & 18.00 & 18.84 \\
\hline \multicolumn{5}{|l|}{1991} \\
\hline March & 19.00 & 19.94 & 19.00 & 19.94 \\
\hline June & 17.50 & 18.30 & 17.50 & 18.30 \\
\hline September & 16.00 & 16.61 & 16.00 & 16.61 \\
\hline December & 14.50 & 15.04 & 14.50 & 15.04 \\
\hline \multicolumn{5}{|l|}{1992} \\
\hline March & 22.50 & 23.84 & 22.50 & 23.84 \\
\hline June & 22.50 & 23.84 & 22.50 & 23.84 \\
\hline September & 31.50 & 34.18 & 33.50 & 36.55 \\
\hline December & 12.59 & 13.00 & 12.59 & 13.00 \\
\hline \multicolumn{5}{|l|}{1993} \\
\hline March & 19.96 & 21.01 & 19.96 & 21.01 \\
\hline June & 17.67 & 18.48 & 17.67 & 18.48 \\
\hline September & 17.28 & 18.06 & 17.28 & 18.06 \\
\hline December & 16.51 & 17.22 & 16.51 & 17.22 \\
\hline \multicolumn{5}{|l|}{1994} \\
\hline March & 15.69 & 16.33 & 15.69 & 16.33 \\
\hline
\end{tabular}

Source: Bank of Lebanon. 
Table A 13. Commercial Bank Interest Rates on Lebanese Pound Transactions, 1989-941 (In percent)

\begin{tabular}{|c|c|c|c|c|c|c|c|c|}
\hline & \multirow{3}{*}{$\begin{array}{l}\text { Lending Rates }{ }^{2} \\
\text { Discount } \\
\text { and loans }\end{array}$} & \multicolumn{4}{|c|}{ Deposit Rates ${ }^{2}$} & \multicolumn{3}{|c|}{ Interbank Rates on Call } \\
\hline & & \multirow{2}{*}{$\begin{array}{l}\text { Checking } \\
\text { and current } \\
\text { accounts }\end{array}$} & \multirow[b]{2}{*}{$\begin{array}{l}\text { Savings } \\
\text { at call }\end{array}$} & \multirow{2}{*}{$\begin{array}{c}\text { Term } \\
\text { savings } \\
\text { and deposits }\end{array}$} & \multirow[b]{2}{*}{$\begin{array}{c}\text { Average } \\
\text { rate }\end{array}$} & \multirow{2}{*}{$\begin{array}{l}\text { Lowest rate } \\
\text { during the } \\
\text { period }\end{array}$} & \multirow{2}{*}{$\begin{array}{l}\text { Highest rate } \\
\text { during the } \\
\text { period }\end{array}$} & \multirow{2}{*}{$\begin{array}{c}\text { End-of- } \\
\text { period } \\
\text { rate }\end{array}$} \\
\hline & & & & & & & & \\
\hline 1989 & 39.43 & 5.01 & 11.77 & 16.38 & 14.51 & 5.00 & 20.00 & 10.00 \\
\hline 1990 & 39.39 & 4.55 & 11.47 & 16.96 & 15.14 & 15.00 & 90.00 & 25.00 \\
\hline 1991 & 31.54 & 3.74 & 11.83 & 15.37 & 13.81 & 9.50 & 12.00 & 12.00 \\
\hline 1992 & 27.45 & 1.50 & 8.34 & 14.26 & 11.48 & 3.00 & 5.00 & 5.00 \\
\hline 1993 & 29.29 & 1.88 & 10.43 & 16.10 & 13.18 & 6.00 & 6.00 & 6.00 \\
\hline \multicolumn{9}{|l|}{1993} \\
\hline March & 27.04 & 1.62 & 9.82 & 15.58 & 12.46 & 3.50 & 10.00 & 5.00 \\
\hline June & 28.74 & 1.42 & 9.85 & 15.68 & 12.82 & 4.00 & 6.00 & 5.00 \\
\hline September & 29.25 & 1.62 & 10.17 & 15.92 & 13.14 & 5.00 & 10.00 & 6.00 \\
\hline December & 29.29 & 1.88 & 10.43 & 16.10 & 13.18 & 6.00 & 6.00 & 6.00 \\
\hline \multicolumn{9}{|l|}{1994} \\
\hline March & 27.35 & 2.02 & 10.35 & 15.75 & 13.60 & 6.00 & 10.00 & 8.00 \\
\hline
\end{tabular}

Sources: Bank of Lebanon; and Société Financière du Liban.

'End-of-period interest rates.

2Weighted average. 
Table A 14. Summary of the Balance of Payments

\begin{tabular}{|c|c|c|c|c|c|}
\hline & \multicolumn{5}{|c|}{ Estimates } \\
\hline & 1989 & 1990 & 1991 & 1992 & 1993 \\
\hline & \multicolumn{5}{|c|}{ (In millions of U.S. dollars) } \\
\hline Current account & -785 & $-1,351$ & $-2,935$ & $-3,053$ & $-3,417$ \\
\hline Trade balance & $-1,779$ & $-2,082$ & $-3,258$ & $-3,169$ & $-3,537$ \\
\hline Exports, f.o.bl & 484 & 496 & 490 & 601 & 686 \\
\hline Imports, f.o.bl & $-2,263$ & $-2,578$ & $-3,748$ & $-3,770$ & $-4,222$ \\
\hline Services & 514 & 451 & 143 & -84 & -181 \\
\hline Factor & 725 & 694 & 478 & 263 & 197 \\
\hline Interest earnings of the Bank of Lebanon & 71 & 39 & 32 & 14 & 26 \\
\hline Commercial banks' investment income ${ }^{2}$ & 199 & 168 & 136 & 111 & 106 \\
\hline Nonbank investment income ${ }^{3}$ & 456 & 487 & 310 & 138 & 88 \\
\hline Interest on external public debt & $\ldots$ & $\ldots$ & $\ldots$ & $\ldots$ & -24 \\
\hline Nonfactor & -211 & -243 & -335 & -347 & -377 \\
\hline Insurance and freight & -226 & -258 & -375 & -377 & -422 \\
\hline Travel and transportation & 15 & 15 & 40 & 30 & 45 \\
\hline Private transfers & 480 & 280 & 180 & 200 & 300 \\
\hline Capital account & 476 & 920 & 4,009 & 3,107 & 4,587 \\
\hline Direct investment & $\cdots$ & $\cdots$ & $\cdots$ & $\ldots$ & 902 \\
\hline Of which: SOLIDERE & - & - & - & - & 252 \\
\hline External public debt disbursements & $\cdots$ & $\cdots$ & $\cdots$ & ... & 126 \\
\hline Public sector grants & $\ldots$ & $\ldots$ & $\ldots$ & $\ldots$ & 30 \\
\hline Amortization on external public debt ${ }^{4}$ & -4 & - & - & -59 & -47 \\
\hline Nonbank short-term capital ${ }^{3}$ & -735 & $-1,017$ & 1,404 & 465 & 652 \\
\hline Claims on international banks & -833 & $-1,087$ & 1,692 & 490 & 601 \\
\hline Liabilities to international banks & 98 & 70 & -288 & -25 & 51 \\
\hline Other capital (including errors and omissions) 5 & 1,215 & 1,937 & 2,605 & 2,700 & 2,924 \\
\hline Overall balance & -309 & -431 & 1,074 & 54 & 1,170 \\
\hline Net foreign reserves (- increase) & 309 & 431 & $-1,074$ & -54 & $-1,170$ \\
\hline Bank of Lebanon & 43 & 297 & -569 & -231 & -456 \\
\hline \multirow[t]{2}{*}{ Commercial banks } & 266 & 134 & -505 & 177 & -713 \\
\hline & \multicolumn{5}{|c|}{ (In millions of U.S. dollars, unless otherwise indicated) } \\
\hline \multicolumn{6}{|l|}{ Memorandum items: } \\
\hline Current account balance/GDP (in percent) & -28.9 & -47.6 & -65.9 & -55.1 & -45.3 \\
\hline External public debt ${ }^{6}$ & 332.1 & 332.1 & 332.1 & 273.4 & 352.2 \\
\hline External public debt/GDP (in percent) & 12.2 & 11.7 & 7.5 & 4.9 & 4.7 \\
\hline Debt service & $\cdots$ & ... & $\cdots$ & $\cdots$ & 71.2 \\
\hline Debt service/current receipts (in percent) & $\ldots$ & $\ldots$ & $\ldots$ & $\ldots$ & 5.3 \\
\hline $\begin{array}{l}\text { Central bank foreign exchange reserves } \\
\text { Central bank foreign exchange reserves }\end{array}$ & 906.3 & 623.3 & $1,236.7$ & $1,448.0$ & $2,220.0$ \\
\hline (in months of imports) & 4.8 & 2.9 & 4.0 & 4.6 & 6.3 \\
\hline
\end{tabular}

Sources: Bank of Lebanon; Council for Development and Reconstruction; Ministry of Finance; IMF, Direction of Trode Stotistics and International Financial Stotistics; and IMF staff estimates.

IIMF, Direction of Trode Stotistics. Figures for 1993 were estimated using data for January-November of that year.

2Estimated by applying the average three-month Eurodollar rate, with appropriate margins, to the average in over each year.

${ }^{3}$ Data on the flow of international bank lending to nonbank residents of Lebanon and on the flow of deposits by residents with international banks are obtained from International Financial Stotistics, adjusted for variations in U.S. dollar/nondollar exchange rates. Estimates of interest payments and receipts relating to such international bank lending and deposit taking are derived by applying the average three-month Eurodollar rate, with appropriate margins. to the average stocks in each year.

4Figures for 1989-92 are net of disbursements.

SIncludes valuation adjustments.

6The authorities are in the process of revising external debt data for |989-9|. 
Table A 15. Composition of Industrial Exports (In percent of total)

\begin{tabular}{|c|c|c|c|c|c|}
\hline & 1989 & 1990 & 1991 & 1992 & 1993 \\
\hline Food and beverages & 11 & 10 & 13 & 6 & 21 \\
\hline Textiles & 23 & 18 & 15 & 14 & 17 \\
\hline Leather, plastics, and rubber & 3 & 4 & 3 & 3 & 5 \\
\hline Wood and wood products & 4 & I & 1 & 1 & - \\
\hline Chemicals and pharmaceuticals & 10 & 13 & 17 & 35 & 9 \\
\hline Paper and paper products & 7 & 9 & 10 & 6 & 5 \\
\hline Stone, clay, and glass & 6 & 5 & 4 & 6 & 5 \\
\hline Metal and metal products & 9 & 20 & 20 & 11 & 10 \\
\hline Machinery and appliances & 10 & 9 & 8 & 8 & 18 \\
\hline Jewelry & 16 & 6 & 6 & 3 & 9 \\
\hline Other & 2 & 5 & 3 & 7 & 1 \\
\hline Total & 100 & 100 & 100 & 100 & 100 \\
\hline
\end{tabular}

Sources: For 1989-92, Beirut Chamber of Commerce and Industry; for 1993, Lebanon Directorate of Customs.

Table A 16. Destination of Exports (In percent of total)

\begin{tabular}{|c|c|c|c|c|c|}
\hline & 1989 & 1990 & 1991 & 1992 & 1993 \\
\hline Industrial countries & 41.1 & 40.3 & 42.8 & 32.7 & 23.4 \\
\hline France & 4.9 & 5.0 & 5.9 & 5.3 & 6.0 \\
\hline Germany & 2.7 & 3.4 & 2.8 & 2.4 & 1.6 \\
\hline Italy & 6.9 & 9.0 & 5.7 & 3.0 & 0.9 \\
\hline Switzerland & 10.2 & 10.4 & 12.2 & 8.0 & 0.5 \\
\hline United Kingdom & 3.4 & 2.1 & 2.8 & 2.9 & 3.8 \\
\hline United States & 5.9 & 4.5 & 5.3 & 4.6 & 4.4 \\
\hline Other & 7.1 & 5.9 & 8.1 & 6.4 & 6.2 \\
\hline Developing countries & 58.9 & 59.7 & 57.2 & 67.3 & 76.6 \\
\hline Africa & 4.3 & 4.6 & 5.2 & 5.1 & 4.9 \\
\hline Europe & 2.0 & 4.4 & 7.4 & 6.8 & 14.6 \\
\hline Middle East & 51.5 & 48.8 & 43.3 & 54.5 & 53.9 \\
\hline Egypt & 2.5 & 2.7 & 3.5 & 3.2 & 2.5 \\
\hline Jordan & 2.2 & 3.0 & 5.8 & 7.2 & 5.7 \\
\hline Kuwait & 12.4 & 8.8 & - & - & 5.8 \\
\hline Saudi Arabia & 18.6 & 16.7 & 15.2 & 21.8 & 13.4 \\
\hline Syria & 1.2 & 3.1 & 5.2 & 6.3 & 11.7 \\
\hline Únited Arab Emirates & 10.3 & 9.9 & 9.0 & 10.6 & 9.0 \\
\hline Other & 4.2 & 4.6 & 4.7 & 5.4 & 5.8 \\
\hline Other & 1.0 & 2.0 & 1.2 & 0.9 & 3.3 \\
\hline Total & 100.0 & 100.0 & 100.0 & 100.0 & 100.0 \\
\hline
\end{tabular}

Sources: For 1989-92, IMF, Direction of Trade Statistics; for 1993, Lebanon Directorate of Customs. The DOT data for Lebanon are based on trading partner records and include estimates, particularly for exports to developing countries. 
Table A 17. Source of Imports

(in percent of total)

\begin{tabular}{|c|c|c|c|c|c|}
\hline & 1989 & 1990 & 1991 & 1992 & 1993 \\
\hline Industrial countries & 58.2 & 54.4 & 60.5 & 60.5 & 62.4 \\
\hline Belgium-Luxembourg & 3.8 & 3.1 & 3.8 & 3.1 & 1.8 \\
\hline France & 8.8 & 7.9 & 8.7 & 8.1 & 8.6 \\
\hline Germany & 7.8 & 5.9 & 6.7 & 6.8 & 9.3 \\
\hline Italy & 12.8 & 12.5 & 13.8 & 13.6 & 12.7 \\
\hline Japan & 3.4 & 3.8 & 3.2 & 3.6 & 3.9 \\
\hline Switzerland & 3.0 & 3.7 & 3.6 & 2.6 & 3.4 \\
\hline United Kingdom & 3.9 & 4.1 & 4.5 & 4.2 & 4.3 \\
\hline United States & 4.5 & 4.2 & 4.9 & 8.1 & 10.6 \\
\hline Other & 10.1 & 9.1 & 11.2 & 10.5 & 7.8 \\
\hline Developing countries & 41.8 & 45.6 & 39.5 & 39.5 & 37.6 \\
\hline Africa & 0.4 & 0.5 & 0.5 & 0.5 & 0.9 \\
\hline Europe & 16.7 & 15.3 & 11.5 & 11.3 & 14.5 \\
\hline Cyprus & 3.3 & 4.0 & 3.6 & 3.2 & 0.4 \\
\hline Romania & 3.1 & 3.8 & 1.7 & 3.0 & 1.5 \\
\hline Turkey & 3.7 & 2.2 & 1.8 & 1.3 & 1.6 \\
\hline Other & 6.5 & 5.3 & 4.4 & 3.8 & 11.0 \\
\hline Middle East & 12.1 & 16.6 & 14.7 & 14.3 & 10.3 \\
\hline Bahrain & 1.0 & 1.0 & 0.7 & 0.7 & 0.1 \\
\hline Kuwait & 2.1 & 1.1 & - & - & 0.2 \\
\hline Saudi Arabia & 0.9 & 1.3 & 1.0 & 0.7 & 1.4 \\
\hline Syria & 6.5 & 11.4 & 11.4 & 11.4 & 5.0 \\
\hline Other & 1.7 & 1.9 & 1.5 & 1.5 & 3.6 \\
\hline Other & 12.5 & 13.2 & 12.9 & 13.4 & 11.9 \\
\hline Total & 100.0 & 100.0 & 100.0 & 100.0 & 100.0 \\
\hline
\end{tabular}

Sources: For 1989-92, International Monetary Fund, Direction of Trade Stotistics; for 1993, Lebanon Directorate of Customs. The DOT data for Lebanon are based on trading partner records and include estimates, particularly for imports from developing countries. 
Table A 18. Exchange Rate of the Lebanese Pound'

\begin{tabular}{|c|c|c|c|c|}
\hline & \multirow{2}{*}{$\begin{array}{c}\text { Exchange Rate } \\
\text { (In Lebanese pounds } \\
\text { per U.S. dollar) }\end{array}$} & \multirow{2}{*}{$\begin{array}{l}\text { Change in } \\
\text { U.S. Dollarl } \\
\text { Lebanese Pound } \\
\text { Rate over } \\
\text { Previous Year } \\
\text { (In percent) }\end{array}$} & \multirow{2}{*}{ 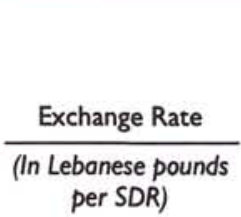 } & \multirow{2}{*}{$\begin{array}{c}\text { Change in } \\
\text { SDR/Lebanese } \\
\text { Pound } \\
\text { Rate over } \\
\text { Previous Year } \\
\text { (In percent) }\end{array}$} \\
\hline & & & & \\
\hline \multicolumn{5}{|l|}{1989} \\
\hline March & 495.0 & -26.6 & 639.9 & -21.2 \\
\hline June & 510.2 & -30.8 & 636.0 & -27.3 \\
\hline September & 468.0 & -11.3 & 599.0 & -10.6 \\
\hline December & 505.0 & 5.0 & 663.7 & 7.5 \\
\hline \multicolumn{5}{|l|}{1990} \\
\hline March & 571.0 & -13.3 & 742.8 & -13.9 \\
\hline June & 664.0 & -23.2 & 879.1 & -27.7 \\
\hline September & 930.0 & -49.7 & $1,295.1$ & -53.8 \\
\hline December & 842.0 & -40.0 & $1,197.9$ & -44.6 \\
\hline \multicolumn{5}{|l|}{1991} \\
\hline March & 938.0 & -39.1 & $1,262.8$ & -41.2 \\
\hline June & 904.5 & -26.6 & $1,189.0$ & -26.1 \\
\hline September & 891.5 & 4.3 & $1,219.6$ & 6.2 \\
\hline December & 879.0 & -4.2 & $1,257.3$ & -4.7 \\
\hline \multicolumn{5}{|l|}{1992} \\
\hline March & $1,280.0$ & -26.7 & $1,755.8$ & -28.1 \\
\hline June & $1,705.0$ & -47.0 & $2,440.1$ & -51.3 \\
\hline September & $2,420.0$ & -63.2 & $3,564.3$ & -65.8 \\
\hline December & $1,838.0$ & -52.2 & $2,527.3$ & -50.2 \\
\hline \multicolumn{5}{|l|}{1993} \\
\hline March & $1,742.0$ & -26.5 & $2,434.8$ & -27.9 \\
\hline June & $1,731.0$ & -1.5 & $2,429.6$ & 0.4 \\
\hline September & $1,723.5$ & 40.4 & $2,444.6$ & 45.8 \\
\hline December & $1,711.0$ & 7.4 & $2,350.2$ & 7.5 \\
\hline \multicolumn{5}{|l|}{1994} \\
\hline March & $1,694.5$ & 2.8 & $2,393.7$ & 1.7 \\
\hline
\end{tabular}

Source: IMF, International Financial Stotistics.

IAt end of period. 
Table A19. Nominal and Real Effective Exchange Rates of the Lebanese Pound (Index, 1989= 100; period averages)

\begin{tabular}{|c|c|c|}
\hline & $\begin{array}{c}\text { Nominal Effective } \\
\text { Exchange Ratel }\end{array}$ & $\begin{array}{l}\text { Real Effective } \\
\text { Exchange Ratel }\end{array}$ \\
\hline \multicolumn{3}{|l|}{1989} \\
\hline March & 103.06 & 90.97 \\
\hline June & 101.42 & 103.74 \\
\hline September & 100.94 & 109.37 \\
\hline December & 100.77 & 108.52 \\
\hline \multicolumn{3}{|l|}{1990} \\
\hline March & 84.16 & 107.52 \\
\hline June & 69.63 & 98.46 \\
\hline September & 40.92 & 95.77 \\
\hline December & 53.78 & 101.54 \\
\hline \multicolumn{3}{|l|}{1991} \\
\hline March & 45.29 & 108.14 \\
\hline June & 52.73 & 121.75 \\
\hline September & 51.82 & 117.88 \\
\hline December & 49.74 & 118.18 \\
\hline \multicolumn{3}{|l|}{1992} \\
\hline March & 38.89 & 142.39 \\
\hline June & 25.21 & 115.82 \\
\hline September & 16.58 & 114.90 \\
\hline December & 24.87 & 155.06 \\
\hline \multicolumn{3}{|l|}{1993} \\
\hline March & 27.44 & 167.62 \\
\hline June & 27.14 & 165.63 \\
\hline September & 27.40 & 167.17 \\
\hline December & 28.67 & 189.10 \\
\hline \multicolumn{3}{|l|}{1994} \\
\hline March & 28.53 & 190.85 \\
\hline
\end{tabular}

Source: IMF Information Notice System.

'Calculations based on U.S. dollars per Lebanese pound. 


\section{Bibliography}

Agénor, P. and M.S. Khan, "Foreign Currency Deposits and the Demand for Money in Developing Countries," IMF Working Paper 92/1 (Washington: International Monetary Fund, January 1992).

Arrau, P., and others, "The Demand for Money in Developing Countries: Assessing the Role of Financial Innovation," IMF Working Paper 91/45 (Washington: International Monetary Fund, April 1991).

Badrud-Din, A.-A., The Bank of Lebanon: Central Banking in a Financial Centre and Entrepôt (London: Frances Pinter, 1984).

Banerjee, A., and Juan J. Dolado, "Exploring Equilibrium Relationships in Econometrics Through Static Models: Some Monte Carlo Experience," Oxford Bulletin of Economics and Statistics, Vol. 48 (August 1986), pp. 253-77.

Banerjee, A., and others, Co-Integration, Error-Correction, and the Econometric Analysis of Non-Stationary Data (New York: Oxford University Press, 1993).

Barro, R.J., "Economic Growth in a Cross-Section of Countries," Quarterly Journal of Economics, Vol. 106 (May 1991), pp. 407-43.

, and X. Sala-i-Martin (1992a), "Convergence," Journal of Political Economy, Vol. 100 (1992), pp. 223-51.

(1992b), "Regional Growth and Migration: A JapanU.S. Comparison," Journal of the Japanese and International Economies, Vol. 6 (December 1992), pp. 312-46.

, Economic Growth, (New York: McGraw-Hill, 1994).

, N. Mankiw, and X. Sala-i-Martin, "Capital Mobility in Neoclassical Models of Growth," Economic Growth Center Discussion Paper No. 655 (New Haven, Conn.: Yale University, March 1992).

Bisat, A., and M. Hammour, "Economic Prospects for a Postwar Lebanon," in The Economics of Middle East Peace, ed. by S. Fischer, D. Rodrik, and E. Tuma (Cambridge, Massachusetts: MIT Press, 1993), pp. 155-79.

Bordo, M., and L. Jonung, The Long-Run Behavior of the Velocity of Money: The International Evidence (Cambridge: Cambridge University Press, 1987).

Bufman, G., and L. Leiderman, "Currency Substitution Under Nonexpected Utility: Some Empirical Evidence," Journal of Money, Credit and Banking, Vol. 25 (August 1993, Part 1), pp. 320-35.

Buiter, W., "A Guide to Public Sector Debt and Deficits," Economic Policy: A European Forum, Vol. 1 (November 1985), pp. 13-79.

Calvo, G.A., and C. Vegh, "Currency Substitution in Developing Countries: An Introduction," Revista de Analisis Economico, Vol. 7 (June 1992), pp. 3-27.
Cashin, P.A., "Economic Growth and Convergence Across the Seven Colonies of Australasia, 1861-1991," Economic Record (forthcoming, 1995).

Chami, S.N., "Economic Performance in a War-Economy: The Case of Lebanon," Canadian Journal of Development Studies, Vol. 13 (1992), pp. 325-36.

Cohen, D., "Growth, Productivity and Access to the World Financial Markets," Journal of the Japanese and International Economies, Vol. 6 (December 1992), pp. 365-82.

Coulombe, S., and F. Lee, "Regional Economic Disparities in Canada" (unpublished; Ottawa: University of Ottawa, 1993).

Dickey, David A., and Wayne A. Fuller, "Distribution of the Estimators for Autoregressive Time Series with a Unit Root," Journal of the American Statistical Association, Vol. 74 (June 1979), pp. 427-31.

"Likelihood Ratio Statistics for Autoregressive Time Series with a Unit Root," Econometrica, Vol. 49 (1981), pp. 1057-72.

El-Erian, M., "Currency Substitution in Egypt and the Yemen Arab Republic: A Comparative Quantitative Analysis," Staff Papers, International Monetary Fund, Vol. 35 (March 1988), pp. 85-103.

Elkahif, M.A., and A.A. Kubursi, "Currency Substitution and Exchange Rate Instability: Which Comes First?," QSEP Report No. 277 (Hamilton, Ontario: McMaster University, 1991).

Engle, R.F., and C.W.J. Granger, "Cointegration and Error Correction: Representation, Estimation, and Testing," Econometrica, Vol. 55 (March 1987), pp. 251-76.

Erbas, S. N., "The Limits on Bond Financing of Government Deficits Under Optimal Fiscal Policy," Journal of Macroeconomics, Vol. 11 (1989), pp. 589-98.

Ericsson, N.R., "Cointegration, Exogeneity, and Policy Analysis: An Overview," International Finance Discussion Paper No. 415 (Washington: Board of Governors of the Federal Reserve System, 1991).

Fischer, S., "Seigniorage and the Case for a National Money," Journal of Political Economy, Vol. 90 (April 1982), pp. 295-313.

Gaspard, Toufic, "The Gross Domestic Product of Lebanon in 1987," Bulletin Trimestriel, Banque du Liban, No. 40-43 (1989), pp. 5-12.

Girton, L., and D. Roper, "Theory and Implications of Currency Substitution," Journal of Money, Credit and Banking, Vol. 13 (1981), pp. 12-30.

Giovannini, A., and B. Turtelboom, "Currency Substitution," NBER Working Paper No. 4232 (Cambridge, Massachusetts: National Bureau of Economic Research, 1992). 
Giuidotti, P.E., and C.A. Rodriguez, "Dollarization in Latin America: Gresham's Law in Reverse?," Staff Papers, International Monetary Fund, Vol. 39 (September 1992), pp. 518-44.

Granger, C.W.J., "Developments in the Study of Cointegrated Economic Variables," Oxford Bulletin of Economics and Statistics, Vol. 48 (August 1986), pp. 213-28.

Hoffman, D.L., and C. Tahiri, "Money Demand in Morocco: Estimating Long-Run Elasticities for a Developing Country," Oxford Bulletin of Economics and Statistics, Vol. 56 (August 1994), pp. 305-24.

Horne, J., "Indicators of Fiscal Sustainability," IMF Working Paper 91/5 (Washington: International Monetary Fund, January 1991).

International Monetary Fund, International Financial Statistics (Washington: International Monetary Fund, various issues).

Direction of Trade Statistics (Washington: International Monetary Fund, various issues).

Johansen, S., "Statistical Analysis of Cointegrating Vectors," Journal of Economic Dynamics and Control, Vol. 12 (1988), pp. 231-54.

, and K. Juselius, "Maximum Likelihood Estimation and Inference on Cointegration, with Applications to the Demand for Money," Oxford Bulletin of Economics and Statistics, Vol. 52 (1990), pp. 169-210.

Khan, M., and C.L. Ramirez-Rojas, "Currency Substitution and Government Revenue from Inflation," Revista de Analisis Economico, Vol. 1 (1986), pp. 79-88.

Lipschitz, L., and D. McDonald, "Real Exchange Rates and Competitiveness: A Clarification of Concepts, and Some Measurements for Europe," IMF Working Paper 91/25 (Washington: International Monetary Fund, March 1991).

Lucas, R.E., "On the Mechanics of Economic Development," Journal of Monetary Economics, Vol. 22 (July 1988), pp. 3-42.

Makdisi, S., "Political Conflict and Economic Performance in Lebanon, 1975-1987," Bulletin Trimestriel, Banque du Liban, No. 33-34 (1987), pp. 4-12.

Marsh, I.W., and S.P. Tokarick, "Competitiveness Indictors: A Theoretical and Empirical Assessment," IMF Working Paper 94/29 (Washington: International Monetary Fund, March 1994).

McDermott, C.J., "Cointegration: Origins and Significance for Economists," New Zealand Economic Papers, Vol. 24 (1990), pp. 1-23. , and A. Y-T. Wong, "Exogeneity in the New Zealand Money-Income Relationship," New Zealand Economic Papers, Vol. 24 (1990), pp. 24-41.

Melvin, Michael, "The Dollarization of Latin America as a Market-Enforced Monetary Reform: Evidence and Implications," Economic Development and Cultural Change, Vol. 36 (April 1988), pp. 543-58.

, and G. A. de la Parra, "Dollar Currency in Latin America: A Bolivian Application," Economics Letters, Vol. 31 (December 1989), pp. 393-97.

Mulligan, C.B., and X. Sala-i-Martin, "Transitional Dynamics in Two-Sector Models of Endogenous Growth," Quarterly Journal of Economics, Vol. 108 (August 1993), pp. 739-73.

Muscatelli, V.A., and L. Papi, "Cointegration, Financial Innovation and Modelling the Demand for Money in Italy,"
Manchester School of Economic and Social Studies, Vol. 58 (September 1990), pp. 242-59.

Orden, D., and L.A. Fisher, "Financial Deregulation and the Dynamics of Money, Prices, and Output: Evidence from Australia and New Zealand," Discussion Paper No. 90/9 (Sydney, Australia: University of New South Wales, December 1990).

Osseiran, Fadi, "Currency Substitution in Lebanon, 1977-1986," Bulletin Trimestriel, Banque du Liban, No. 35 (1987), pp. 4-12.

Phillips, P.C.B., and S. Ouliaris, "Asymptotic Properties of Residual Based Tests for Cointegration," Econometrica, Vol. 58 (January 1990), pp. 165-93.

Phillips, P.C.B., and P. Perron, "Testing for a Unit Root in Time Series Regression," Biometrika, Vol. 75 (1988), pp. 335-46.

Saïdi, Nasser, "Flexible Exchange Rates and Competitive Banking: An Interpretation of Lebanon's Monetary Experience, 1950-1977," Bulletin Trimestriel, Banque du Liban, No. 9 (June 1981), pp. 28-40.

(1984a), "The Effects of the War on Economic Activity in Lebanon: Quantitative Estimates," Bulletin Trimestriel, Banque du Liban, No. 20 (1984), pp. 5-13. (1984b), "Explaining Inflation and the Depreciation of the Lebanese Pound: 1964-1982," Bulletin Trimestriel, Banque du Liban, No. 21-22 (1984).

"Economic Consequences of the War in Lebanon," Bulletin Trimestriel, Banque du Liban, No. 28-30 (1986).

Sala-i-Martin, X., "The Wealth of Regions: Evidence and Theories of Regional Growth and Convergence" (unpublished; New Haven, Conn.: Yale University, 1994).

Shioji, E., "Regional Growth in Japan," (unpublished; New Haven, Conn.: Yale University, 1992).

Short, B., "Preliminary Estimates of the Import Demand and Money Demand Functions," Bulletin Trimestriel, Banque du Liban, No. 10 (October 1981), pp. 24-26.

Solow, R.M., "A Contribution to the Theory of Economic Growth," Quarterly Journal of Economics, Vol. 70 (February 1956$)$, pp. 65-94.

Spitäller, Erich, "A Monetary Model of the Lebanese Pound/US Dollar Exchange Rate, 1952-1978," Bulletin Trimestriel, Banque du Liban, No. 6 (September 1980), pp. 42-47.

Stock, J.H., "Asymptotic Properties of Least Squares Estimators of Cointegrating Vectors," Econometrica, Vol. 55 (September 1987), pp. 1035-56.

Swan, T. W., "Economic Growth and Capital Accumulation," Economic Record, Vol. 32 (1956), pp. 334-61.

Toda, H.Y., and P.C.B. Phillips, "Vector Autoregressions and Causality,” Econometrica, Vol. 61 (November 1993), pp. 1367-93.

Towe, C.M., "Exchange Rate 'Fundamentals' Versus Speculation in a Developing Economy: An Illustrative Example Using Lebanese Data," Staff Papers, International Monetary Fund, Vol. 36 (September 1989), pp. 678-707.

United Nations, Special Economic and Disaster Relief Assistance: Special Programmes of Economic Assistance, Assistance for the Reconstruction and Development of Lebanon, A/46/557/Add.2 (New York: United Nations, 1991). 
Uzawa, Hirofumi, "Optimum Technical Change in an Aggregative Model of Economic Growth," International Economic Review, Vol. 6 (January 1965), pp. 18-31.

Vegh, C.A., "Currency Substitution and the Optimal Inflation Tax Under Labor Income Taxation" (unpublished; Washington: International Monetary Fund, 1989).

Wilson, John F., "Physical Currency Movements and Capital Flows," in Report on the Measurement of International
Capital Flows: Background Papers (Washington: International Monetary Fund, 1992), pp. 91-97.

Woodford, M., "Does Competition Between Currencies Lead to Price Level and Exchange Rate Stability?," NBER Working Paper No. 3441 (Cambridge, Massachusetts: National Bureau of Economic Research, 1990).

World Bank, Lebanon: Stabilization and Reconstruction, vols. 1 and 2 (Washington, 1993). 


\section{Recent Occasional Papers of the International Monetary Fund}

120. Economic Dislocation and Recovery in Lebanon, by Sena Eken, Paul Cashin, S. Nuri Erbaş, Jose Martelino, and Adnan Mazarei. 1995.

119. Singapore: A Case Study in Rapid Development, edited by Kenneth Bercuson with a staff team comprising Robert G. Carling, Aasim M. Husain, Thomas Rumbaugh, and Rachel van Elkan. 1995.

118. Sub-Saharan Africa: Growth, Savings, and Investment, by Michael T. Hadjimichael, Dhaneshwar Ghura, Martin Mühleisen, Roger Nord, and E. Murat Uçer. 1995.

117. Resilience and Growth Through Sustained Adjustment: The Moroccan Experience, by Saleh M. Nsouli, Sena Eken, Klaus Enders, Van-Can Thai, Jörg Decressin, and Filippo Cartiglia, with Janet Bungay. 1995.

116. Improving the International Monetary System: Constraints and Possibilities, by Michael Mussa, Morris Goldstein, Peter B. Clark, Donald J. Mathieson, and Tamim Bayoumi. 1994.

115. Exchange Rates and Economic Fundamentals: A Framework for Analysis, by Peter B. Clark, Leonardo Bartolini, Tamim Bayoumi, and Steven Symansky. 1994.

114. Economic Reform in China: A New Phase, by Wanda Tseng, Hoe Ee Khor, Kalpana Kochhar, Dubravko Mihaljek, and David Burton. 1994.

113. Poland: The Path to a Market Economy, by Liam P. Ebrill, Ajai Chopra, Charalambos Christofides, Paul Mylonas, Inci Otker, and Gerd Schwartz. 1994.

112. The Behavior of Non-Oil Commodity Prices, by Eduardo Borensztein, Mohsin S. Khan, Carmen M. Reinhart, and Peter Wickham. 1994.

111. The Russian Federation in Transition: External Developments, by Benedicte Vibe Christensen. 1994.

110. Limiting Central Bank Credit to the Government: Theory and Practice, by Carlo Cottarelli. 1993.

109. The Path to Convertibility and Growth: The Tunisian Experience, by Saleh M. Nsouli, Sena Eken, Paul Duran, Gerwin Bell, and Zühtü Yücelik. 1993.

108. Recent Experiences with Surges in Capital Inflows, by Susan Schadler, Maria Carkovic, Adam Bennett, and Robert Kahn. 1993.

107. China at the Threshold of a Market Economy, by Michael W. Bell, Hoe Ee Khor, and Kalpana Kochhar with Jun Ma, Simon N'guiamba, and Rajiv Lall. 1993.

106. Economic Adjustment in Low-Income Countries: Experience Under the Enhanced Structural Adjustment Facility, by Susan Schadler, Franek Rozwadowski, Siddharth Tiwari, and David O. Robinson. 1993.

105. The Structure and Operation of the World Gold Market, by Gary O'Callaghan. 1993.

104. Price Liberalization in Russia: Behavior of Prices, Household Incomes, and Consumption During the First Year, by Vincent Koen and Steven Phillips. 1993.

103. Liberalization of the Capital Account: Experiences and Issues, by Donald J. Mathieson and Liliana RojasSuárez. 1993.

102. Financial Sector Reforms and Exchange Arrangements in Eastern Europe. Part I: Financial Markets and Intermediation, by Guillermo A. Calvo and Manmohan S. Kumar. Part II: Exchange Arrangements of Previously Centrally Planned Economies, by Eduardo Borensztein and Paul R. Masson. 1993.

101. Spain: Converging with the European Community, by Michel Galy, Gonzalo Pastor, and Thierry Pujol. 1993.

100. The Gambia: Economic Adjustment in a Small Open Economy, by Michael T. Hadjimichael, Thomas Rumbaugh, and Eric Verreydt. 1992.

99. Mexico: The Strategy to Achieve Sustained Economic Growth, edited by Claudio Loser and Eliot Kalter. 1992.

98. Albania: From Isolation Toward Reform, by Mario I. Blejer, Mauro Mecagni, Ratna Sahay, Richard Hides, Barry Johnston, Piroska Nagy, and Roy Pepper. 1992.

97. Rules and Discretion in International Economic Policy, by Manuel Guitián. 1992.

96. Policy Issues in the Evolving International Monetary System, by Morris Goldstein, Peter Isard, Paul R. Masson, and Mark P. Taylor. 1992. 
95. The Fiscal Dimensions of Adjustment in Low-Income Countries, by Karim Nashashibi, Sanjeev Gupta, Claire Liuksila, Henri Lorie, and Walter Mahler. 1992.

94. Tax Harmonization in the European Community: Policy Issues and Analysis, edited by George Kopits. 1992.

93. Regional Trade Arrangements, by Augusto de la Torre and Margaret R. Kelly. 1992.

92. Stabilization and Structural Reform in the Czech and Slovak Federal Republic: First Stage, by Bijan B. Aghevli, Eduardo Borensztein, and Tessa van der Willigen. 1992.

91. Economic Policies for a New South Africa, edited by Desmond Lachman and Kenneth Bercuson with a staff team comprising Daudi Ballali, Robert Corker, Charalambos Christofides, and James Wein. 1992.

90. The Internationalization of Currencies: An Appraisal of the Japanese Yen, by George S. Tavlas and Yuzuru Ozeki. 1992.

89. The Romanian Economic Reform Program, by Dimitri G. Demekas and Mohsin S. Khan. 1991.

88. Value-Added Tax: Administrative and Policy Issues, edited by Alan A. Tait. 1991.

87. Financial Assistance from Arab Countries and Arab Regional Institutions, by Pierre van den Boogaerde. 1991.

86. Ghana: Adjustment and Growth, 1983-91, by Ishan Kapur, Michael T. Hadjimichael, Paul Hilbers, Jerald Schiff, and Philippe Szymczak. 1991.

85. Thailand: Adjusting to Success-Current Policy Issues, by David Robinson, Yangho Byeon, and Ranjit Teja with Wanda Tseng. 1991.

84. Financial Liberalization, Money Demand, and Monetary Policy in Asian Countries, by Wanda Tseng and Robert Corker. 1991.

83. Economic Reform in Hungary Since 1968, by Anthony R. Boote and Janos Somogyi. 1991.

82. Characteristics of a Successful Exchange Rate System, by Jacob A. Frenkel, Morris Goldstein, and Paul R. Masson. 1991.

81. Currency Convertibility and the Transformation of Centrally Planned Economies, by Joshua E. Greene and Peter Isard. 1991.

80. Domestic Public Debt of Externally Indebted Countries, by Pablo E. Guidotti and Manmohan S. Kumar. 1991.

79. The Mongolian People's Republic: Toward a Market Economy, by Elizabeth Milne, John Leimone, Franek Rozwadowski, and Padej Sukachevin. 1991.

78. Exchange Rate Policy in Developing Countries: Some Analytical Issues, by Bijan B. Aghevli, Mohsin S. Khan, and Peter J. Montiel. 1991.

77. Determinants and Systemic Consequences of International Capital Flows, by Morris Goldstein, Donald J. Mathieson, David Folkerts-Landau, Timothy Lane, J. Saúl Lizondo, and Liliana Rojas-Suárez. 1991.

76. China: Economic Reform and Macroeconomic Management, by Mario Blejer, David Burton, Steven Dunaway, and Gyorgy Szapary. 1991.

75. German Unification: Economic Issues, edited by Leslie Lipschitz and Donogh McDonald. 1990.

74. The Impact of the European Community's Internal Market on the EFTA, by Richard K. Abrams, Peter K. Cornelius, Per L. Hedfors, and Gunnar Tersman. 1990.

73. The European Monetary System: Developments and Perspectives, by Horst Ungerer, Jouko J. Hauvonen, Augusto Lopez-Claros, and Thomas Mayer. 1990.

72. The Czech and Slovak Federal Republic: An Economy in Transition, by Jim Prust and an IMF Staff Team. 1990.

71. MULTIMOD Mark II: A Revised and Extended Model, by Paul Masson, Steven Symansky, and Guy Meredith. 1990.

70. The Conduct of Monetary Policy in the Major Industrial Countries: Instruments and Operating Procedures, by Dallas S. Batten, Michael P. Blackwell, In-Su Kim, Simon E. Nocera, and Yuzuru Ozeki. 1990.

Note: For information on the title and availability of Occasional Papers not listed, please consult the IMF Publications Catalog or contact IMF Publication Services. 